د · مزة شبل محمد عـ

\title{
دور الإحالة
}

فى تعالق الخطاب السياسى بالخطاب السردى لواله

(سهام غير شاردة نموذجًا)

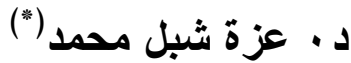

\section{المقدمة :}

تمنل الإحالة عنصرًا أساسيًّا من عناصر تماسك النصوص السردية،

وتنتخدم لأغر اض مختلفة نزجع لمقصدية الكاتب. وفى رواية (سهام غير شاردة) للأستاذ الدكتور حسن البندارى- التى جاءت طبعتها الأولى عام ـا • آم - برز دور الإحالة فى الربط بين عالمين من عو الم الخطاب، هما عالم الخطاب السردى الذى يمنل هيكل بناء الرواية ومظهرها الخارجى، و الآخر هو عالم الخطاب السياسى الذى يمنل العمود الفقرى للعمل الروائى وجوهره الداخلى بإحالاته على الأحداث التاريخية التى مرَّ بها المجتمع

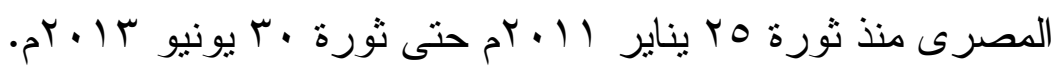

التعلق النصى:

اليعد مفهوم التعلق النصى نوعًا من أنواع المتعاليات النصية، ويعتبر هذا المفهوم نتاج العلاقة التى نربط بين نصين الأول لاحق و الثانى سابق، ويتخذ

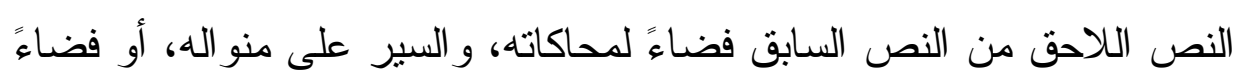
لمعارضته بشكل ساخر أو تحريفه، مدا يجعل العلاقة بينهما تعلقية.. ويتجاوز

(*) أستاذ اللغويات المساعد قسم اللغة العربية وآدابها كلية الآداب- جامعة القاهرة. 
التعلق النصى العلاقة بين نصين من النظام العلاماتى نفسه..إلى العلاقة بين

نصين من مصادر علاماتية مختلفة.«( ) ويعرِّ سعيد يقطين عملية التعلق النصى بأن القاعدة فيها اأن الكاتب من خلا قراءاته المتعددة، يتعلق بنص نموذج أو كاتب معين، ويظل يحتذيه، ويسير على منو اله فى نسج تجربته أو التتويع عليه.ب(؟)

وفى إطار هذا المفهوم، تحاول هذه الدر اسة الكثف عن التعالق فى رواية (سهام غير شاردة) بين الخطابين السردى و السياسى، على اعتبار أنه صورة من صور التفاعل النصى المتحقق بواسطة الروابط التى تسهّل عملية التفاعل بين القارى المؤوِّل وبنية النص.

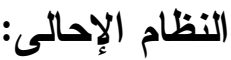

يؤدى النظام الإحالى داخل الرواية عدة وظائف تو اصلية تبعًا لمقصدية الكاتب، فالإحالة ليست أداة لغوية تزبط أجز اء النص فحسب، وتسهم فى تشكله

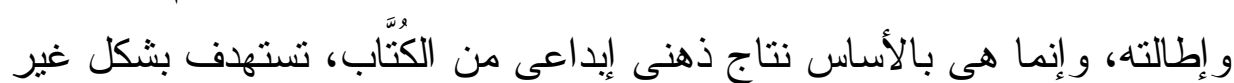
مباثر بناء تصور إدر اكى لدى الآخر؛ حيث تقوم الإحالة على مبدأ رئيسى هو مبدأ (التناسب)؛ أى نتاسب الإحالة التى ينشيئها المبدع مع المخزون المعرفى للإحالات فى وعى المتلقى. ومن ثن، فالإحالة عملية تو اصلية مشتركة بين كل من الكاتب و القارئ، تحقق وظائف تو اصلة متعددة، منها التعبير عن الأفكار أو المشاعر ، أو تقديم فكرة جديدة أو تأكيد فكرة ما أو دحضها، أو معارضتها، من

(1) محمد العنوز: تفاعل الأدب والتكنولوجيا، نصوص الو اقعية الرقمية لمحمد سناجلة

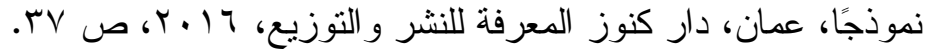

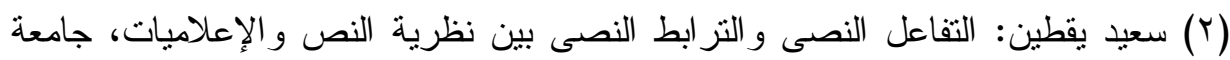

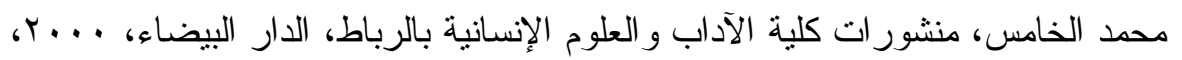




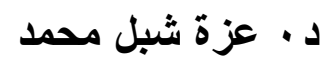

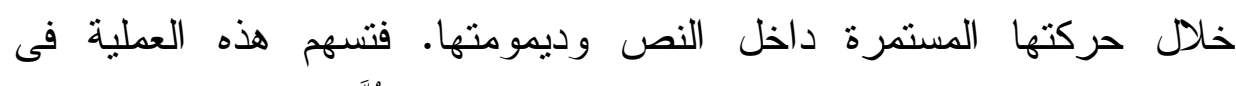
الخطابات الإبداعية فى تحقيق التقاعل بين تصور الكتّاب، و إدر الك المتلقين، على نحو تدريجى ومستمر، كما تسهم فى تشكيل الوعى التو اصلى بين أفراد المجتمع على نحو ما، وربما تؤدى إلى تغييره فى بعض الأحايين.

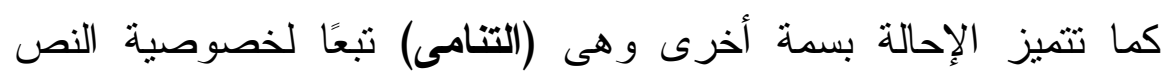
الرو ائى.فالإحالة ليست ثابتة، بل متغيرة، بما يكثف عن سمات الثخصية داخل

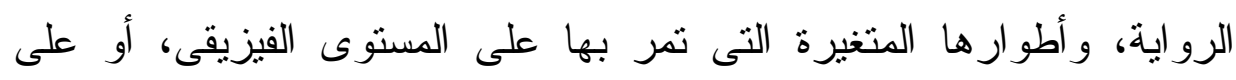
المستوى الفكرى، أو على المستوى الوجدانى.فتعدُّ الإحالة وسيلة بناء سردية؛

لإدخال معلومات جديدة عن المرجع/ المر اجع المستخدمة فى العمل الروائى. تهدف هذه الدراسة، مستعينة بمنهج تحليل الخطاب ونظرية علم لغة

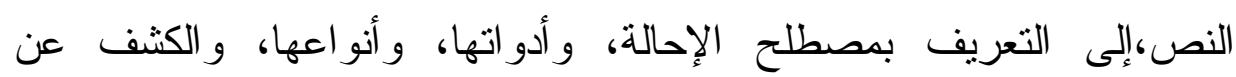
خصوصية الإحالة فى النص السردى الروائى، مع بيان دورها فى بناء كلا

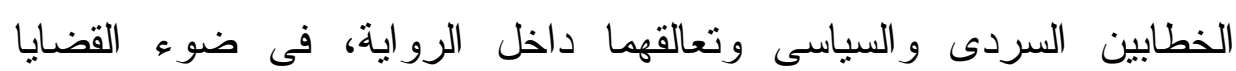
المطروحة و علاقتها بمقصدية الكاتب. لقد قدمت الدر اسات السابقة عن الإحالة منطلقات جيدة نحو توضيح مفهوم الإحالة، و أدو اتها، و أنواعها، و الكثف عن دورها النحوى الدلالى فى بناء تماسك النص وسيرورته، بدءًا بالدر اسة الر ائدة التى قدمها هاليداى ورقية حسن

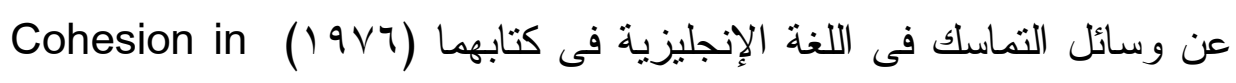
English أنماط الإحالة، ودور ها فى تز ابط النصوص. توصد ومن تلك الدراسات التطبيقية: الإحالة فى النص القرآنى، لياسين فوزى

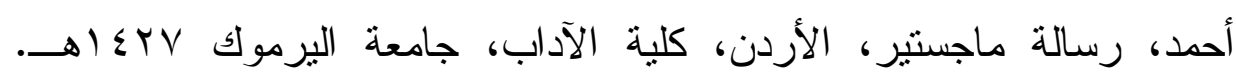
ودر اسة أخرى بعنوان: أنماط الإحالة فى القصص القرآنى، قصة موسى عليه السلام نموذجًا، لمليحة بنت محمد القحطانى، مجلة العلوم الثرعية و اللغة 


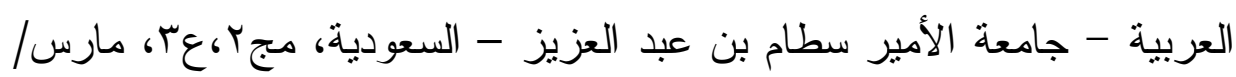

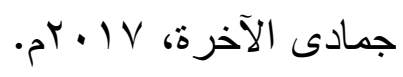

أما عن الدراسات التى تتاولت دور الإحالة فى النص الروائى، فلم نجد-

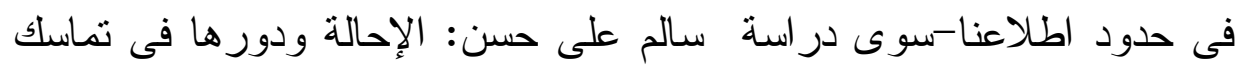
النص، رواية التبر للكونى نموذجًا، مجلة البحث العلمى فى الآداب بكلية البنات

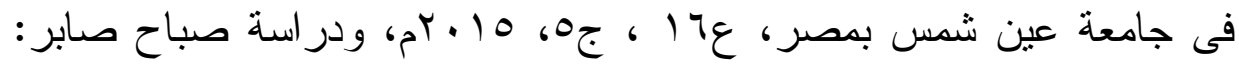

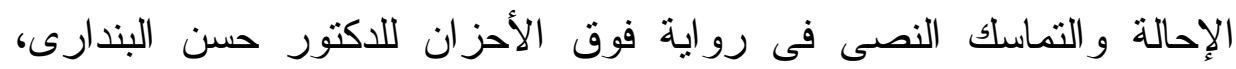

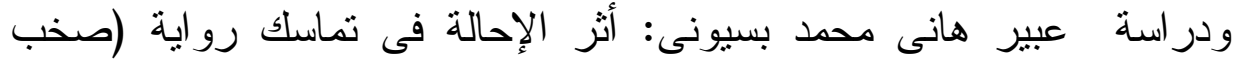

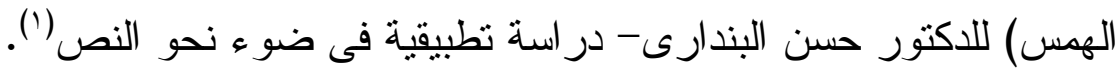

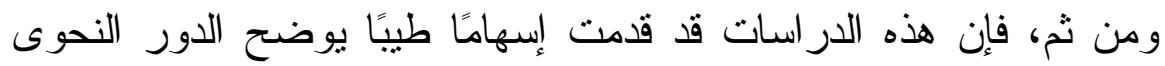
للإحالة فى الربط بين الجمل فى النصوص، ويظهر وسائل الإحالة المختلفة

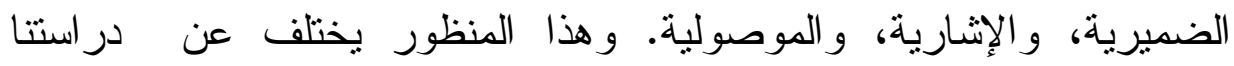

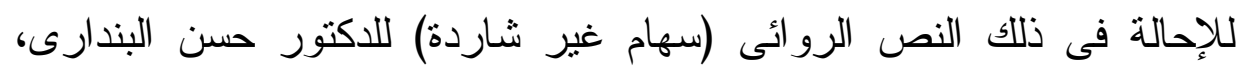
حيث تتميز هذه الرواية بكونها متعددة الخطابات؛ مما يجعل البحث فى دور

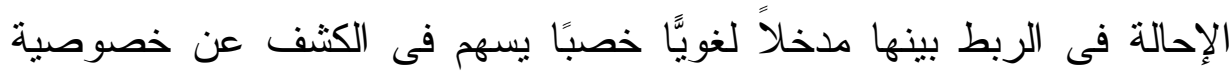
المكون الإحالى السردى، و أنماط الإحالة، ودور ها فى تعالق تلك الخطابات. وقد جاءت الدر اسة فى ثلاثة مباحث هى: $* *$

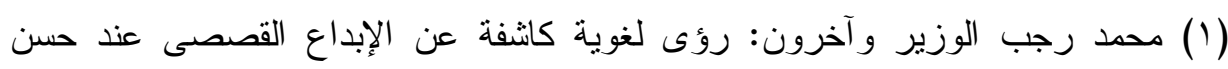

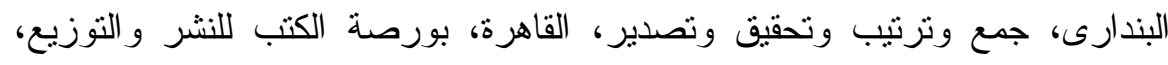




\section{المبحث الأول}

\section{التعريف بالمكون الإحالى فى النص السردى}

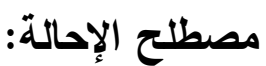

يقابل الإصطلح الإحالة فى المعجم الأجنبى لفظة reference التى تترجم

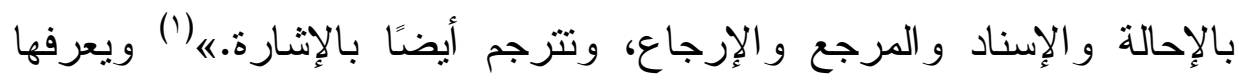

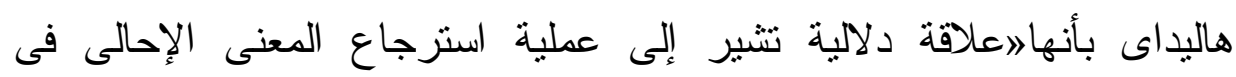

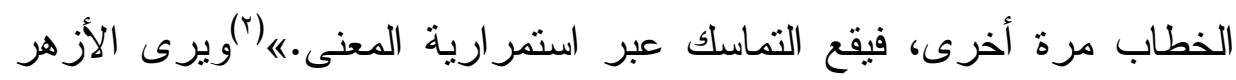

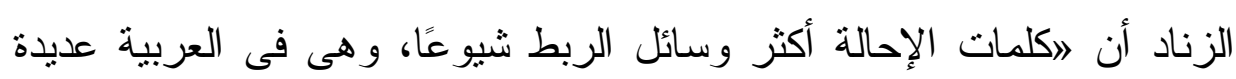

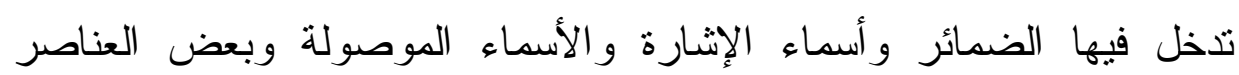

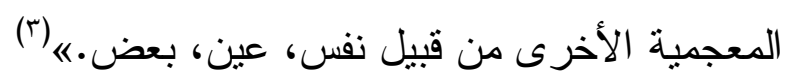
و إذا كانت نظرية النص النظرية مفسرة للاتصال اللغوى تعنى ببحث بعن إنتاج

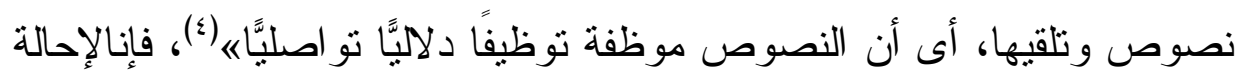

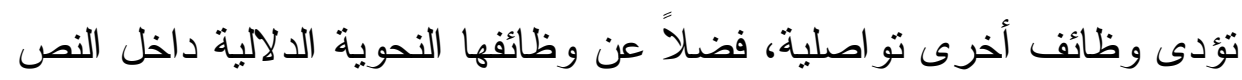

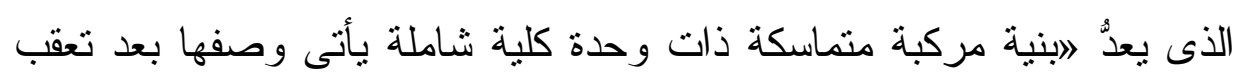

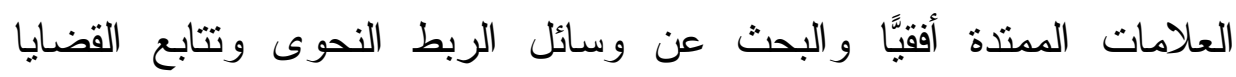
و المعلومات بالإضافة إلى التماسك ووسائله و الربط الداخلى بلى بين الأجزاء

(1) محمد الأمبنمصدق:الإحالة فى ضوء علم اللغة النصى، مجلة اللغة العربية -الجزائر،

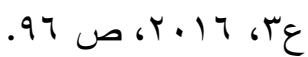

Halliday \& Hasan: Cohesion in English, London, Longman. $19 \vee 7$, p.r I.

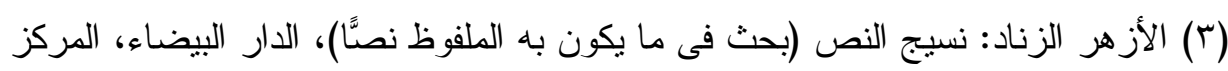

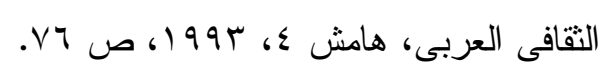

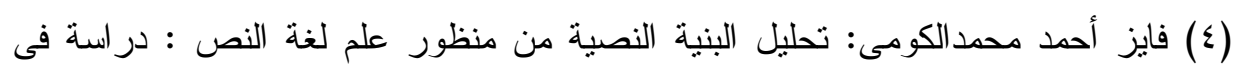

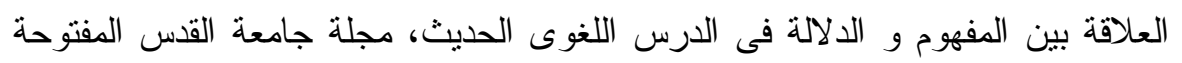

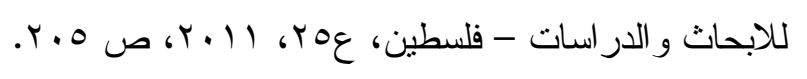


الصغرى. فالبنية النصية بنية معقدة ذات أبعاد أفقية وتدرج هرمى.《|('الإحالة

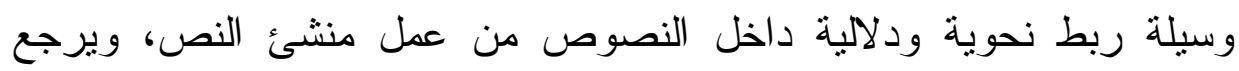

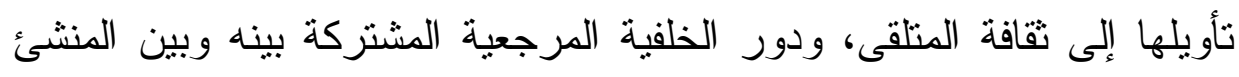

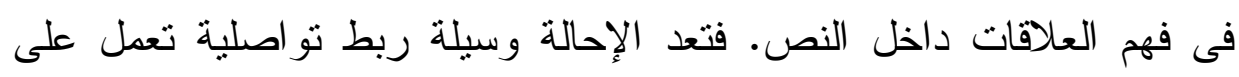
محورى إنتاج النص وتلقيه. التصور الذهنى للإحالة( المرجع الروائى غير الإحالى):

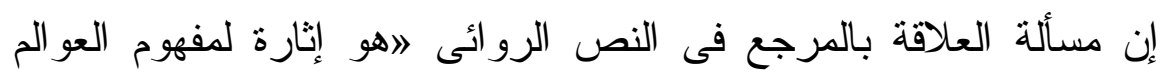

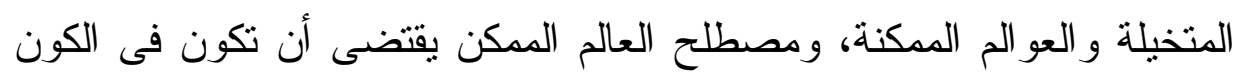

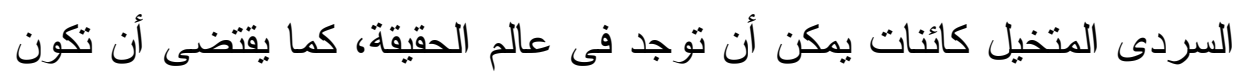
الأعمال التى تقوم بها الثخصيات منتظمة فى منطق شبيه بالمنطق الذى بنى بنتظم

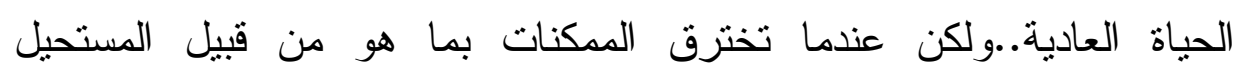
و الخارق، يفترق العالم المتخيل عن العالم المكن، منلما هو الحال وبدرجة

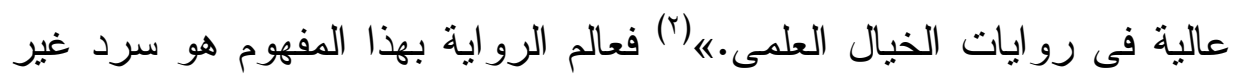

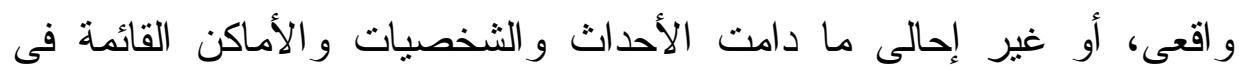

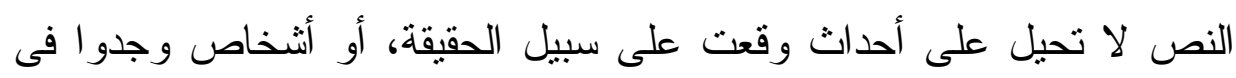

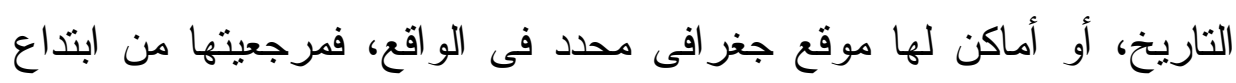

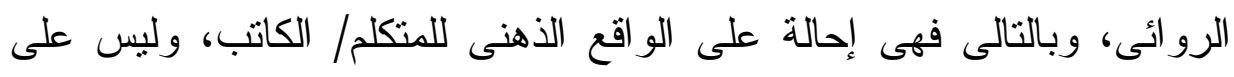

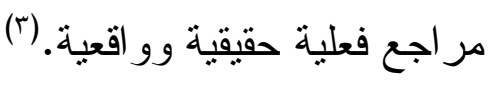

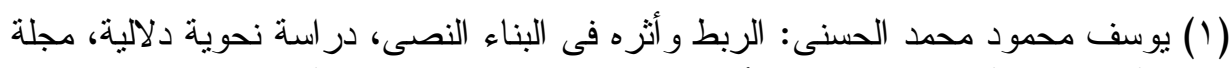

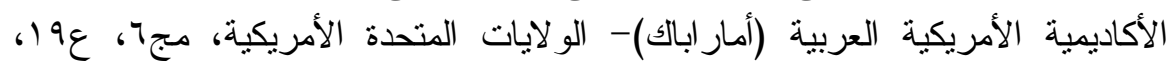

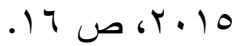

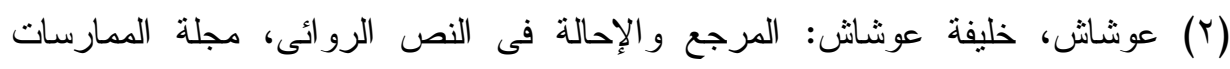

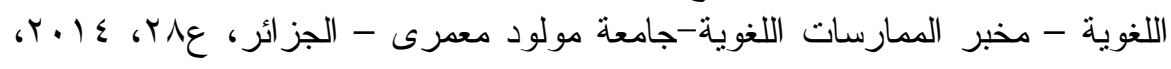


د.

وينى المتلقون الدلالة من خلال تلك التصورات الذهنية المختزنة عن عوالم حقيقية لذلك الفضاء المتخيل الذى تعمل فيه الثخصيات، وتصنع الأحداث. لاوقد يفسر هذا جانبًا من الحيوية و التجدد اللذين تتصف بهما؛ لأنها لم تقرن نفسها بحقيقة مطلقة، فتمثيلها المتتوع للعالم و الذى لا يخضع لمعايير ثابتة جعلها نوعًا سرديًا حيَّا يتبادل اسنشفافات لا نهائية مع المغذيات المحيطة به، سو اء أكانت مرجعيات حقيقية كالوقائع والأحداث أم ثقافية كالأنظمة الفكرية و العقائدية و الأخلاقية والاجتماعية، وأقامت رهانات على العلاقات التفاعلية و التواصلية بين العوالم الخارجية والعوالم النصية على سبيل التمثيل السردى.《) (1) الترميز الأهنى للإحالة فى العالم السردى: وفقًا لعلم العلامات، و العلاقة بين الدال و المدلول والمرجع الخارجى، فإن كلمات اللغة المادية تشير إلى مرجعية موجودة فى العالم الخارجى، يمكن إدر اكها بالحو اس، و على نحو مشابه، فإن الإحالات المعنوية المجردة قد تكونت مرجعيتها ودلالاتها الأساسية فى ذهن مستخدمى اللغة بفضل تعدد السياقات الواردة فيها، فى حين أن المراجع المستخدمة فى العالم الروائى سواء لهئه للشخصيات أو المكان أو الزمان لا وجود لها خارجيًّا، فهى رموز يعاد بناؤها فى ذهن المتلقى، وليس لها مرجعية حقيقية فى العالم الخارجى، و إنما تعتمد فى بناء مرجعيتها على عملية التمثيل الذهنى لها، ليس فى العو الم الفعلية، و إنما فى العو الم المحتملة أو الممكنة، التى يمكن تصور ها، دون أن يكون هنالك ربط مباثر بين الرموز الإحالية المستخدمة والعالم الخارجى. وينجح الكاتب عبر عمليات التكرار الإحالية، فى نتيثت تخزين التمثيل الدلالى للبنية التصورية 
الإحالية عن المراجع الروائية المستخدمة، فتصير مألوفة لدى المتلقى عبر الإله تكرار السياقات، شأنها فى ذللك شأن الإحالات اللغوية.

من المرجع اللغوى إلى المرجع التداولى (دلالة المرجع فى التركيب):

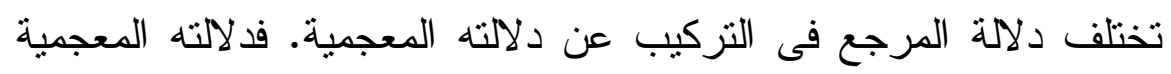
هى دلالة اصطلاحية يتفق عليها أبناء الجماعة اللغوية الواحدة، مثل مفردات اللغة الواردة فى المعجم. ولكن الأمر يختلف حال وقوع المرجع فئاء لجماعة نركيب؛ حيث يكتسب المرجع دلالة أخرى تعكس مقاصد منتج النص، و الصورة الذهنية

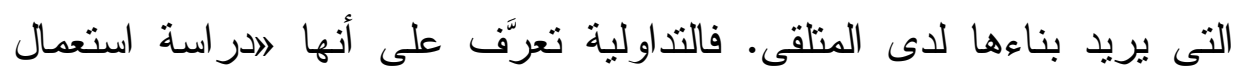

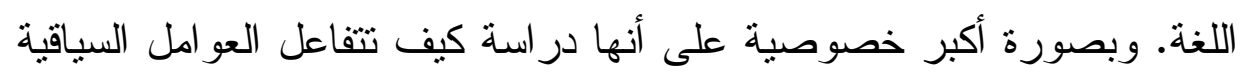

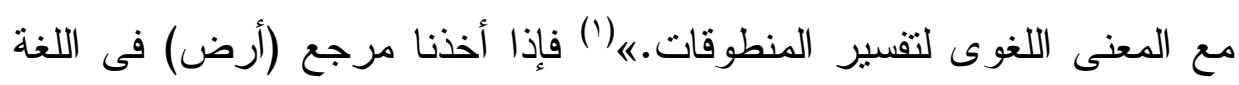

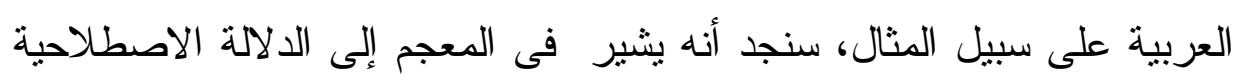

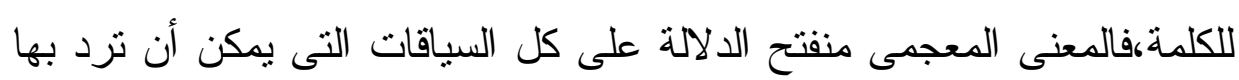

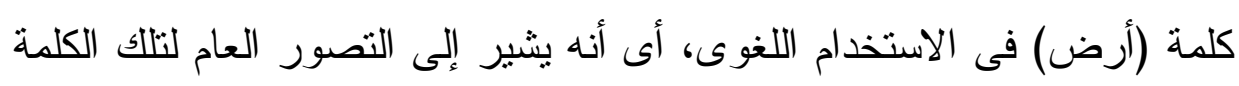

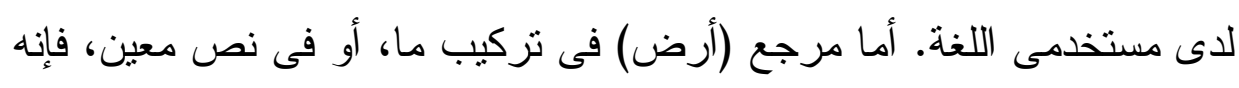

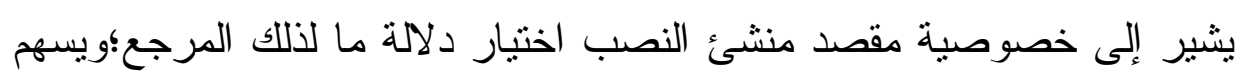

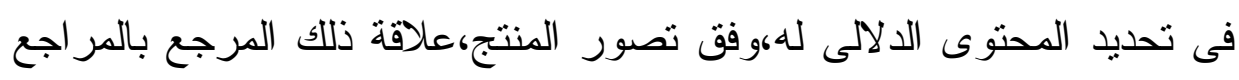
الأخرى المستخدمة فى النص،ثلاك الدلالة التى يسعى المتلقى إلى إعادة بنائها

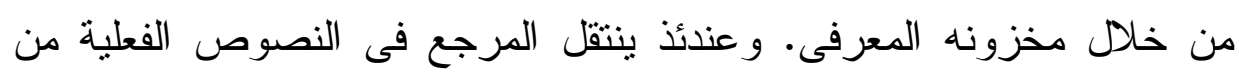

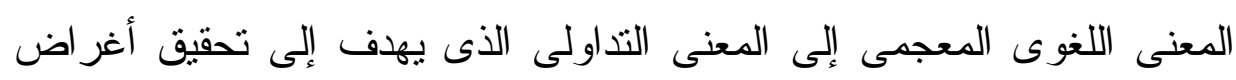
نو اصلية.

() حافظ إسماعلى علوى وآخرون: نساؤلات التداولية وتحليل الخطاب، ترجمة وتتسيق،

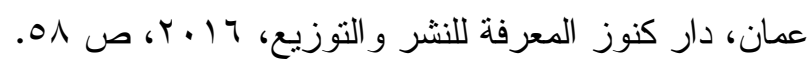




\section{د · مزة شبل محمد}

وفى عملية التحويل الدلالى للمرجع من المعنى اللغوى الاصطلاحى إلى المعنى التداولى الذى يقصده المتكلم/ الكاتب ويتمثله السامع/ القارئ، أثثاء عملية التلقى، تبرز أهمية السياق فى الكثف عن التفاعل بين مقاصد الخطاب ومقاصد منتجه، ومقبولية المتلقى. و عندئذ، فإن أى استبدال لمكون من مكونات الإحالة التداولية سيؤدى بالضرورة إلى اختلاف الدلالة الإحالية. مكون الإحالة التداولية (الوحدة الإحالية السردية الصغزى والنسيج

تتميز الإحالة فى الأعمال السردية بكونها ليست إحالة مفردة تشير إلى مرجع بسيطsimple reference، كأن نقول رجل أو امرأة، أو بيت، و إنما هى الإهى وحدة إحالية مركبة تتكون من عنصرين أساسيين يمكن أن نطلق على العنصر الأول مصطلح (البؤرة أو النواة)، والعنصر الآخر هو (الإطار الإحالى)، ويشكل كلا الجز أين وحدة إحالية سردية داخل العمل الروائى.

فتتشكل الوحدة الإحالية الصغزى فى الرواية من عنصرين هما: بؤرة الإحالة (النواة أو المركز)، مثل أسماء الشخصيات: (جمال المنصورى)، و أخيه (حازم المنصورى)، وزوجة جمال المنصورى وهى (مراجل الجابرى)، ومديرة مكتبه (أنوار المواردى)، ومديرة منزله (صفية). هذه المر اجع تجعل الإحالة الروائية مألوفة لاى المتلقى؛ لأنها تتلاقى مع المخزون المعرفى لدى القارئ من خلال المعرفة المشتركة بينهما بهذه الأسماء المعتاد استخدام ما يشبهـا فى العالم الخارجى. أما الجزء الآخر من مكون الإحالة فهو مايمكن أن نطلق عليه (الإطار الإحالى)، ونعنى به (المعلومات المقدَّمة التى تؤطر ذلك المرجع، تلك المعلومات تتو الى فى النص على شكل دفقات، مع كل ورود

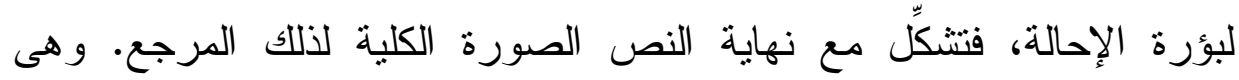
بالضرورة صورة مخصوصة تختلف من عمل إلى عمل.ومن مجموع جزأى 
المكون الإحالة ( البؤرة)، و (الإطار الإحالى) نتكون الوحدة الإحالية السردية

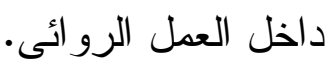

ففى المقطع السردى التالى: التردد صوت شقيقى جمال المنصورى..

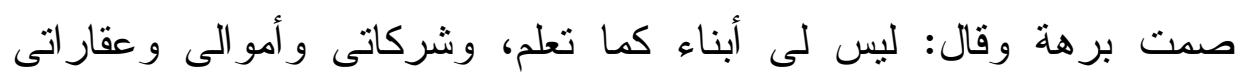

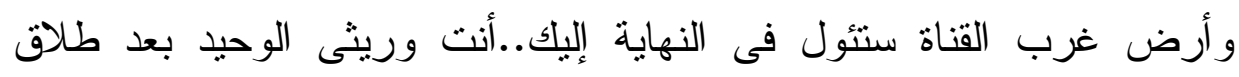

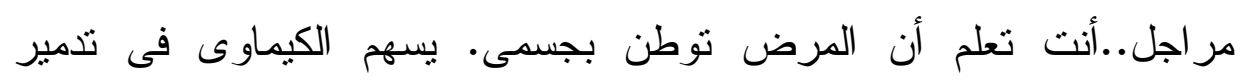

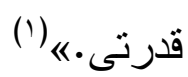

نجد أن هذه الوحدة الإحالية الصغرى تتكون من مرجع يمثل بؤزة الإحالة

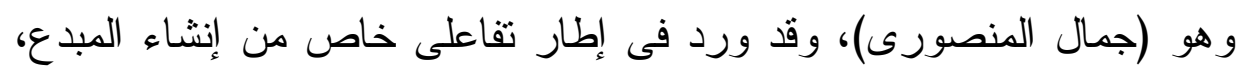

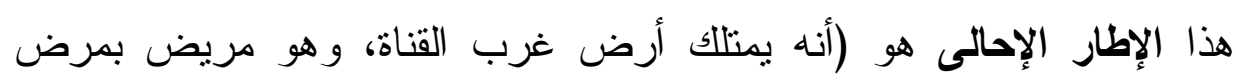

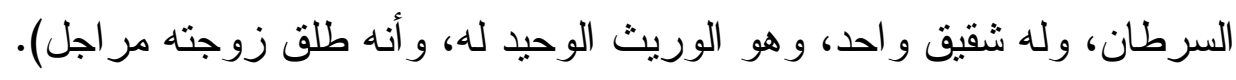

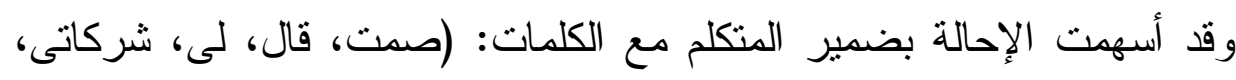
أمو الى، عقار اتى، وريثى، جسمى، قدرتى) فى بناء تلاك الوحدة الإحالية.

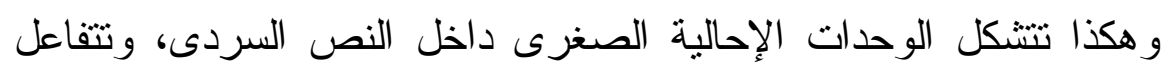

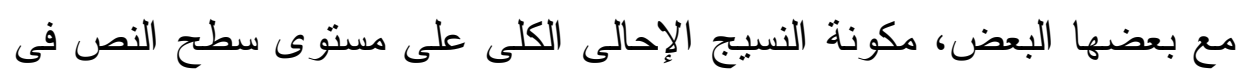

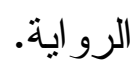

\section{التراتب الإحالى التداولى وبناء العنصر اللردى:}

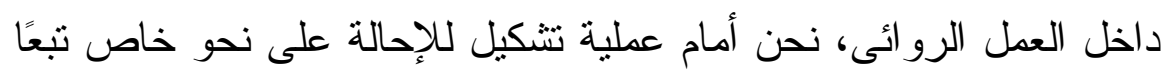

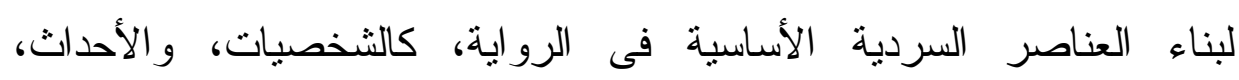

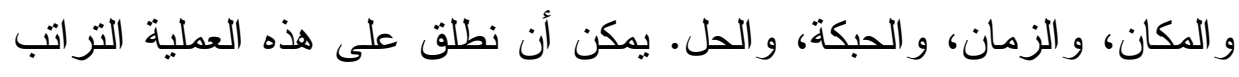

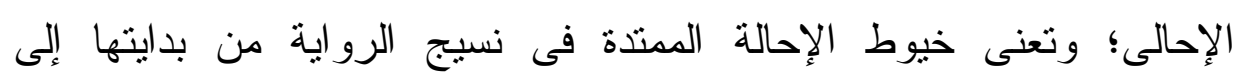

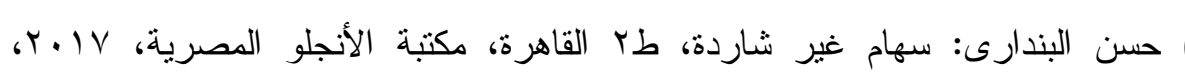

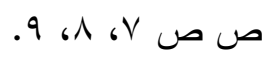




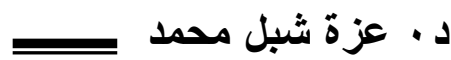

نهايتها،و المعلومات المقدمة مع كل تو ارد إحالى جديد على المرجع ذاته، ودلالة ترتيب المعلومات الإحالية المقدمة فى الرواية وفق الوظيفة التداولية التى يريد الكاتب إيصالها إلى المتلقى. لزعلى

ويمكننا التمثيل لعملية تر اتب الإحالة ودور ها فى بناء الثخصية من خلا له

تتبع الإحالة على مرجع (حازم المنصورى). فنجد الظهور الأول للإحالة يعرِّف

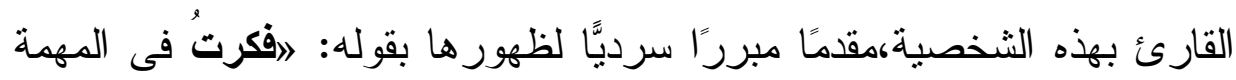
التى كلقنى بها شقيقى الأكبر جمال المنصورى"(')، ثم تقدم الإحالة التالية إلى هـى ذلك المرجع معلومة جديدة، وهى أنه كان خارج البلاد لمدة طويلة، من خلاله

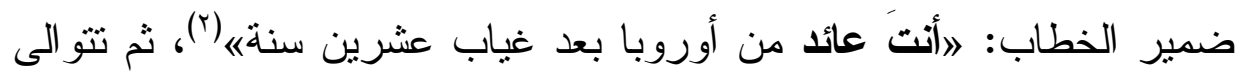
الإحالات فى الرواية، ومع كل ورود لها تقدم معلومة جديدة عن ذلك المرجع توضح دراسته، ومنصبه، وتكثن أيضًا عن علاقته الاجتماعية بأخيه، وأنه وريثه الوحيد، وهو مبرر سردى؛ لعدم ظهور إحالات أخرى لباقى أفراد

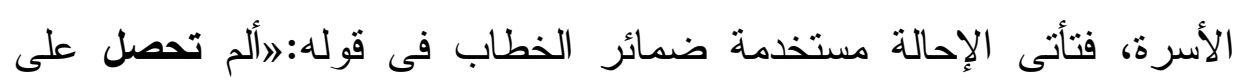

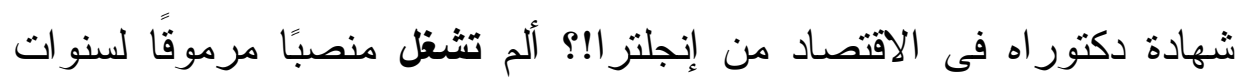
طويلة فى فرع المفوضية الاقتصادية الأوروبية بلندن .أتث وريثى منئ الوحيد.ب(ז)ث تكثف الإحالة عن علاقة ذلك المرجع بزوجة أخيه (مراجل)، بقوله 》صدَّقتُ أنَّها ترانى كأخ وصديق تحتاج إليه بين الحين والآخر . لكنتى جفلت من إحساس نام بأنها تجاوزت الحب الأخوى.《(گ)وتقدم الإحالة فى مقطع سردى آخر علاقة ذلك المرجع بأسرته وخوفه عليها من الخطر الذى يهددهم إذا لم يو افق على المشروع، مستخدمةً ضمائر المتكلم:اقررثُ قطع الإجازة

$$
\begin{aligned}
& \text { (1) حسن البندارى: سهام غير شاردة، ص } 7 .
\end{aligned}
$$

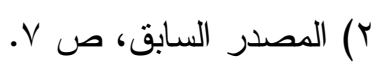

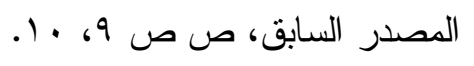

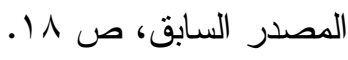




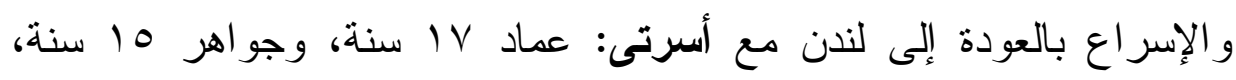

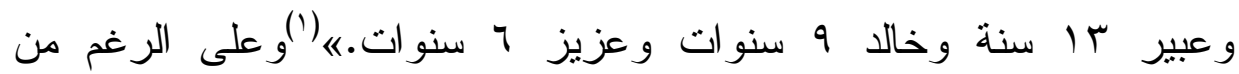
الضغوط و التهديدات، و عمليات القتل و التصفية على مدار الرو اية، ينتهى الخيط

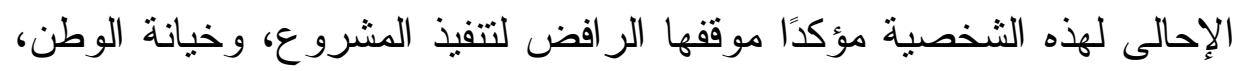

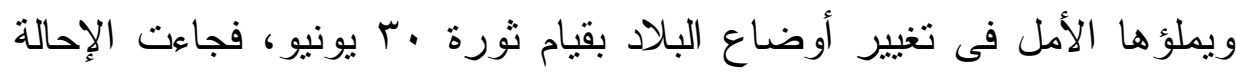

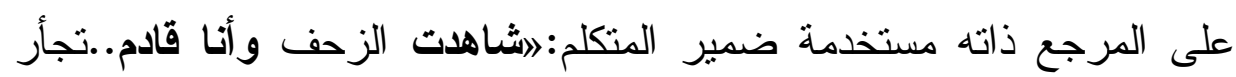

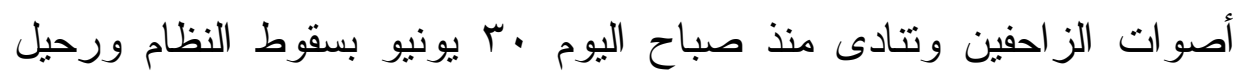

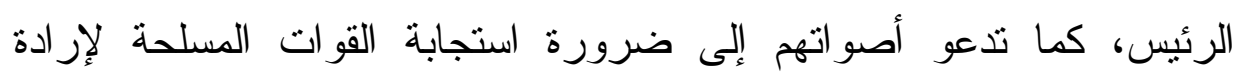

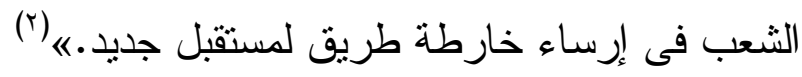

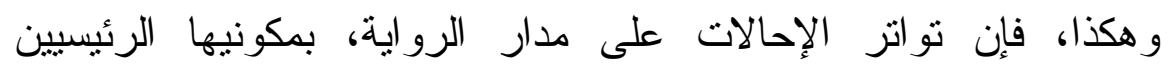

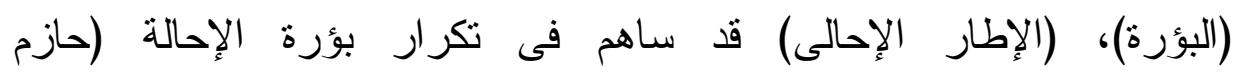

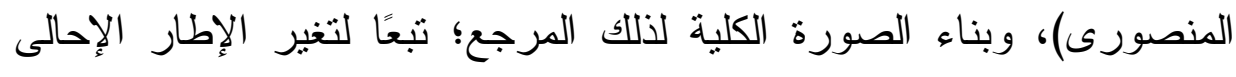

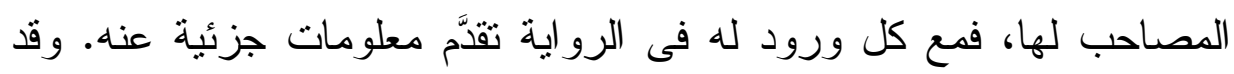

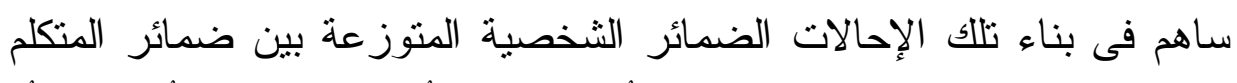

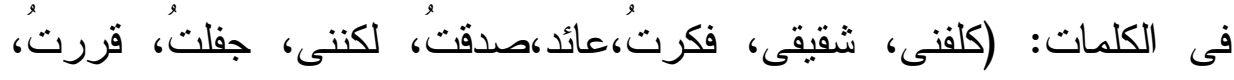

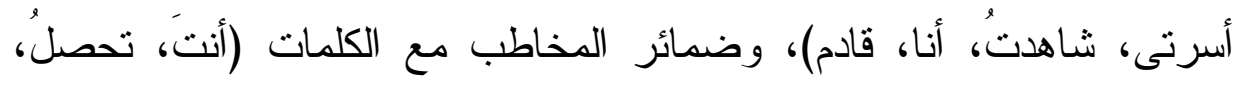

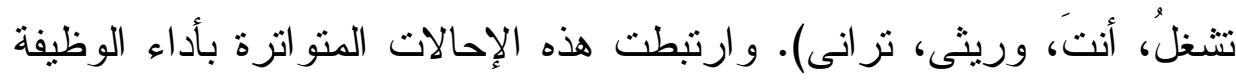

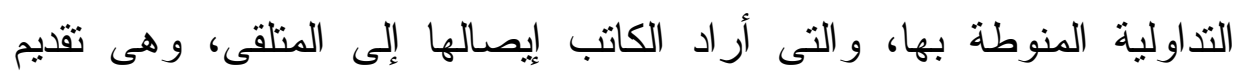

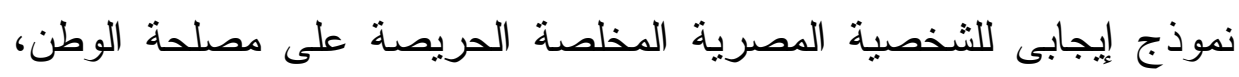
و الر افضة لخيانته، على الرغم من كثرة التهايدات التى تعرضت لهيه لها على مدار الأحداث فى الرو اية.

(1) حسن البندارى: سهام غير شاردة، ص 1 ا.

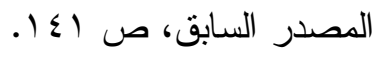


د. عزة شبل محمد بـ

الإحالة الرئيسة والإحالات المنسئة فى النسيج الإحالى:

يتكون النسيج الإحالى فى رواية (سهام غير شاردة) من إحالة رئيسة جسدتها الإحالة على شخصية الراوى (حازم المنصورى) التى امتذ ظهور ها منذ أول الحكى وحتى نهايته؛ لتصنع الخيط الأساسى للنسيج الإحالى فى الرواية. وقد انسل عن هذه الإحالة إحالات أخرى ذات علاقة بها. فجاءت الإحالات المنسلَّة ذات العلاقة بمحيط العمل، منمثلة فى مرجع (أنوار المواردى) سكرتيرة الثركة، و (سعفان الفرجانى) المهندس بالثركة، وعلى المستوى الاجتماعى فى محيط الأسرة، جاءت الإحالة على مرجع الزوجة(غدير)، و الأولاد (عماد، وجو اهر، و وعبير، وخالد، وعزيز)، و الأخ الأخ المهندس (جمال المنصورى)، وزوجة الأخ (مر اجل الجابرى)، وعلى المستوى

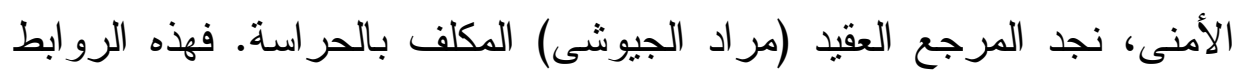
الاجتماعية المقدَّة داخل العمل الأدبى تخلق فى ذهن المتلقى تمثيلاً دلاليَّا للعلاقات الاجتماعية التى قد توجد بالفعل فى العالم الواقعى، وهذا ما يجعل عملية التلقى أكثر ألفة ومقبولية. وفى نسيج النص تصبح هذه التقنية التى يستخدمها الكتاب وسيلة أساسية من وسائل لحمة النص، يمكن لنا التمثيل لها بأكثر من نموذج دال داخل الرواية. فنسيج الإحالات التداولية فى الخطاب السردى يسمح بوجود تلك الإحالات المنسلة ذات العلاقة بالإحالة الرئيسة، ومن مجموع الإحالة الرئيسة، و الإحالات المنسئة تنشكل شبكة الإحالات فى السرد الروائى.

وتسهم هذه الإحالات المنسئة إلى الثخصيات غير الرئيسية فى بناء الفكرة الأساسية للرواية، فتتحول عبر تعدد الأصوات المنادية بها من فكرة فردية خاصة بشخصية ما داخل العمل الروائى إلى فكرة جمعية عامة نتبناها الأصو ات الإحالية، فيدعم ذلك مشروعيتها لدى المتلقى، وتزداد مقبوليته لها، 
على نحو تعمل الإحالة المنسلَّة إلى المرجع(أبناء حازم المنصورى)، فهم

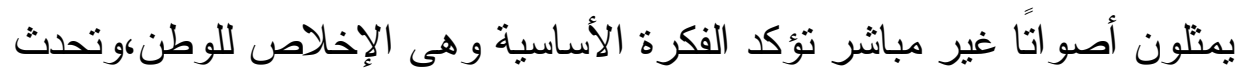

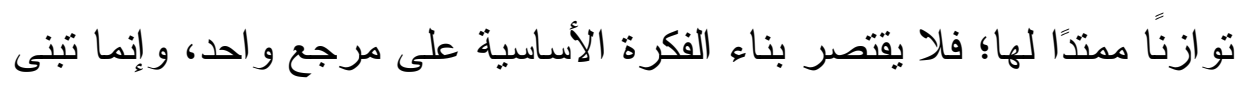

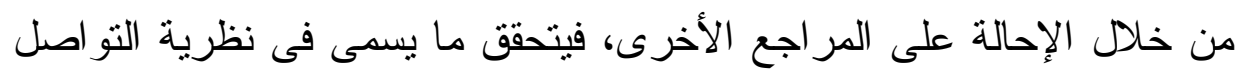

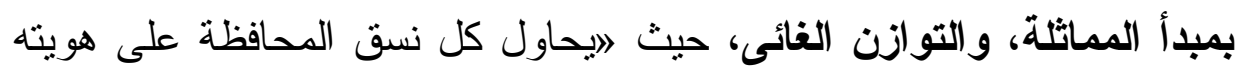

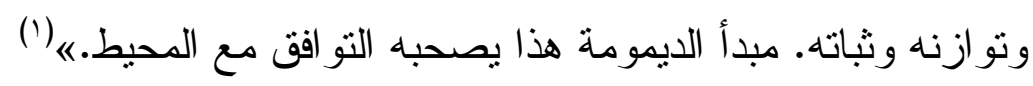
فنجد الكاتب ينقل الخطاب الروائى إلى الإحالة على مراجع (الأبناء)

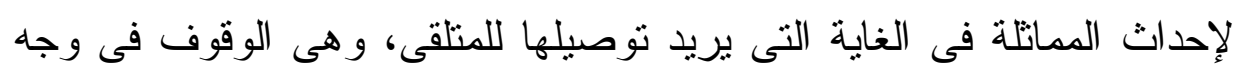

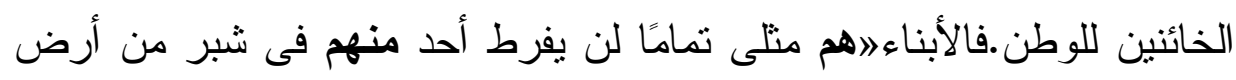

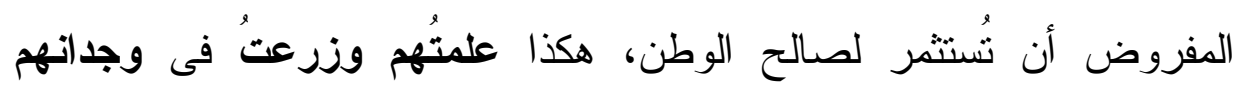

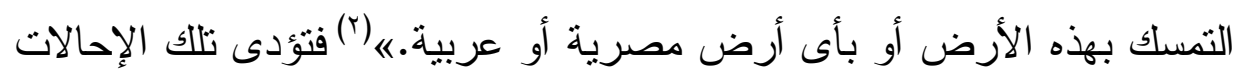

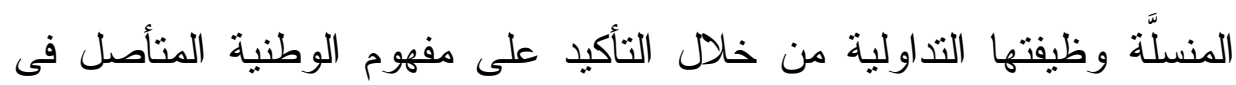
عقل ووجدان الأبناء، للتمسك بأى أرض مصرية أو عربية. إن النص الروائى عملية نو اصل بين المبدع و المتلقى، فكلاهما شريك فى الألى

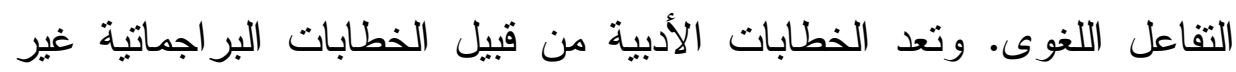

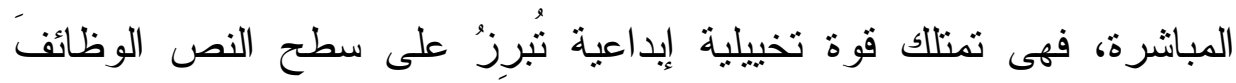

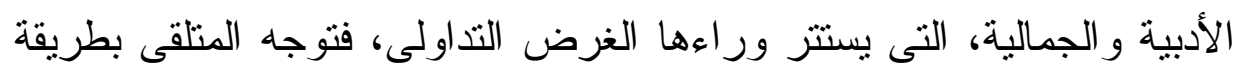

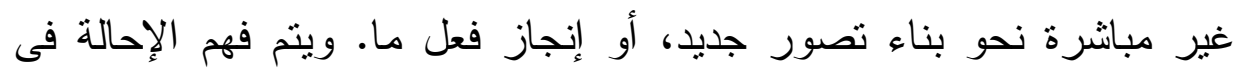

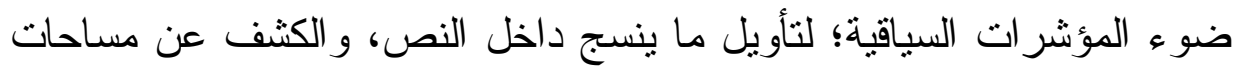

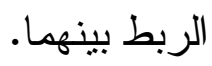

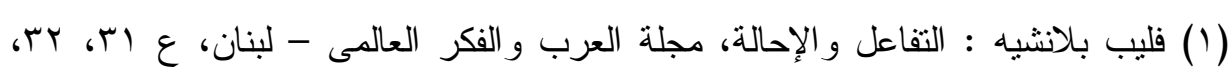

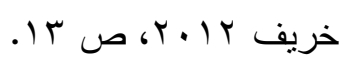$$
\text { (r) حسن البندارى: سهام غير شاردة، ص } 99 .
$$ 


\section{المبحث الثانى}

\section{أنماط الإحالة فى رواية سهام غير شاردة}

تشير الار اسات النظرية إلى أن الإحالة تتقسم إلى نوعين أساسيين:

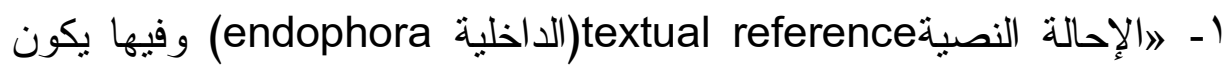
العنصر المشار إليه موجود داخل النص."(')، أو هى إحالة على العناصر الو اردة فى الملفوظ(؟). و وتتقسم إلى نوعين:

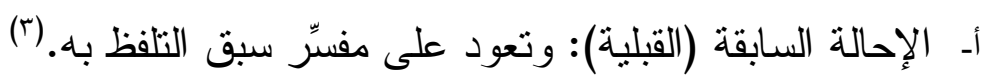
بـ الإحالة اللاحقة (البعدية): وتعود على عنصر إثنارى مذكور بعدها فى الإحى النص، لاحق عليها.(؟) r- الإحالة المقامية Situational reference(الخارجية exophora) وتشير. إلى مشار إليه محدد فى سياق الموقف(ْ). وهذا النوع من الإحالة يتوقف

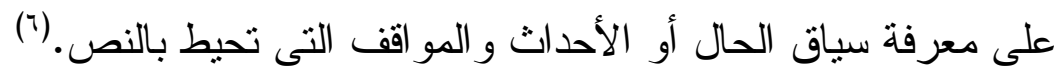
سوف تتطلق در استتا لأنواع الإحالة من تلك التقسيمات، محاولةً الكثف التف عن خصوصية الإحالة فى النص السردى الروائى. شبكة الإحالات الداخلية وخيوط ربط العناصر السردية: الإحالة الأفقية (الخطية) والإحالة الرأسية (الإحالة الومضة): يتميز النوع الروائى بوجود نوعين من الإحالات. النوع الأول هو الإحالات الخطية، أو الإحالات الأفقية،وهى تلك الإحالات الرئيسية أو الثانوية التى التى الإدئ

(1) Halliday\& Ruqaiya Hasan : Cohesion in English , p.r r. \& Raphael Salkie: Text and discourse analysis, p. 70 .

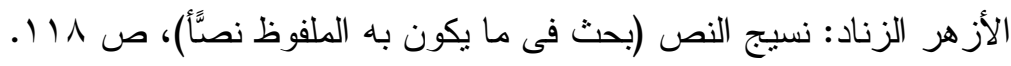

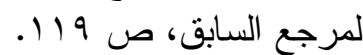

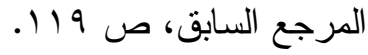

(0) Raphael Salkie: Text and discourse analysis, p.70.

$$
\begin{aligned}
& \text { (T) صبحى الفقى: علم اللغة النصى بين النظرية والنطبيق (دراسة تطبيقية على السور }
\end{aligned}
$$

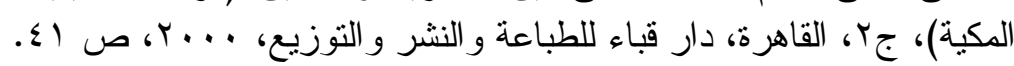




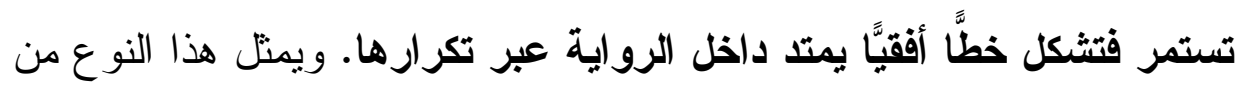

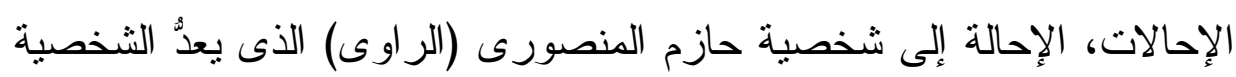

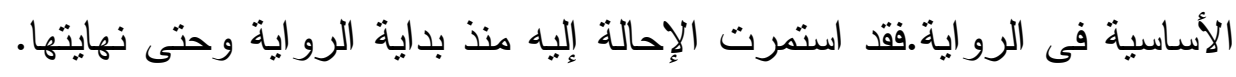
ويمنلها أيضًا عدة إحالات أخرى خطية داخل الرواية تتفاوت فى موقعها داخل

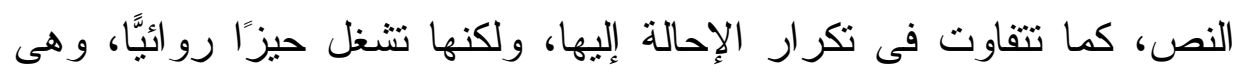

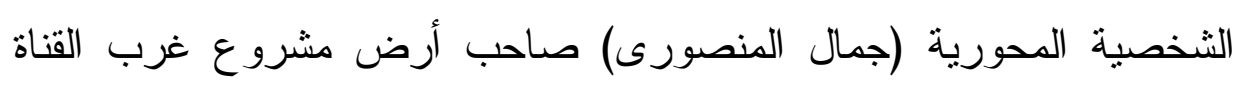

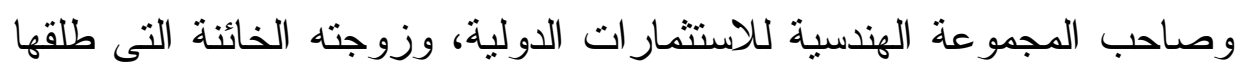

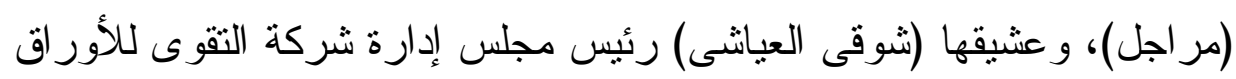

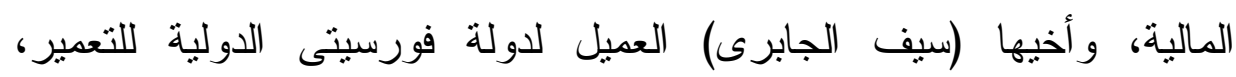

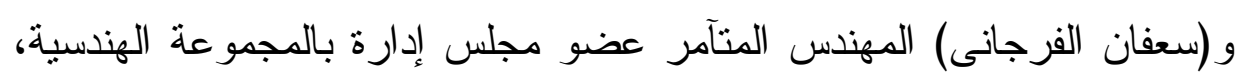

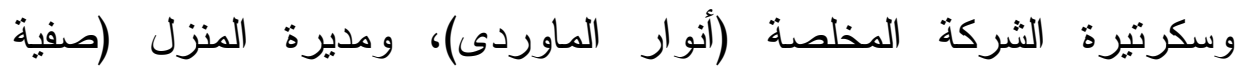
العايدى)، و (عماد) ابن حازم المنصورى، و (فيلا الفردوس، وفيلا الوسام، وفيلا الثهاب)منزل جمال المنصورى، ومقر المجموعة الهندسية للاستثمارات،

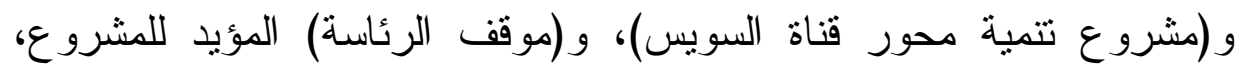

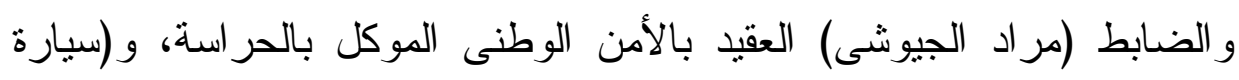
المر اقبة) السوداء.

أما الإحالات الرأسية (الإحالات الومضة) فهى تلكالتى تظهر مرة واحدة

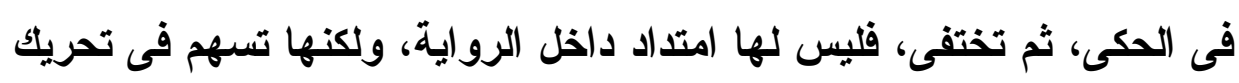

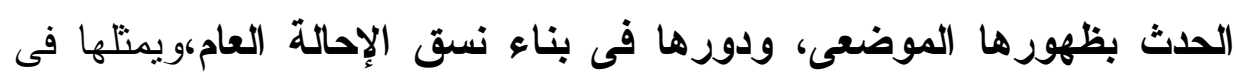

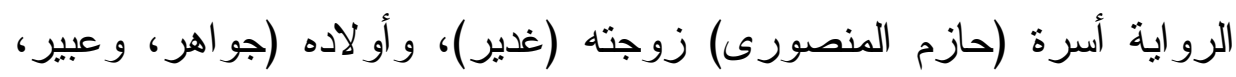

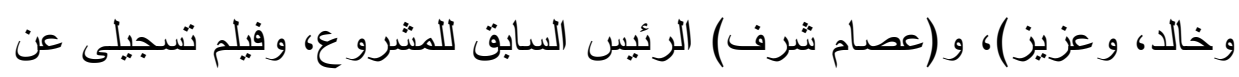

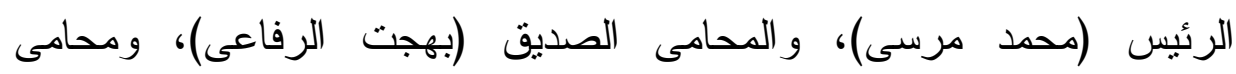
المجموعة الهندسية (صبحى الجمال)، و الصديق (عرفان الجيوشى)، و (أسماء 
د · مزة شبل محمد

قبلان) السورية زوجة (سيف الجابرى)، و السائق (عطوان)، و السائق (شعبان)، و (الخادمة مبروكة المنياوى)، و الحارس (و هدان السوهاجى)، وزوجته (عديلة)، و ابن عمه (عمران السوهاجى) و(عوف) البستانى، و المحامى (بهجت رفعت)، و الصديق الاكتور (مختار العادل) و (الحكومة)، و الصديق (حامد العايدى) تاجر السيارات بطنطا وزوجته، و(أثخاص المراقبة)، و (منفذو عمليات الاغتيال و التصفية)، وحديقة (جروبى)، و (مدة الزواج بين جمال المنصورى وزوجته مر اجل) التى استمرت (ثلاثثن عامًا)، و(الثوار)، و (قصر الاتحادية)، و (قصر

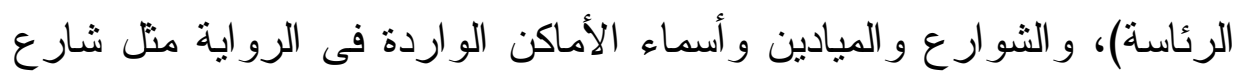

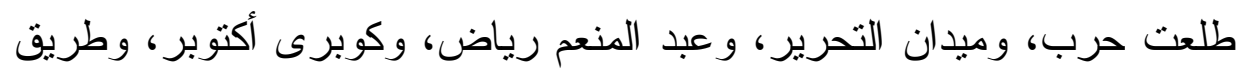
النصر، و التجمع الخامس، وعباس العقاد، ومشرحة زينهم، ومقابر القطامية، ودار العزاء بمسجد عمر بن عبد العزيز . الإحالات المتصلة والإحالات المنفصلة فى النص السردى: تحتوى الرو اية على عدة إحالات للمر اجع المستخدمة،من حيث اتصالها، أو انفصالها، حيث يشكل البعض منها محورًا منصلاً، فنتو الى الإشارة إليها،

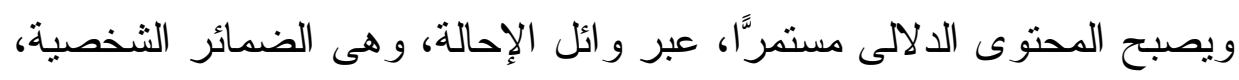
وأدوات الإثارة، و الأسماء الموصولة، كما نرى فى الإحالة على مرجع سكرنيرة الثركة (أنوار المواردى) فهى تدين بالفضل للمهندس (جمال المنصورى) فتقول:»له فضل" علىَّ لا أنساه. علمنى ودربنى ومنحنى وأسرتى الاستقرار دون مقابل، وألحقىى بسكرنارية المجموعة الهندسية، لأكون عينه التى تزى، و أذنه التى تسمع."' (') فتتشكل الإحالة على ذلك المرجع باستخدام ضمائر المتكلم مع الأفعال (أنساه، علمنى، دربنى، منحنى، ألحقنى، أكون)، ومع الاسم (أسرتى)، ومع 
حرف الجر (علىَ)). وتبعًا للاور الذى اختاره الكاتب لذللك (المرجع) بوصفه

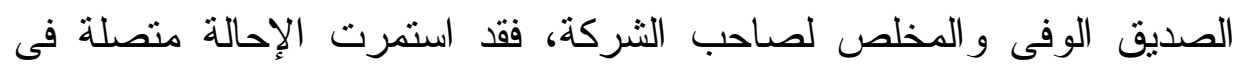

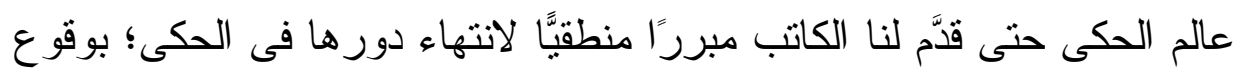
حادثة اغتبالها.

وتتنتمل الرواية أيضًا على نوع آخر من الإحالات، يمكن أن نطلق عليه

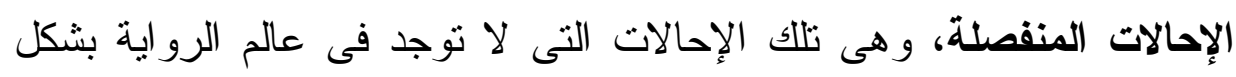

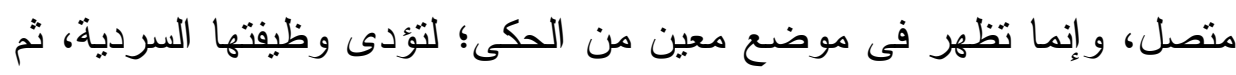

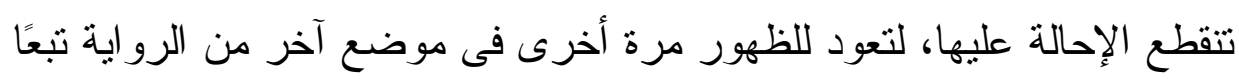

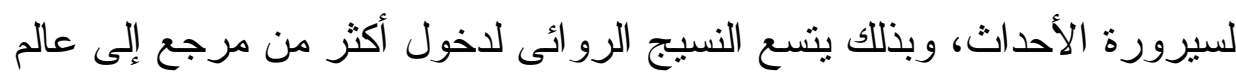
الحكى تبعًا لسيرورة الأحداث.

ومن ذللك النوع الإحالة على مرجع (مراد الجئل الجيوشى) الضابط بالأمن

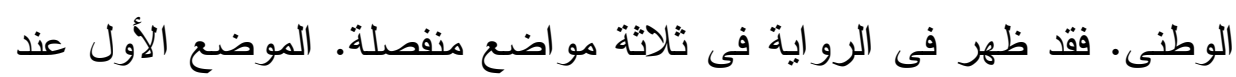

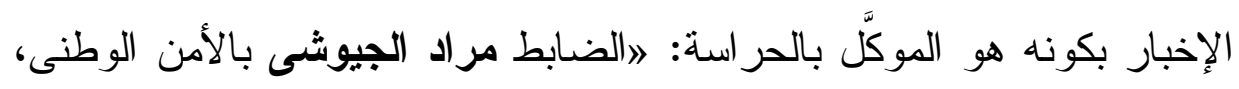

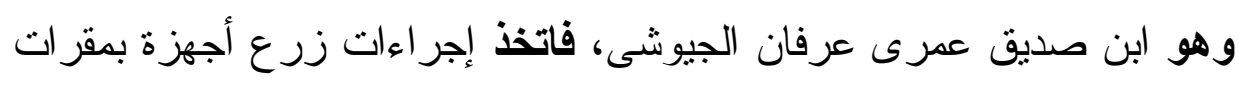

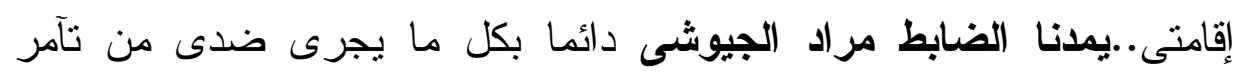

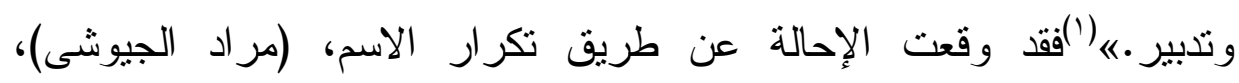

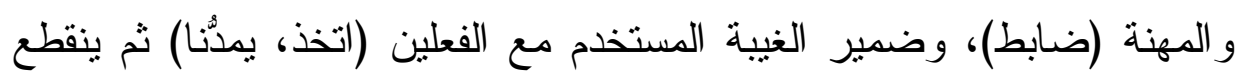
ظهوره فى الحكى، ليعود للظهور مرة أخرى فى موضع ثانٍ عند مقتل (جمال

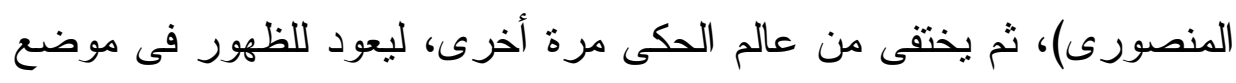

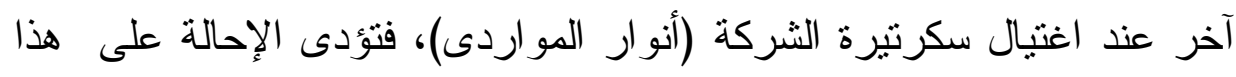

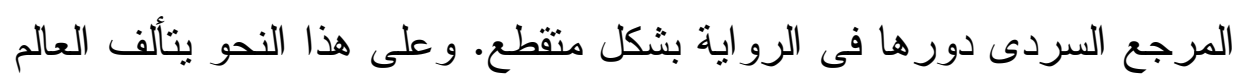

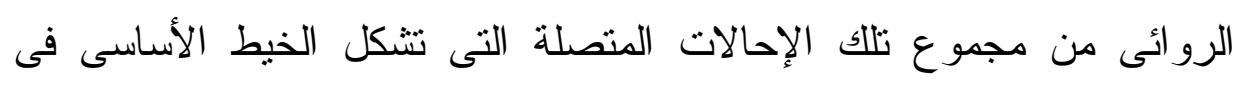




\section{د. ـ عزة شبل محمد سـ}

الحكى، و الإحالات المنفصلة التى تتشابك خيوطها مع الإحالات المتصلة؛ لتؤدى وظائف حكائية معينة داخل السرد.

\section{الإحالة التكر اريةة:}

ونقصد بها تلك الإحالة التى يتكرر فيها بؤرة الإحالة، ويتعدد الإطار الإحالى لها مع كل إير اد جديد فى النص. ويؤدى ذللك النمط من الإحالة التى أطلقناها عليها (الإحالة التكرارية) وظيفة مهمة من وظائف التو اصل بين المبدع و المتلقى. فعلى مستوى إنتاج النص، يسمح هذا النوع من الإحالات بإدخال المعلومات الجديدة التى يريد المبدع بناء عالمه الروائى بها. فمع كل تكرار يدخل الكاتب صفات جديدة للمرجع/ المراجع المستخدمة،سواء بالوصف الفيزيقى، أو الفكرى، أو الاجتماعى، أو الثعورى، تبنى تلك المعلومات فى مجموعها التصور الذهنى الذى يريد الكاتب إيصاله إلى المتلقى. ويمكن التمثيل لدور الإحالة التكر ارية فى بناء الثخصية بتكرار الإحالة على مرجع (أنوار المواردى) بضمائر الغيبة. فمع كل تكرار يقدم الكاتب صفات جديدة للمرجع من خلال الإطار الإحالى لها، يرسم الثكل الخارجى للشخصية،اتأملتها قبل أن تجلس. تماثلنى فى الطول رشيقة القو ام. تابعها وهى الإه تستقر فى مقعدها: بيضاوية الوجه. بيضاء بعينين خضر اوين باسمتين. ذات أنف دقيق يتوسط وجهها البيضاوى، ويعلو شفتين قرمزيتين، بينما انسدل

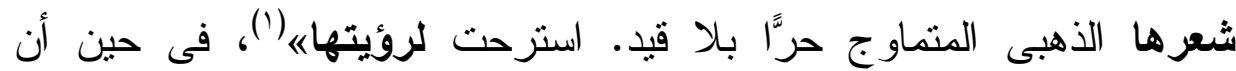
الإحالة التكر ارية علىمرجع (حازم المنصورى) باستخدام ضمائر المتكلم قد قامت بوظيفة سردية أخرى، وهى إظهار موقفه الشعورى تجاه (أنوار

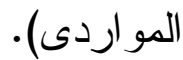


ومن ناحية أخرى،فعلى مستوى التلقى، فإن نكر ار الإحالة يُحدِث ألفة بين

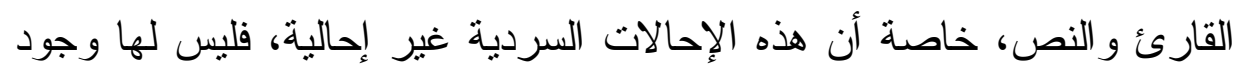

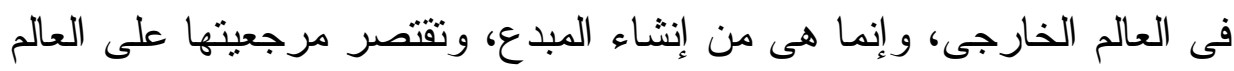

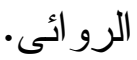

وتتعدد وظائف الإحالات التكرارية فى الرواية؛ لتنىى فكرتها الأساسية،

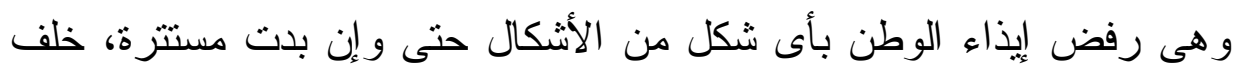

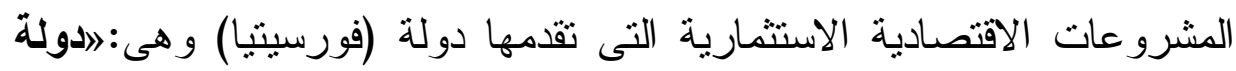
صغيرة. لكنها تريد أن تكوندولة عظمى بما تنفقه من أموال باهظة ليسهل

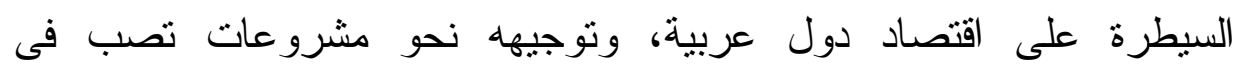

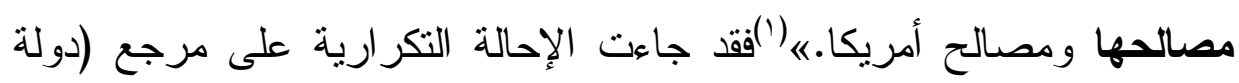

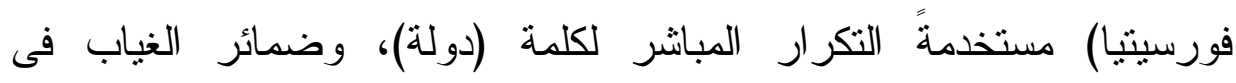
الكلمات: (تريد، تكون، تتفقه، مصالحها).

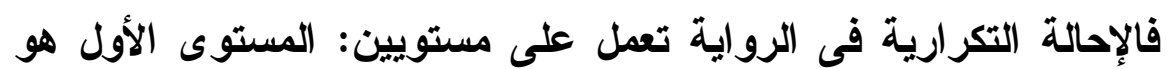

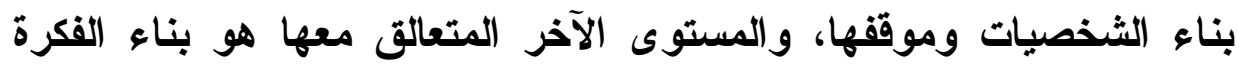

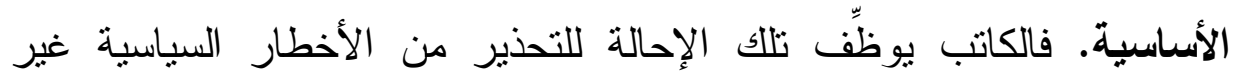
المباثرة التى تتعرض لها البلاد من خال هذا الرمز السردى المتمثل فى تتفيذ

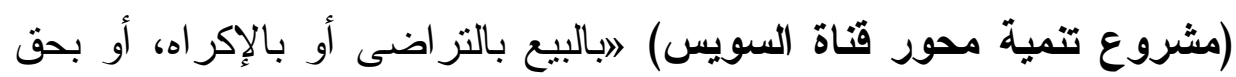

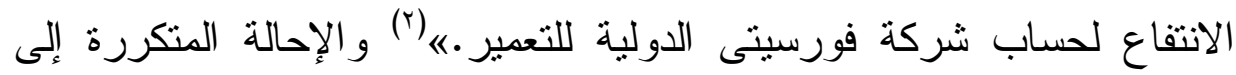
خطورة المشروع، ومن يققون وراء تتفيذه، وموقف المخلصين الر افضين له، لهابه

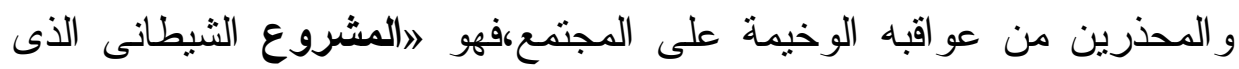




\section{د. د عزة شبل محمد بـ}

سيكوِّن دولة داخل دولة.ه(')فيأتى تكر ار الإحالة على مرجع (المشروع) مؤكدًا

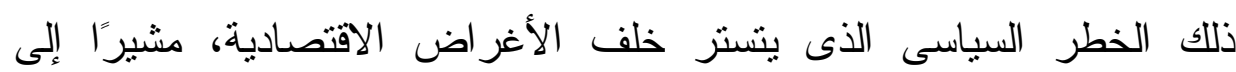
الخطورة الأكبر عبر تكرار موافقة الرئاسة وتأييدها ومخالفة آر اء المخلصين من أبناء الوطن،ا(فلن يحاسبهم أحد فى عهد يساند مشروع محور القناة. ورالا تخفى الرئاسة رغبتها فى تتفيذه فى أقرب وقت، مخالفة برغبتها آراء خبر اء الوطن المخلصين ونخبته الاقتصادية الحريصة على ثروات الوطن

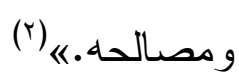

و هنا تبرز الإحالة التكرارية موقف الثخصبات من هذا المشروع بين مؤيد ومعارض. فالمشروع مؤيد من الرئاسة، و الحكومة، ومؤيد أيضًا من (سعفان

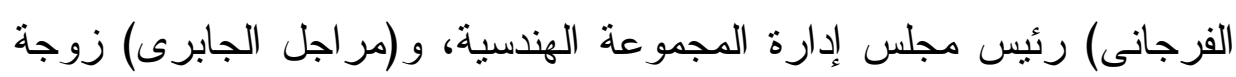
(جمال المنصورى)، فالمشروع ا(تضمنه الرئاسة، وتوافق عليه الحكومة، بل إنها وافقت بالفعل.ش(־) و (سعفان) ايؤكد على ضرورة العمل السريع لإقرار مشروع محور قناة السويس..فسار عت مر اجل قائلة: أنا أويد المشروع، وأوافق بإن

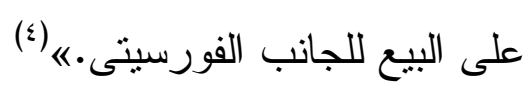
فتكرار الضمائر الشخصية (الغيبة والمتكلم) يؤكد الأصوات المؤيدة للمشروع، فى حين نجد الإحالات المتكررة على مرجع (جمال المنصورى)،

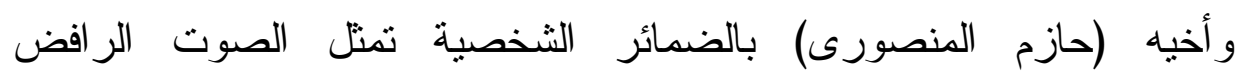
للمشروع، بقوله:اأرفض المشروع برمته، كما رفضه شقيقى جمال. أرفض

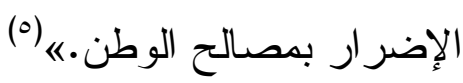

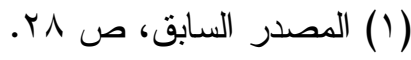

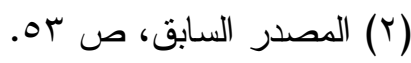

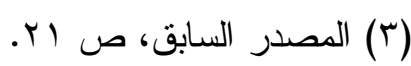

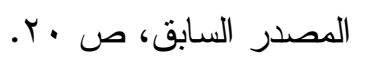

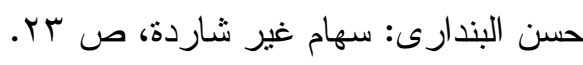




\section{عنقودية الإحالة ودورها فى بناء السرد والحوار:}

يتميز النوع الروائى أيضًا بوجود ما يمكن أن نطلق عليه (عناقيد الإحالة)؛

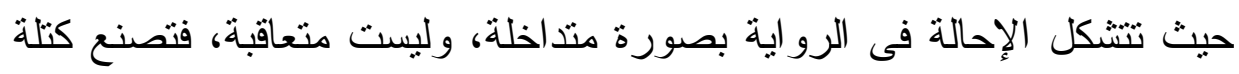

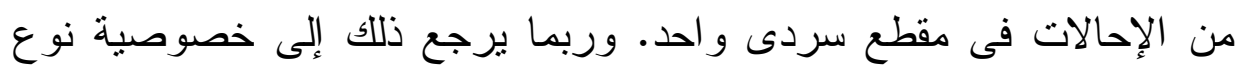

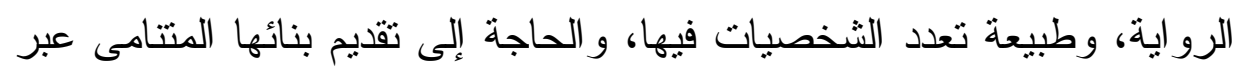

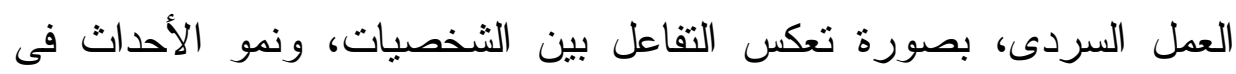
فضاء مكانى وزمانى ما.

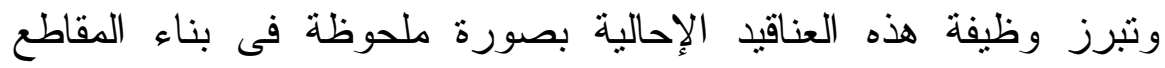

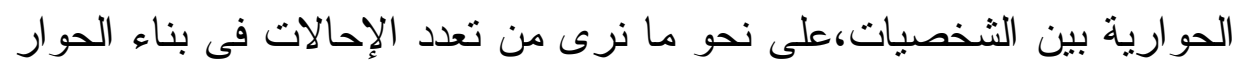

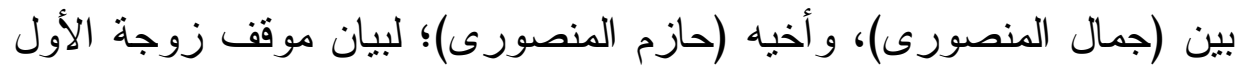

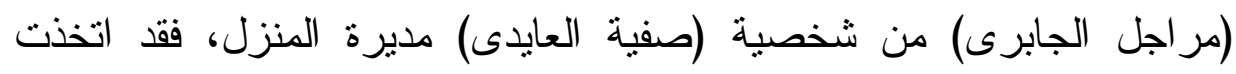

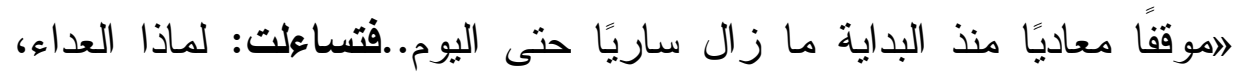

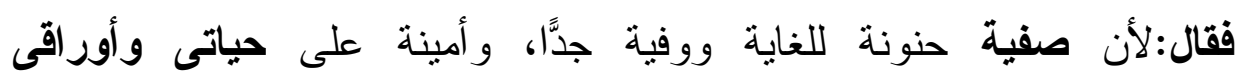
وأموالى.《) (1)

فقد اعتمد بناء الحوار هنا على وجود أربعة مراجع، والإحالة عليها

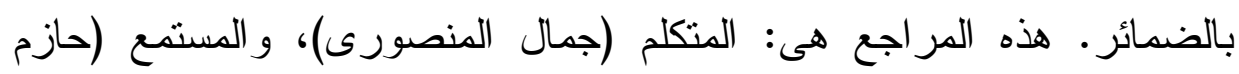

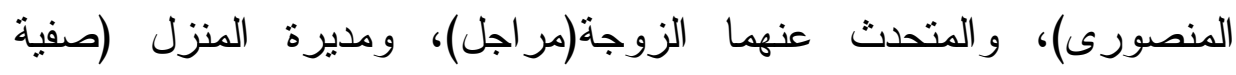
العايدى).

و لا تقتصر وظيفة العناقيد الإحالية على بناء الحوار فى الرواية، بل تسهم أيضًا فى تثكيل المقاطع السردية بها، على نحو ما نجد فى ذلك المقطع القائم

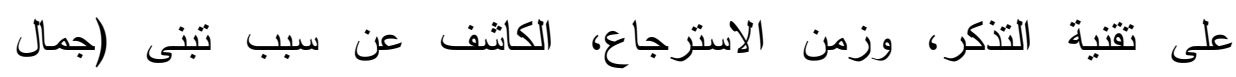

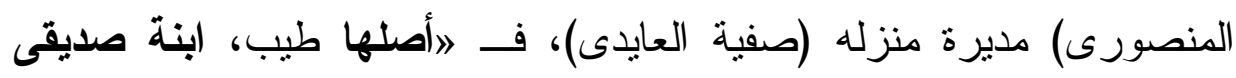




\section{د.}

الأى لقى هو وزوجته مصرعهما فى حادث طائرة أسوان المشئومة.. تعهرتها بالرعاية والتعليم منذ أن كاتت فى العاثرة، وتابعتُها حتى حصلت على مئى

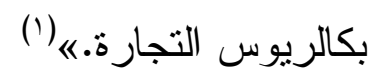

حيث يثكل هذا المقطع السردى عنقودًا من الإحالات يضم المراجع: صاحب العمل (جمال المنصورى)، ومديرة منزله (صفية العايدى)، وو الدها، وو الدتها. وتتضافر ضمائر المتكلم مع ضمائر الغيبة المتصلة بالكلمات: (أصلها، صديقى، تعهدتُها، كانت، تابعتُها، حصلت) فى نشكيل ذلك المقطع السردى. (المر

\section{تعدد أدوار المرجع، والروابط الإحالية بينها:}

تتعدد أدوار المر اجع فى الخطاب الروائى تبعًا لتعدد الروابط الإحالية بين الشخصيات بما يصنع شبكة الإحالات فى النص، فلا تصبح الإحالات داخل النص إحالات منفردة متفرقة ومفككة، و إنما تصبح نسيجًا متداخلاً. فإذا أخذنا مثالاً لمرجع شخصية المهند (جمال المنصورى)، فسنجد أن هذا المرجع مأن تتعدد أدو اره داخل الرواية، فهو أخ للمرجع (حازم المنصور)، وزوج للمرجع (مر اجل الجابرى)، وصديق للمرجع (الدكتور مختار العادل)، وصديق المحامى(بهجت الرفاعى)، ومدير العمل للمراجع (أنوار المواردى) مديرة المكتب، و المهندس (سعفان الفرجانى) وصاحب المنزل للمراجع (صفية العايدى) مديرة المنزل، و (وهدان السوهاجى) حارس الفيلا، و (مبروكة

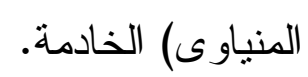

فهنا تتعدد الأدوار للمرجع الواحد تبعًا لعلاقته بالمراجع الأخرى مع سيرورة الحكى فى الرواية، بما يصنع شبكة منداخلة من العلاقات الإحالية، فيشكل بنية السرد التفاعلية. 


\section{المبحث الثالث}

\section{الإحالة وتثكيل الخطاب السرد سياسى}

العنوان والغلاف والإحالة السيميولوجية :

إن العنوان هو 》العتبة الأولى للنص، وتتجلى امتداداته و إثثار اته من خلال

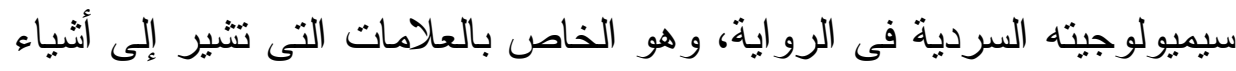
أخرى، حيث يحيل إلى أثنياء قد يقصدها الروائى أو بستشفها الناقد فى أثناء

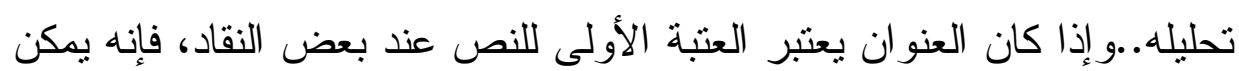

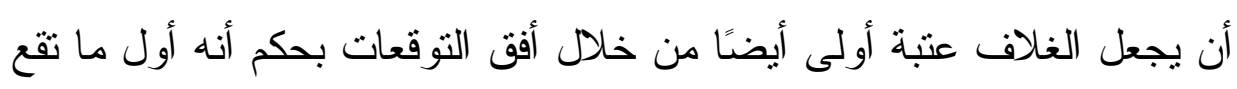
العين عليه.ی) (1) لقد اختار الكاتب(سهام غير شاردة) عنوانًا لروايته التى تميزت بتضفير الخطاب السياسى مع الخطاب السردى، للتعبير عن أيديولوجيته.فجاء استخدام

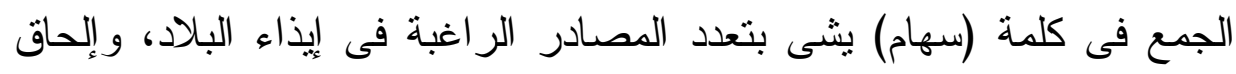

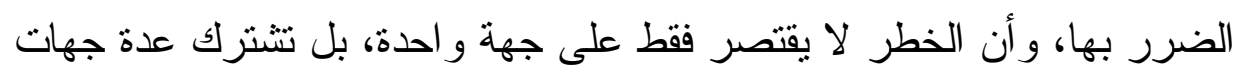

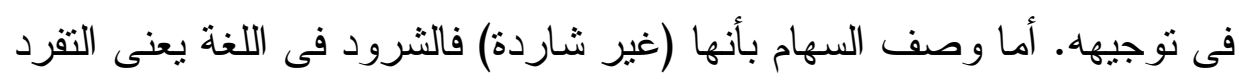

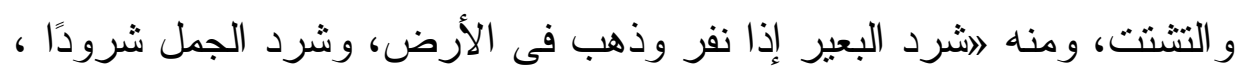

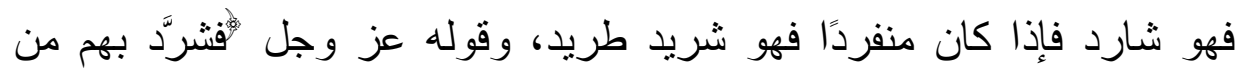

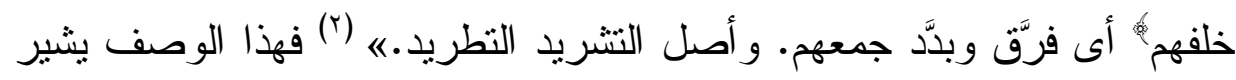

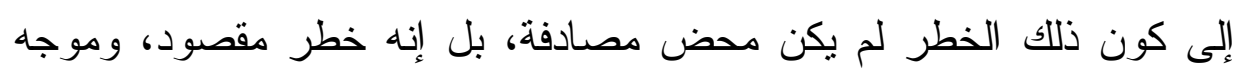

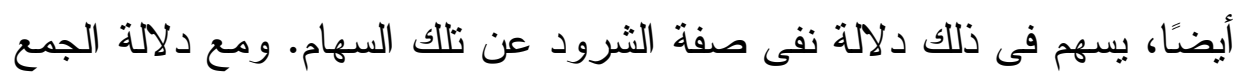

(1) عزوز على إسماعيل: عثبات النص فى الرواية العربية- دراسة سيميولوجية سردية،

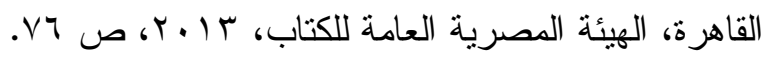
(Y) ابن منظور : لسان العرب، القاهرة، دار المعارف، د.ت، لـان، مادة (شرد). 


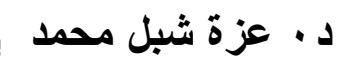

ودلالة نفى صفة الثرود، تتبئ دلالة العنوان بوجود خطر جمعى مقصود متفق عليه من جهات متعددة مع وجود نية وقصد الإيذاء.

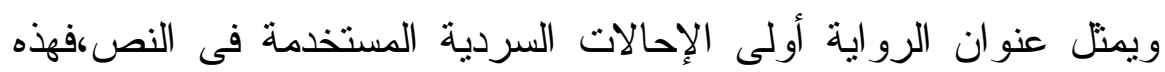

السهام المقصودة و المتعددة المصادر وتعرف وجهتها، ولكنها فى الوقت ذاته

مجهولة وغير محددة تمامًا، وهو عبَّر عنه دلالة تتكير كلمة (سهام).

و إذا كان العنوان ا(من جهة المرسل؛ هو نتاج تفاعلى علاماتى بين المرسل

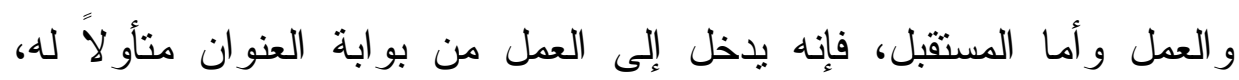

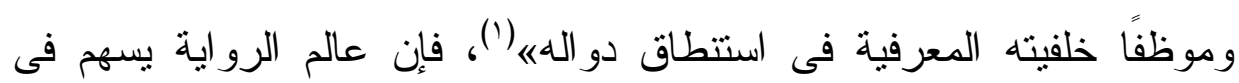
تأويل سيميائية العنوان، من خلال تكرار الإحالة على الكلمة الرئيسة فى لئ العنوان وهى (السهام)، و التز ادف فى الوصف بين كلمة (مقصودة ومحددة)،

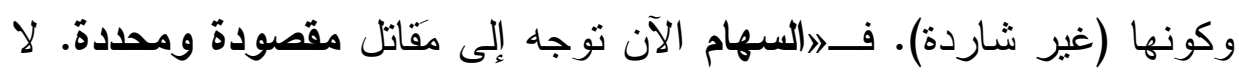
يصدق عاقل أن هذه الطلقة أو تلك أو هذا الحجر أو ذالك لم يقصد بها شخصيات معلومة ومجهولة، لأنها طلقات و أحجار شاردة. لا يمكن معرفة من

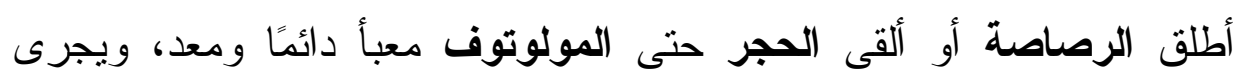
استعماله بأوامر من تتظيم غير مرئى فى الوقت المناسب.ی)(r) إن تعددية الأسلحة، الطلقات، و المولونوف، والأحجار التى ربما تزمز إلى قضية أطفال الحجارة وفلسطين،تؤكد كون هذه السهام غير شاردة، ويقصد بها التآمر على ولى الوطن العربى برمته، وليس على مصر وحدها، فى الوقت المناسب، من تتظيم وصفه الكاتب بأنه غير مرئى. فهم لايوجهون لوطنى أعتى الضربات ويصوبون ولئ وهن

(1) محمد فكرى الجزار: العنوان وسميوطيقا الاتصال الأدبى، القاهرة، الهيئة المصرية العامة للكتاب، 1991 1، ص 19 ـ 
على صدور أبنائه أمضى السهام..تتطلق السهام بأيد مدربة خبيرة تهدف إلى الى

تحقيق ما سبق." (')

وقد ساعدت سيميائية الغلاف فى الكثف عن تلك الدلالة. فقد كانت هنآك

صورة لثلاث كائنات هلامية غير محددة الهوية ذات سهام حادة وعيون

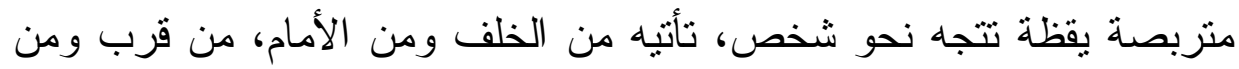

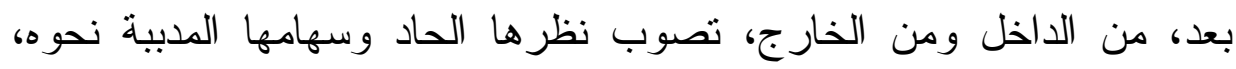
إحداها خرج من خريطة الوطن العربى بالقرب من البحر الأحمر، وقد كانت

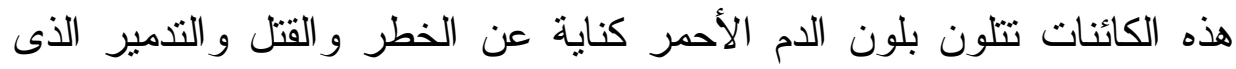

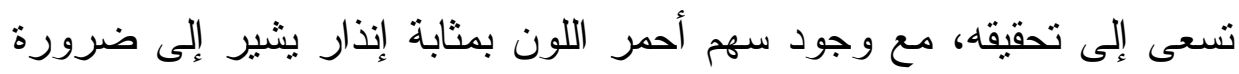
الانتباه إلى هذا الخطر الجديد البادئ فى الظهور • وقد عبرت الصورة عن تلكي

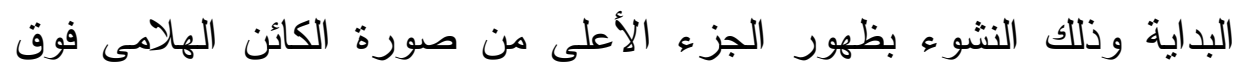

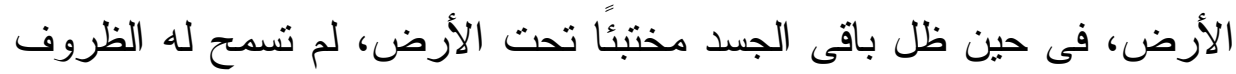

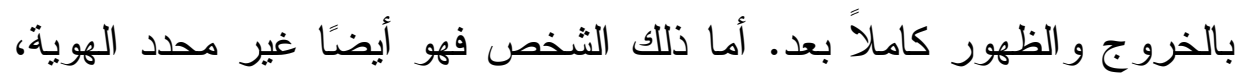

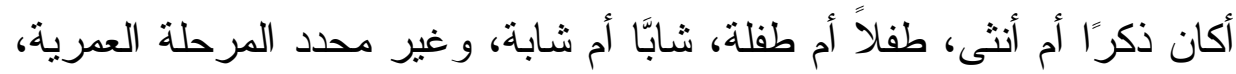

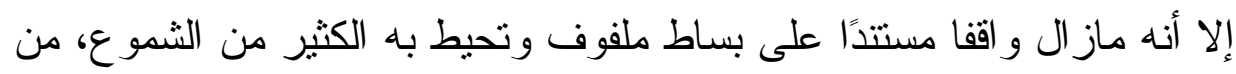
الأمام ومن الخلف، بعضها قريب، و البعض الآخر بعيد. الثموع القريبة قليلة

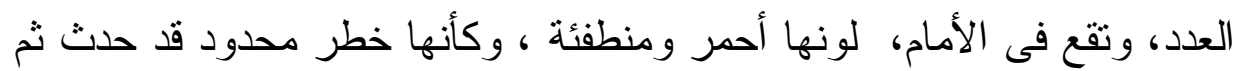

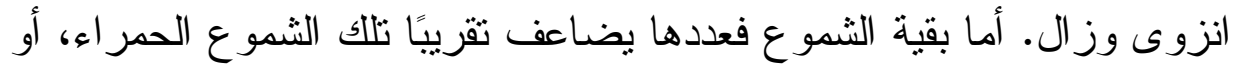

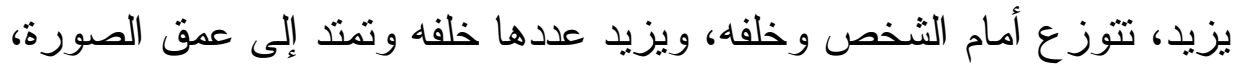

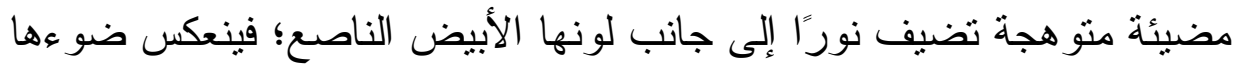

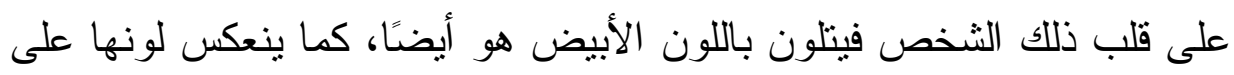

(1) المصدر السابق، ص ص بץ (1، ؟9. ونلاحظ تكرار الإحالة داخل الرواية على كلمة

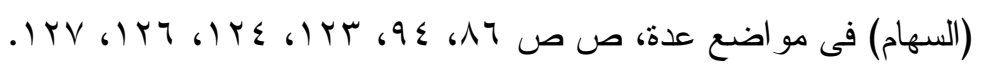




\section{دـ · عزة شبل محمد}

خريطة مصر • إن دلالة الإضاءة وكثرة الثموع، وتوزعها فى الصورة بين الأمام و الخلف، وزيادة عددها فى الخلف عنه فى الأمام، إنما يدل على الأمل ونل ولى الذى سينير المستقبل، و المنعكس على ذلك الثخص غير محدد الملامح الذى يرمز إلى الوطن العربى كله.

\section{الإحالات السردية فى عالم الرواية(الإحالات الاخلية):}

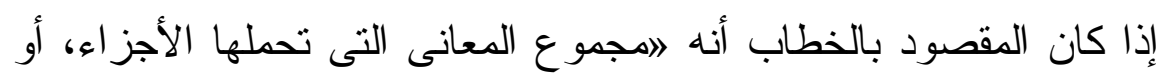
مجموع المقاصد الكلية المر اد إبلاغها.. الظاهرة والخفية: المعانى الأول

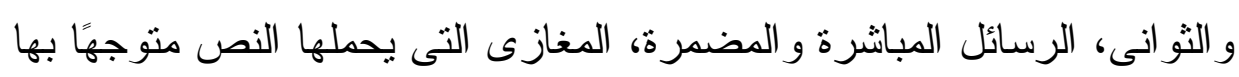
إلى متهيى لفهمها..فالخطاب تبعًا لهذا لا يتوقف عند حدود البنية النصية التى

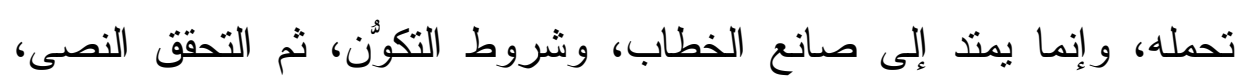

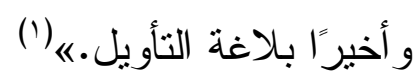

انطلاقًا من ذلك المفهوم للخطاب، فقد اثتنملت الرواية على عدة إحالات سردية ساهمت فى تعالق الخطاب السياسى بالخطاب السردى، والتعبير عن مقاصد مبدع النص، يمكن تصنيفها إلى: الإحالة الشخصية، و الإحالة المكانية، و الإحالة الزمانية، و الإحالة اللونية، و الإحالة المضادة، و الإحالة الرمزية.

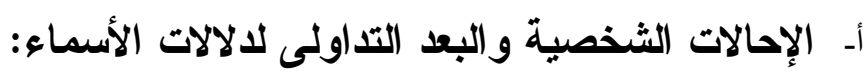
دائما ما يؤكد المبدعون أن اختيار هم أسماء الثخصيات فى العمل الأدبى

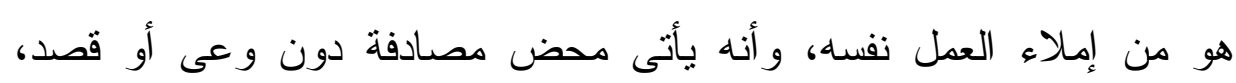
فينتهى دور المبدع بعملية الاختيار غير المتعددة - فى أحيان كثيرة- ليبدأ دور

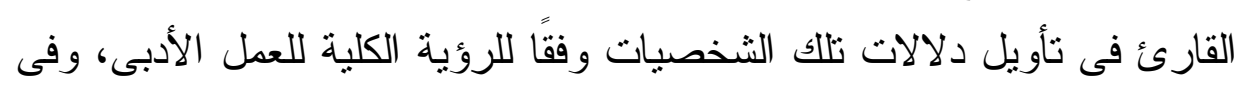
ضو ء معرفته بالمؤشر ات السياقية الممكنة.

(1) محمد بازى: صناعة الخطاب، الأنساق العميقة للتأويلية العربية، عمان، دار كنوز

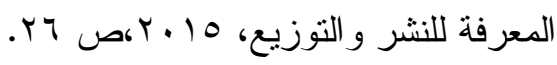


"او الو اقع أن الاسم العلم، يمثل اهتمام مخصوص لأى التداوليين الذين رأوا

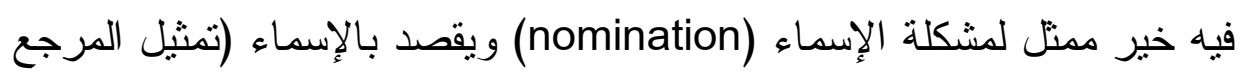
بو اسطة العلامة)..وهكذا، فإنه يكفى أن يحدد المتكلم و المخاطب الثنى الإه نفسه

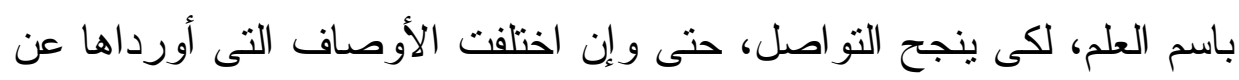

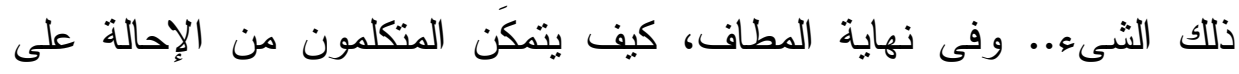

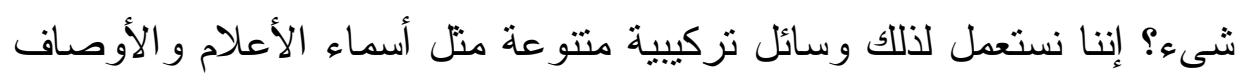
المخصصة و أسماء الإنشارة.《) (1)

لقد قدمت الرواية عدة أسماء مثلت الإحالات المعجمية داخل الرواية، يمكن

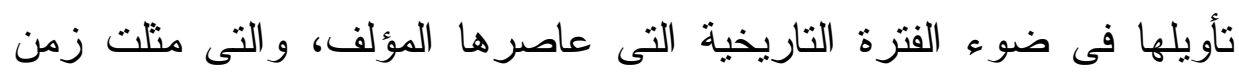

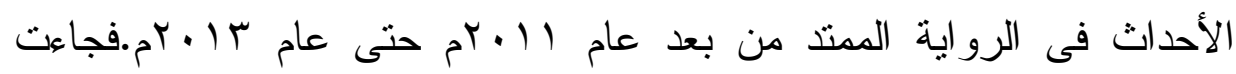

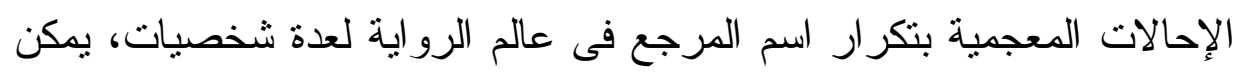

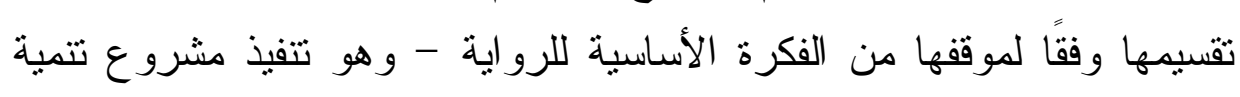
محور قناة السويس- إلى ثلاث مجموعات:

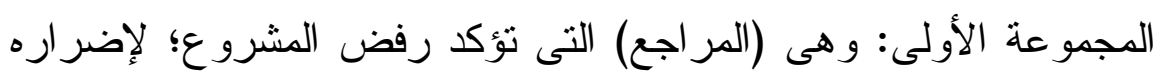

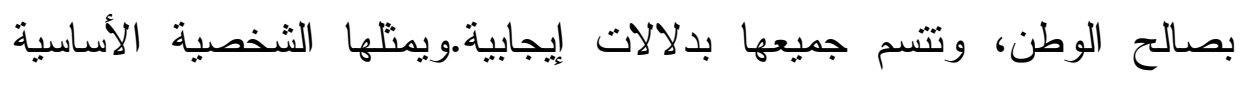

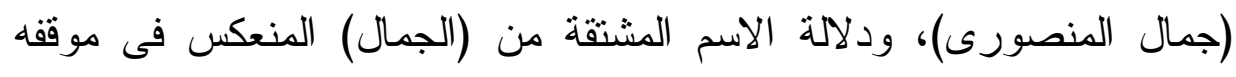

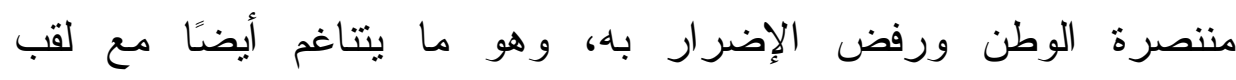

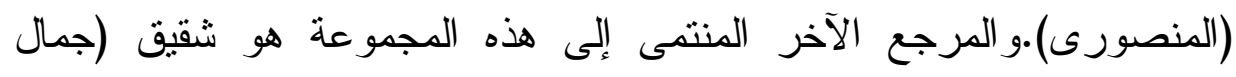

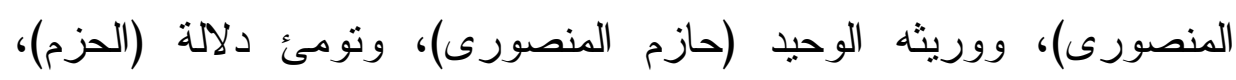

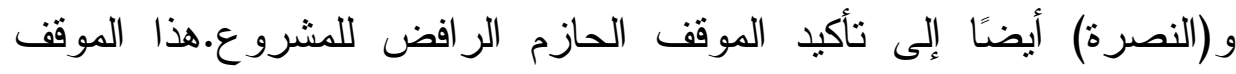

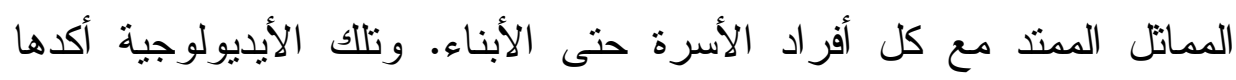

(1) صابر الحباشة: قضايا فى السيمياء والدلالة، عمان، دار كنوز المعرفة للنشر والتوزيع،

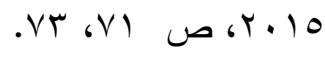


د.

الر اوى بالإحالة بضمير الجمع فى الكلمات (أبنائى، هم مثلى، لن يفرط أحد

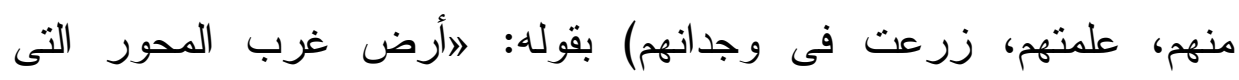
يصمدون على شرائها لتنفيذ المشروع بواسطة أيد غريبة ومريبة لا تعمل

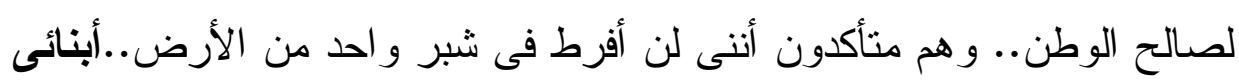
...سوف تؤول إليهم الثروة. وهم مثلى تمامًا لن يفرط أحد منهم فى شبر من

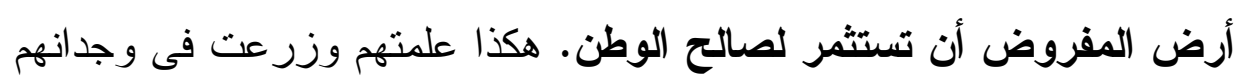
التمسك بهذه الأرض أو بأى أرض مصرية أو عربية.ی) (') ويتز ايد التأكيد على مصلحة الوطن، مع دلالات أسماء الثخصيات الثانوية التى تكتسب دلالتها من الدور الإيجابى الذى تؤديه فى التخييل السردى. فدلالة اسم رئيس مجلس إدارة الثركة الهندسية للتعمير (رمزى مجاهد) هى دلالة (الرمز) لكل (مجاهد) يسعى لإعمار الوطن، ويرفض منل تلك المشروعات الاقتصادية الوهمية التى تستهدف تخريب البلاد. ودلالة اسم سكرثنيرة (جمال المنصورى) (أنوار المواردى) على معنى(النور)، و الطريق (الوردى)، وهى دلالة تعكس دورها فى الحكى الذى ينير الطريق بإخلاص ومحبة لحازم المنصورى العائد من الخارج، ولا يعرف الكثير من الأمور. فهى تمنلك كل الأوراق و المستتدات التى تكثف المؤامرة

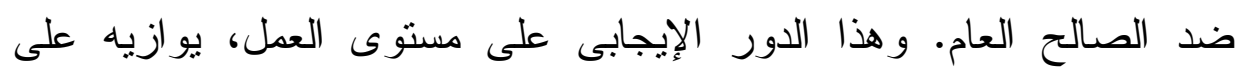
المحيط الأسرى دور المرجع (صفية العايدى) التى تتمتع بالصفاء و النقاء، وهى الإبى

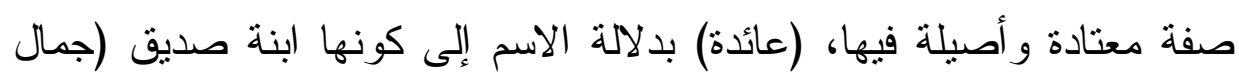

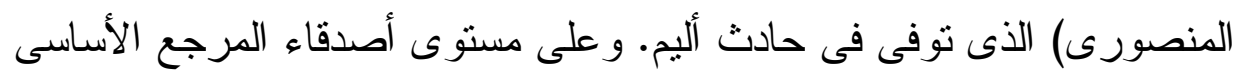

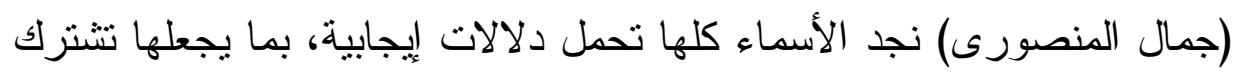
فى دلالة أساسية، وهى الإخلاص فى حب الوطن. فنجد الصديق الحميم(الدكتور 
مختار العادل)، ودلالة (الاختبار) مقصودة، ومقترنة بالعدل، والصديق المحامى لإله

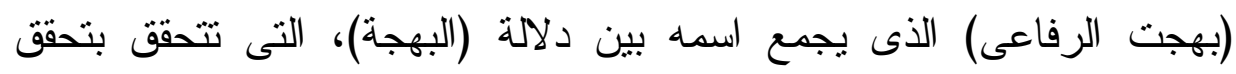

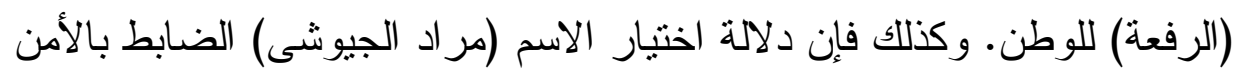

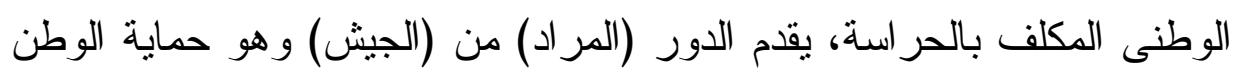

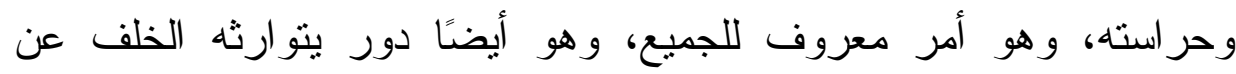

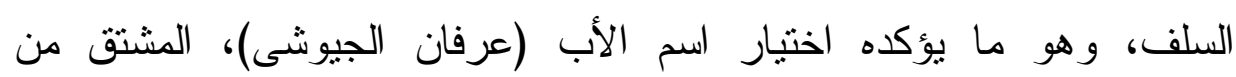

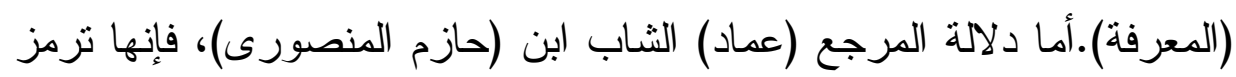

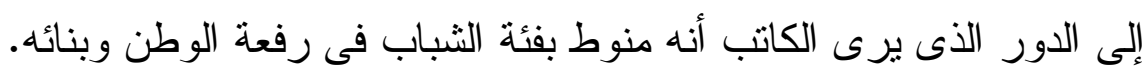

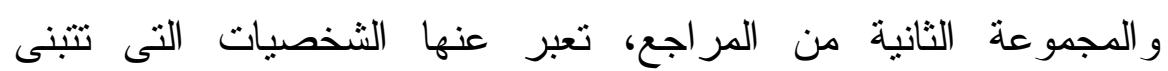

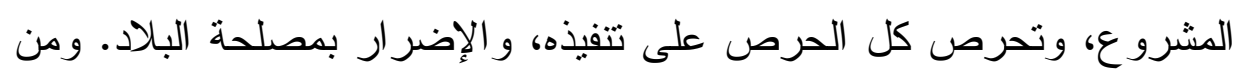

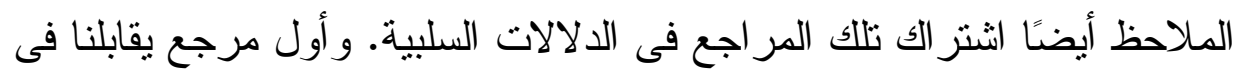
الرواية هو مرجع (مراجل الجابرى) زوجة (جمال المنصورى)، فنجد دلالة

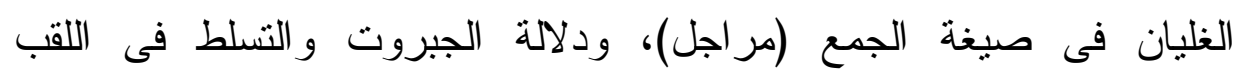
(الجابرى). ودلالة المرجع (سيف الجابرى) أخيها الذى يشترك معها فى اللقب الجب

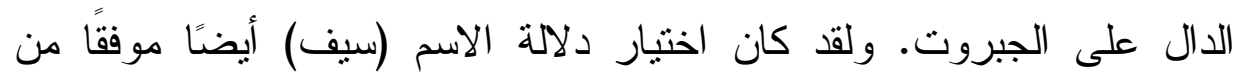

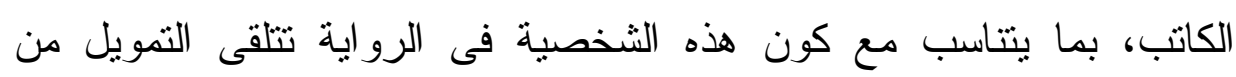

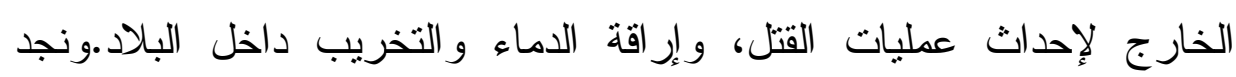

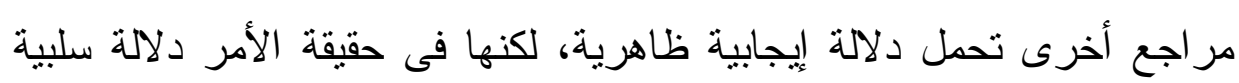

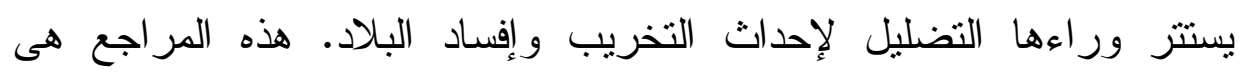
(صبحى الجمال) محامى شركة الاستثمار ات الدولية وهو جاهز دائمًا لمحاولة الفئل إفثال تحقيقات النيابة ومحاولة تضليل القضاء بشهود زوره، فهذه الثخدية

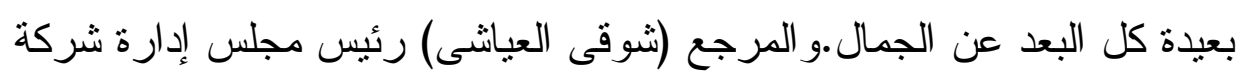

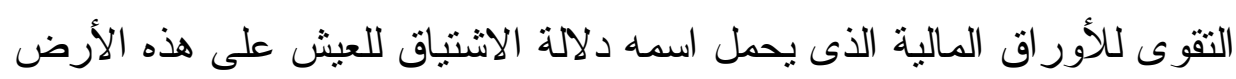




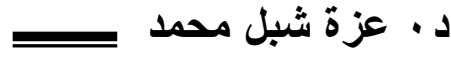

و التمتع بخير ها.و المهندس بالثركة (سعفان الفرجانى) الذى يبدو أنه يقدم حلو لاً اقتصادية لمشروعات سوف تسعف الحالة الاقتصادية للبلاد، وتحدث انفراجة،

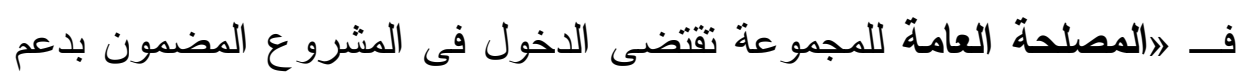

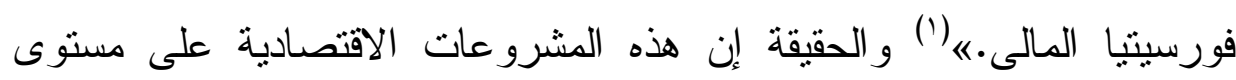

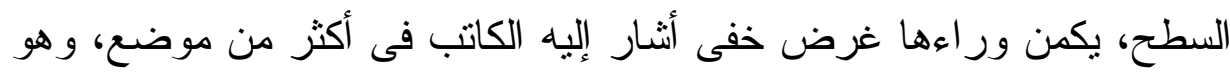
الاستعمار و الاستحو اذ وتخريب البلاد.

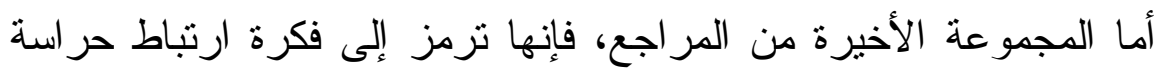

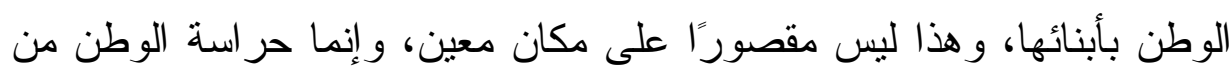

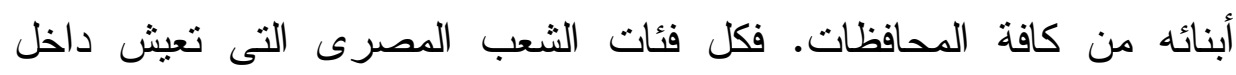
المجتمع المصرى منوط بها حماية الوطن، منل حارس الفيلا (وهدان

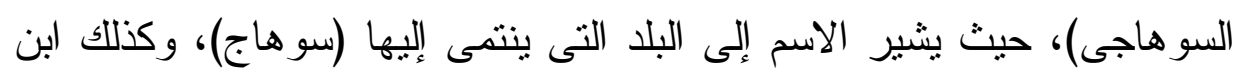

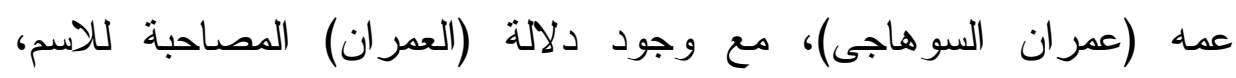
و الخادمة (مبروكة المنياوى)، حيث دلالة (البركة)، وكلها أيضًا صفات دهات إيجابية

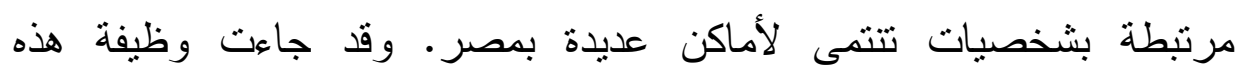

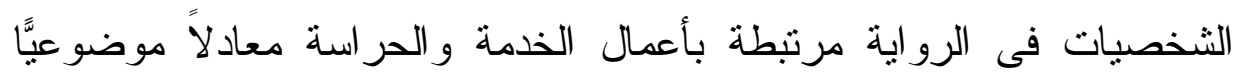
رزيَّا لحماية الوطن وحر استه.

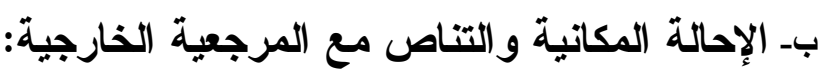
تمثل الإحالة المكانية على شركة (المجموعة الهندسية للاستثار ات الدولية)

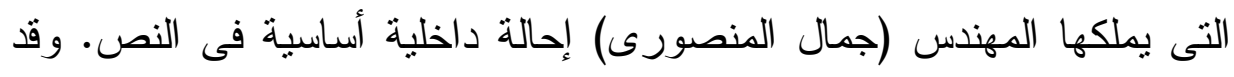

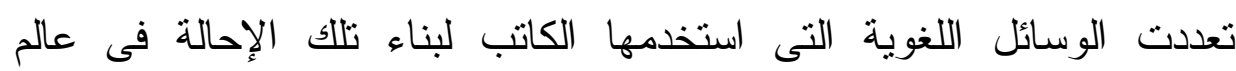

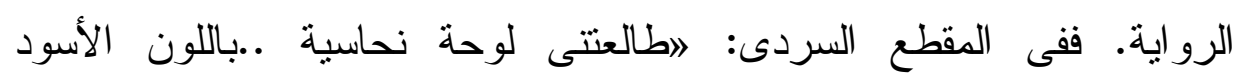

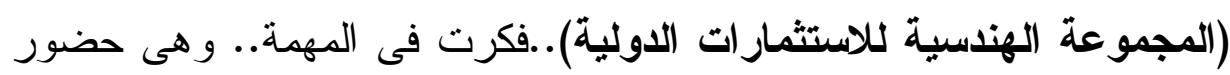


اجتماع المجموعة الاستثمارية نيابة عنه بوصفه أكبر مؤسسى المجموعة.ه(')

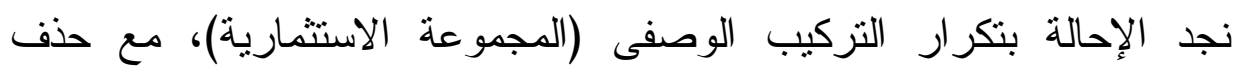

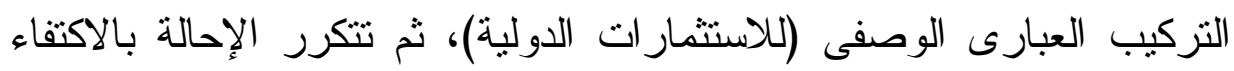

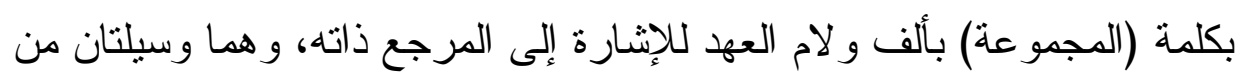

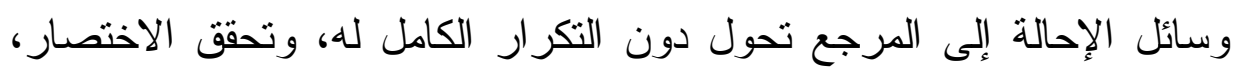

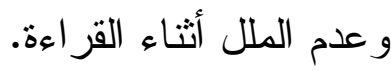
وتعد تلك الإحالة المكانية إحالة داخلية رئيسية تخضع للتخييل فى بناء

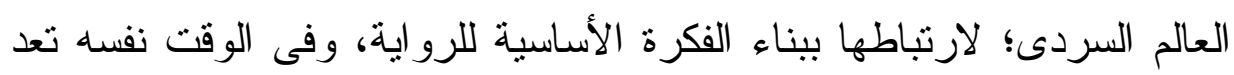

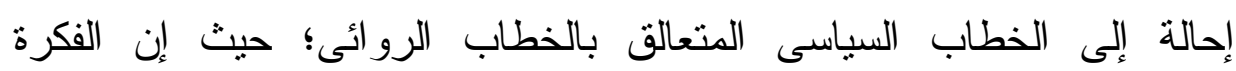

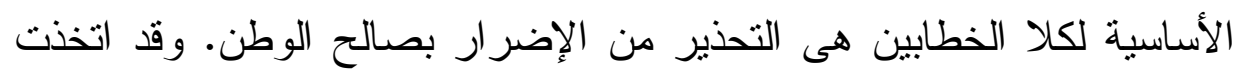

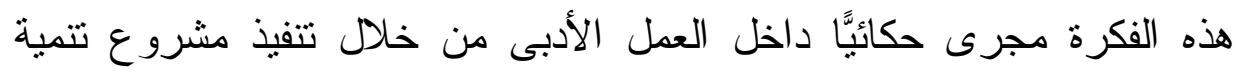
محور قناة السويس الذى لن ينت إلا من خلال هذه الثركة النى يملك فيها (جمال

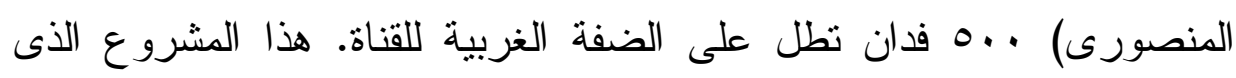
تتحمس له وترعاه شركة (فورسيتى الدولية للتعمير)، وقد أفادت الإحالة بالضمائر مع الكلمات (لكنها، تريد، تكون، تنفقها، مصالحها)، واسم الإثارة

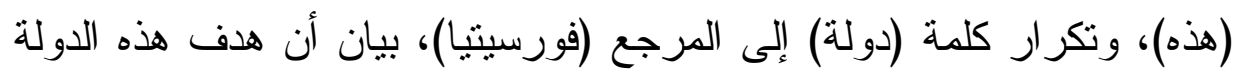

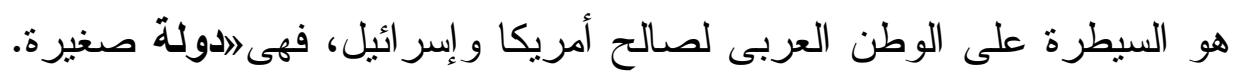

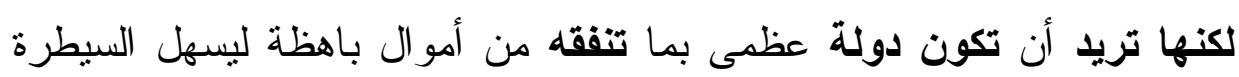

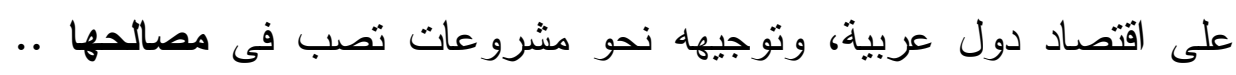

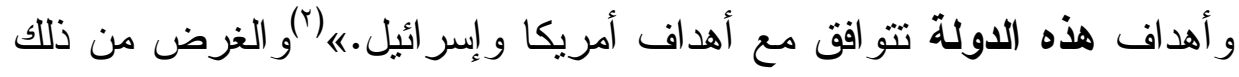

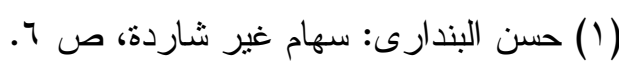

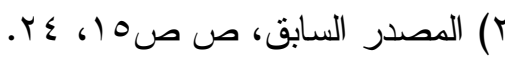

$$
\begin{aligned}
& -\wedge r \cdot-
\end{aligned}
$$




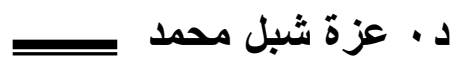

هو الالتواجد أو الحضور الدائم فى المثهد السياسى والاقتصسادى فى الدول العربية و الأسيوية و الإفريقية.ه (')

بينما تمنل الإحالات المكانية الأخرى الواردة فى الرواية إحالات داخلية، تتناص مع المرجعية الخارجية؛ نظرًا لكونها نشير إلى مرجعيات مكانية تحمل الأسماء ذاتها فى العالم الخارجى، فلها وجود مكانى حقيقى خارج العمل الأدبى، على نحو ما نرى من الإشارة إلى المشاريع الاستثارية الفى مناطق حيوية بمصر، منل غرب القناة وشرقها، والضبعة، ومرسى مطروح، ودمياط، وأماكن أخرى فى مصر..."(r) ويرتبط استخدام هذه الإحالات المكانية أيضًا ببناء إيديولوجية الكاتب بأخذ الحيطة و الحذر من وجود مشروعات استثمارية داخل البلاد من شركات أجنبية متعدية الجنسيات، تحت مظلة العولمة الاقتصادية. كما تشكل أيضًا الإحالات المكانية الداخلية المتتاصة مع المرجعيات الخارجية خيوطًا مشتركة تربط الخطاب الروائى بالخطاب السياسى. فقد نجح

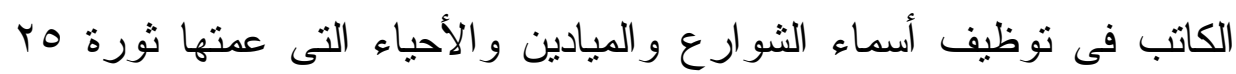
يناير، داخل البناء السردى التخييلى للرواية، فاستطاعت تلأك الإحالات المكانية الخارجية أن تستحضر فى ذهن المتلقى عملية الربط بين الأحداث التاريخية التى مرت بها البلاد فى تلك الفترة الزمنية، والأحداث الروائية داخل العمل الأدبى. خاصة أن الكاتب قد صرَّح بالحديث عن ثورة مب يناير على لسان إحدى الثخصيات بقوله: لاعماد دائم الحديث عن ثورة ه ب يناير التى تحمس

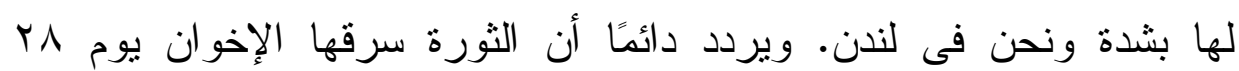
يناير.«(r) فتعددت أسماء الأماكن المحال عليها فى مقاطع كثيرة من الحكى،

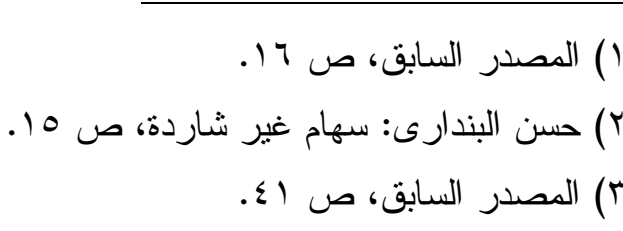


وتتاصت مع الأماكن التى احتشد فيها الثوار، وتعرضو اللإيذاء أو الاعنقال أو

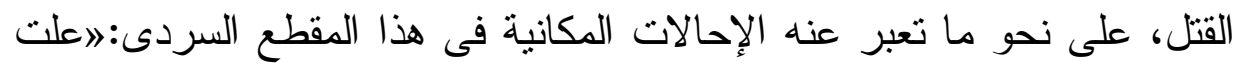

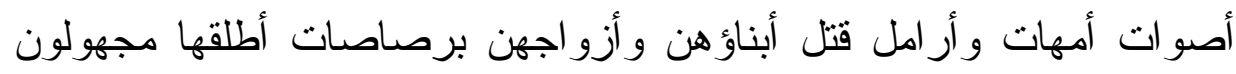

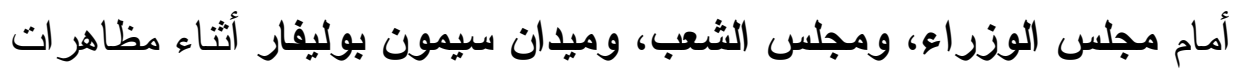

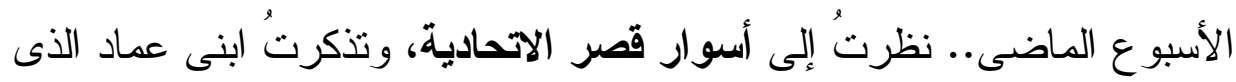

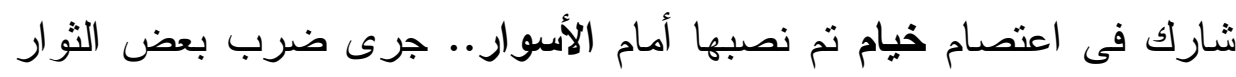

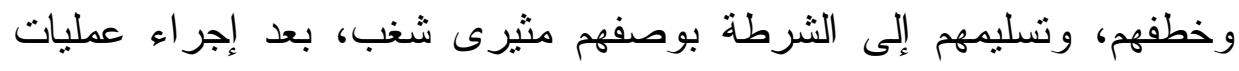

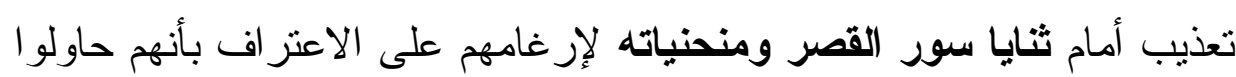

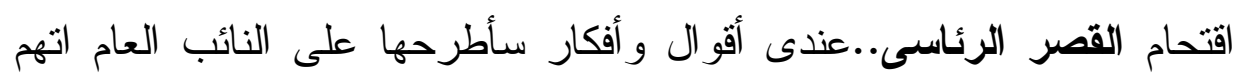

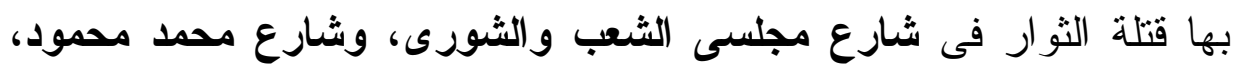

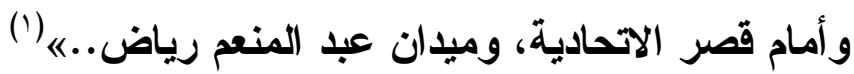

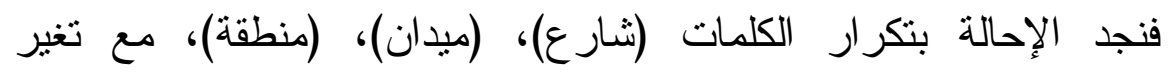

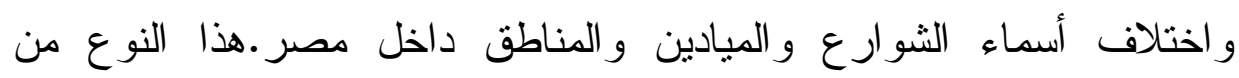

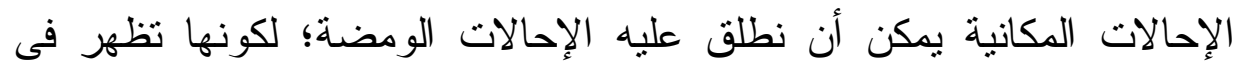

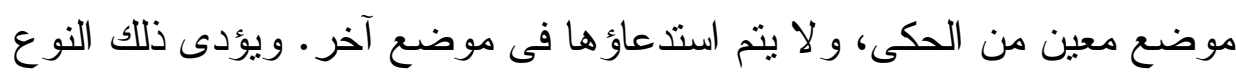

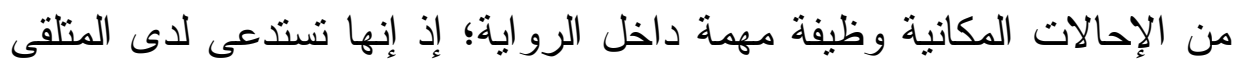

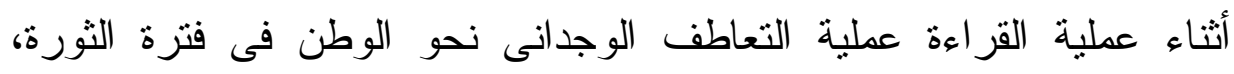

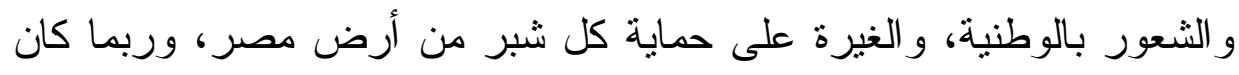

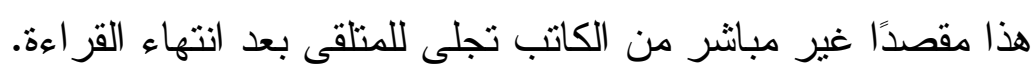

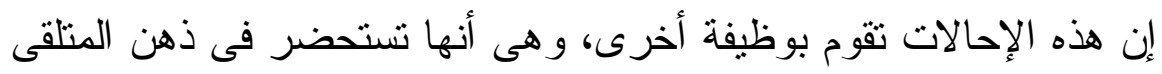

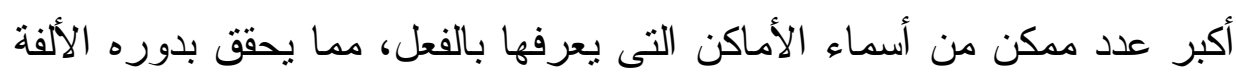

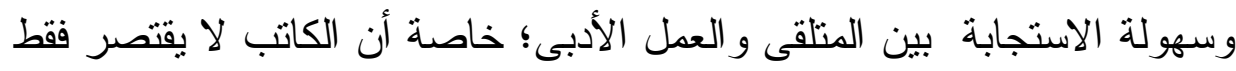




\section{د. د عزة شبل محمد بـ}

على استحضار عنصر (بؤرة الإحالة) من أسماء الأماكن، و إنما يستحضر معه العنصر الآخر المكون للإحالة، وهو (الإطار الإحالى) المتعارف عليه لدى الدى الهـ المتلقى، من منل الإشارة إلى المرجع (قاعة مسجد صلاح الدين بالمنيل) فهو (بؤرة الإحالة)، و إطار ها الإحالى أنها مكان للعزاء، أو بؤرة الإحالة (مقابر القطامية)، و إطارها الإحالى أنها للافن، أو بؤرة الإحالة (مشرحة زينهم) و إطار ها الإحالى لإجر اء عمليات النشريح. (') تـ الإحالة الزمانية: لقد لعبت الإحالات الزمنية دورًا بارزًا فى تعالق الخطاب السياسى بالخطاب السردى فى مو اضع عدة من الرواية. فكانت الإحالة إلى فترة زواج (جمال المنصورى) بزوجته (مر اجل الجابرى) التى استمرت ثلاثثن عامًا ثم انفصل عنها، معادلاً موضوعيَّا موازيَّا لفترة حكم الرئيس (حسنى مبارك) للبلاد، ثم تتحيه عن الحكم. وقد تأكدت هذه الدلالة من خلال تكرار تلك الإحالة فى الرواية مصاحبةً لموقف يبدو منتاقضًا. فنجد (جمال المنصورى) يوصى أخيه بزوجته التى تأكد من خيانتها له، مشيرًا إلى أنه لا يحب أن يخاصم أحدًا. ويبدو أن هذا الموقف الغريب و المتتاقض من الزوج تجاه زوجته الخائنة التى يوصى بالاهتمام بها فى العالم الروائى، يدعم أيضًا فكرة تأويله للإثنارة إلى هي الموقف الذى اتخذه (الرئيس مبارك) فى خطاب التتحى، وقد انفصل عن السلطة التى استمرت ثلاثين عامًا، مؤكدًا حبه لمصر • فنرى أن ما جاء على لسان

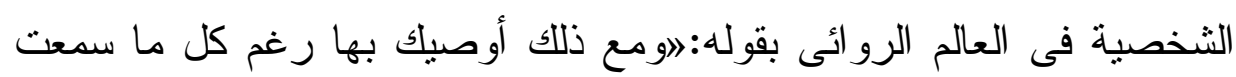
عنها، فقد عاشرتها ثلاثين سنة ولا أحب أن أخاصم أحدًا (r) يمكن تأويله فى ضوء المؤشر ات السياقية لثورة 0ب يناير ، وخطاب التتحى.

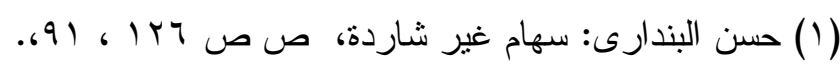

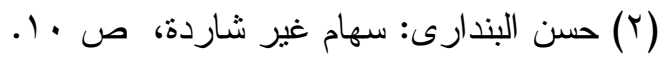

$$
\begin{aligned}
& \text {-ᄉrr- }
\end{aligned}
$$


وتتضافر الإحالات الزمنية فى تعالق الخطابين السردى و السياسى، منتقلة

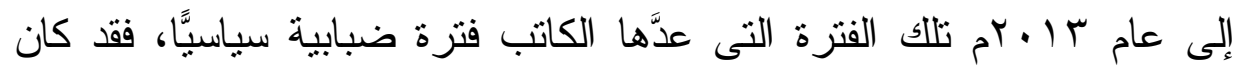

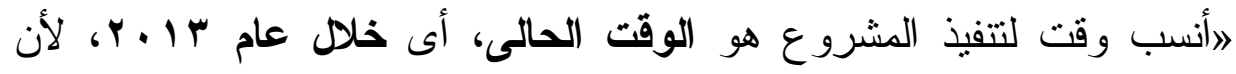

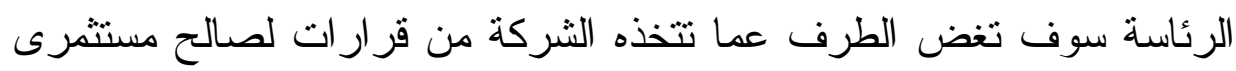

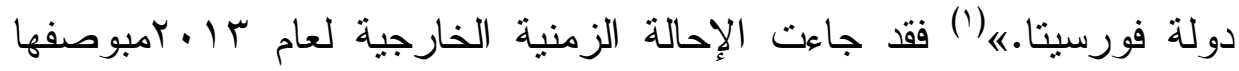

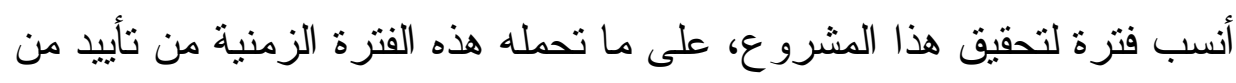

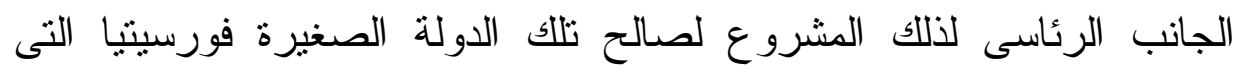

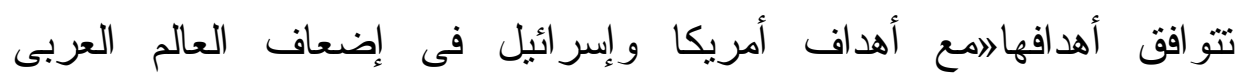

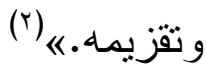

وفى تلك الفترة الزمنية أيضًا يثير الكاتب إلى أحداث روائية تعد معادلاً

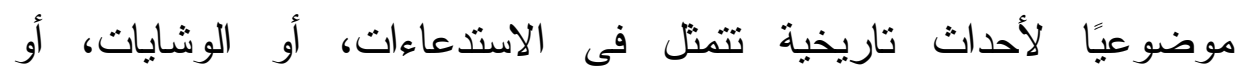

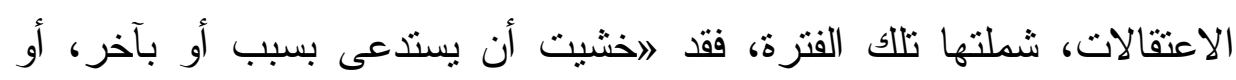

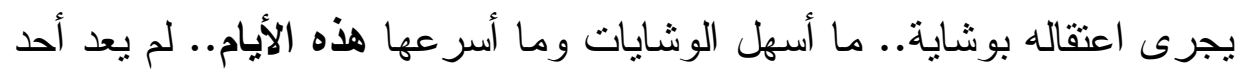

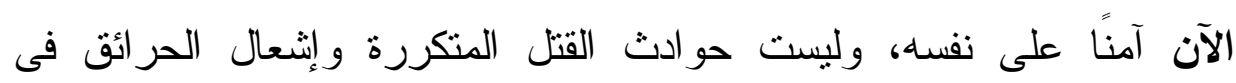
السيار ات و المؤسسات ببعيدة عن العين المتابعة المهومة. كيف ولئن يمكن مواجهة

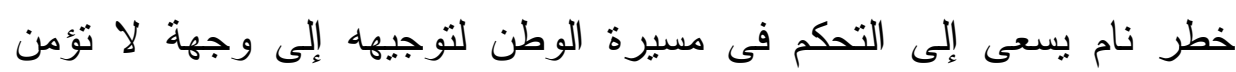

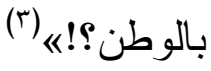

كما تتمنل تلك الأحداث التاريخية فى عمليات الإطاحة بعدد من القوات

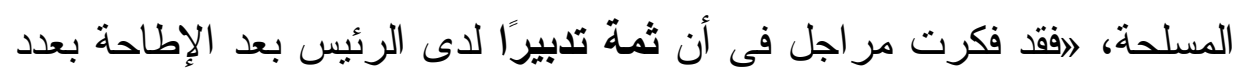

$$
\begin{aligned}
& \text { (1) المصدر السابق، ص سبا. }
\end{aligned}
$$

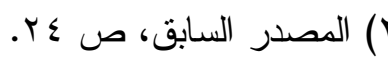

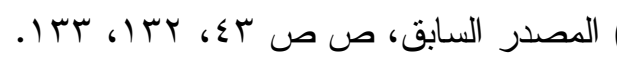

$$
\begin{aligned}
& -\wedge r \varepsilon-
\end{aligned}
$$




\section{دـ · عزة شبل محمد}

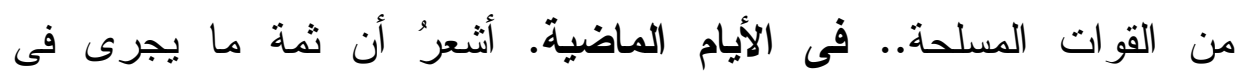

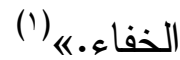

فقد استخدم الكاتب الثخصية الروائية للإحالة إلى الخطاب السياسى، وهو ما نر اه أيضًا فى الإحالة إلى فترة زمنية حرجة وهى فترة ما قبل الانتخابات الرئاسية، حيث حاول البعض إثارة الفوضى و التخريب. فجاءت الإحالة على هذه الفتزة الزمنية فى الرواية مرتبطة بوجود العملاء الخائنين للبلاد، فقد كان (سيف الجابرى) أحدهم و احضوره إلى القاهرة قبل انتخابات الرئاسة لمهمة لم تكن مريحة على الإطلاق: وهى تسليم أموال وجمع معلومات عن الموقف الاقتصادى ومواقع عسكرية فى رفح و العريش. ويمكن الاستعانة بعميل قريب

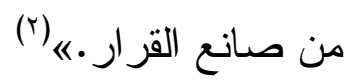
ويمزج الكاثب بين العالم الروائى والخطاب السياسى، من خلال الإحالة الزمنية على أحداث تاريخية حدثت بالفعل فى تلك الفترة،يمتلها حضور الرئيس الاحتفال السنوى بذكرى حرب أكتوبر 9 19 وسط محبيه و أنصار ه، فى الو اقع الخارجى، مشيرًا إلى شعور الزوجة الخائنة (مرجل الجابرى) بالر احة وهى تتابع هذا المشهد فى العالم الروائى، فقد كانت التشاهد فيلمًا تسجيليَّا عن الاحتفال بذكرى حرب Vr فى أستاذ القاهرة. تزى فى الفيلم الرئيس محمد مرسى يقف فى سيارة مكثوفة وسط تهليل أنصاره تشعر بالر احة وهى تتابع

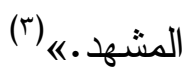

\section{ثـ الإحالة اللونية:}

استخدم الكاتب اللون فى بناء نوع متميز من الإحالة بمكن أن نطلق عليه

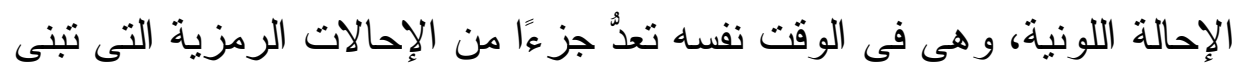

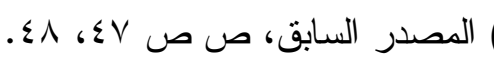

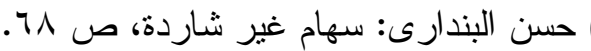

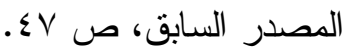


العالم الروائى. يعتمد بناء هذه الإحالة على مجيىء اللون صفة لمرجع ما، ثم

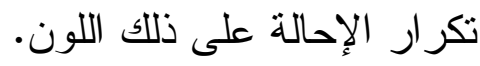

ويرتبط تثكيل الإحالة اللونية بأيديولوجية الكاتب، وبناء الفكرة الأساسية التى يدور حولها النص، ألا وهى الوقوف ضد من يريدون هدم الوطن وتخريبه

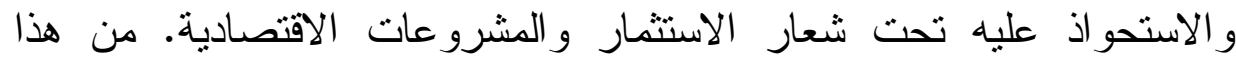

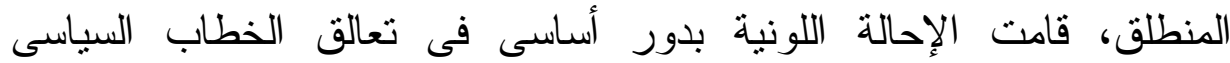

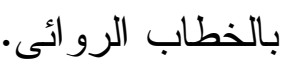
ففى العالم الرو ائى يحدد (حازم المنصورى) زمن وصوله إلى الوطن الذى غاب عنه ؛ لسفره خارج البلاد، وربط هذا الوقت بشهر (يونيو) الذى يحيل

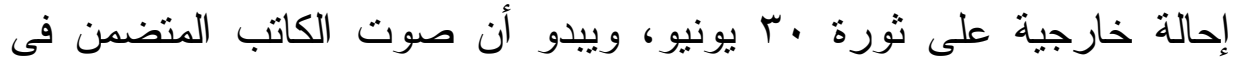
صوت الثخصية الروائية يؤيد تلك الثورة، ويحتفى بمجيأها؛ ويتجلى ذلك فى لثى وصفها بالثمس الساطعة النى بظهورها قضت على فترة الظلام السابقة عليها.

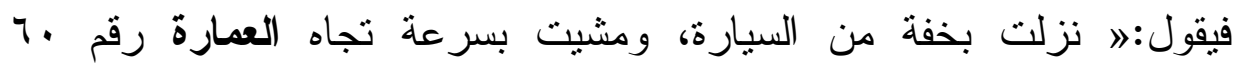
الرمادية تحت شمس يونيو الساطعة.ه) (1) تتضافر فى هذا المقطع السردى الذى يتصدر الرواية دلالات الإحالة

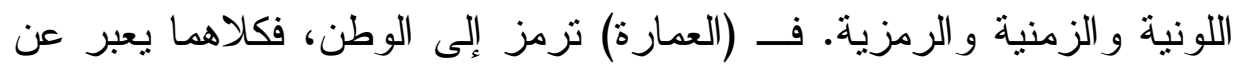

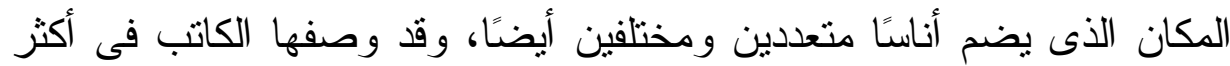

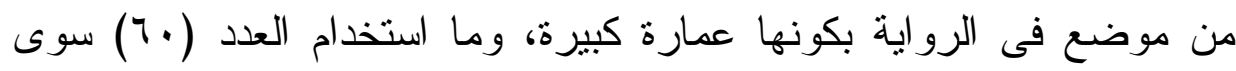

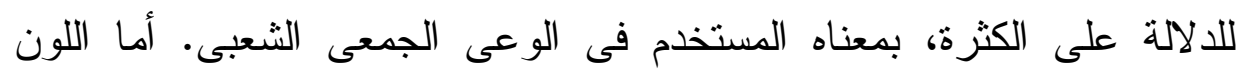

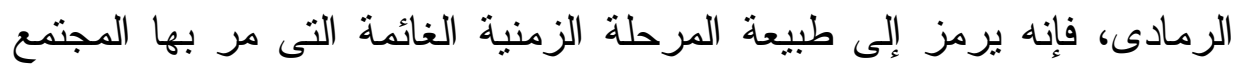
المصرى قبل ·ـ يونيو، و التى تغيرت بمجىء الثورة التى كثفت ذلك الغيام

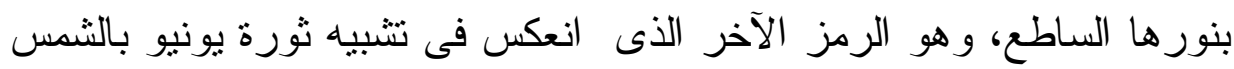




\section{دـ · عزة شبل محمد}

الساطعة. وهنا يتو ارى صوت المؤلف خلف صوت الشخصية الروائية ووصفها لشمس يونيو الساطعة، فرحًا بتلك الثورة مؤيدًا لها، ومعبرًا عن ذلك بخفة النزول، و المشى سريعًا.

وتتكرر الإحالة فى مقاطع أخرى من الحكى على اللون الأسود الذى يرمز

إلى أعداء الوطن، ويعبر عن رؤية الكاتب المستترة خلف شخصيات العمل الأدبى. فعند وصول (حازم المنصورى بهو العمارة يقول: اطالعتتى لوحة نحاسية كبيرة محفور فى وسطها باللون الأسود (المجموعة الهندسية للاستثمارات (الدولية).ی)(') يرمز اللون الأسود إلى ذلك الخطر المهدد للوطن المتمثل فى تلك الثركة التى أطلق عليها (المجموعة الهندسية للاستثمار ات الدولية). وقد اختار لها الكاتب تلاك التسمية بعناية فائقة. فالخطر الموجه نحو الوطن ليس خطرًا فرديَّا، و إنما هو متعدد المصادر متحد الهدف، وهو ما أنثار إليه بكلمة (مجموعة)، وبالصفتين (كبيرة)، و (دولية)، كما أنه خطر ممنهج مخطط له وعميق يضرب بجذور راسخة، وهو ما عبَّر عنه اختيار الصفتين (الهندسية)، و (محفور).

ونجد أن الكاتب قد استخدم تقنية الترادف بين الكلمات (الرمادى)،

و(الظلام)، و (الأسود)، لبناء دلالة تلك الإحالة التى ثزمز إلى حالة البلاد السيئة فى الفترة قبل ثورة يونيو والتى وصفها بكونها فترة زمنية ضبابية غائمة سياسيَّا،و عبر عنها بلون بين الأسود و الأبيض، هو اللون الرمادى، (وقة تسلل من زجاج مكتب رئاسة المجموعة لون رمادى (تقبض له صدرىه) لهان) وقد ״شعر بوحشة شديدة حينما رأى الظلام من زجاج النافذة.《(r)

$$
\begin{aligned}
& \text { (1) حسن البندارى: سهام غير شاردة، ص } 7 .
\end{aligned}
$$

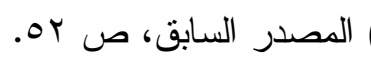

$$
\begin{aligned}
& \text { المصدر السابق، ص V^. }
\end{aligned}
$$


ج- الإحالات المتضادة:

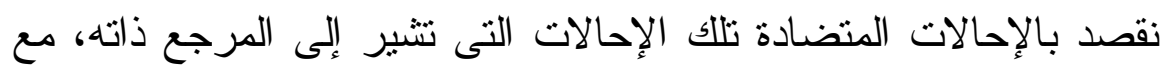

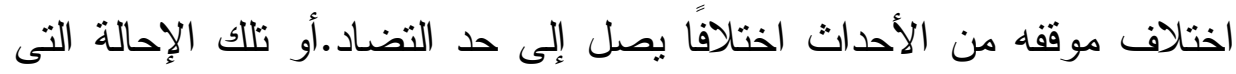
تثنير إلى مرجعين متضادين فى النص.

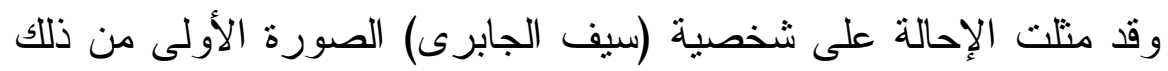
النوع. فهو عميل خائن بلاده، تسبب فى عمليات القتل و الترويع و التفجير بقوله:

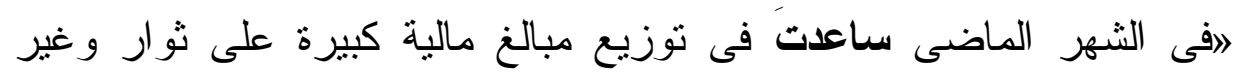

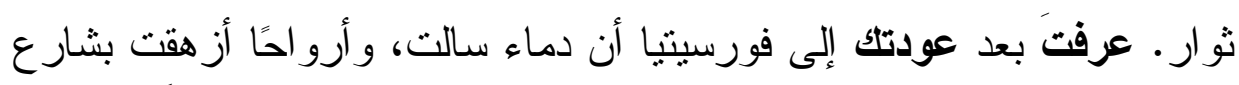

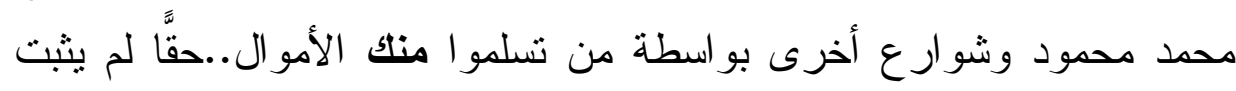

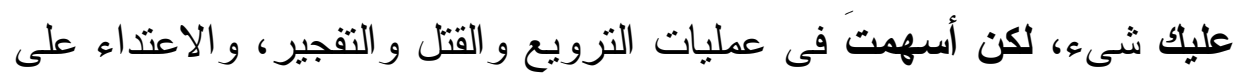

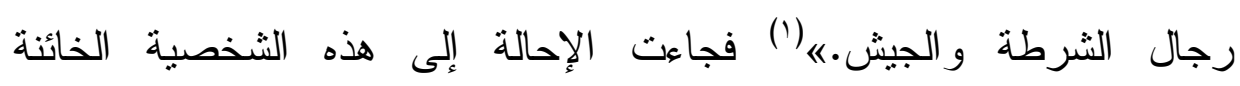

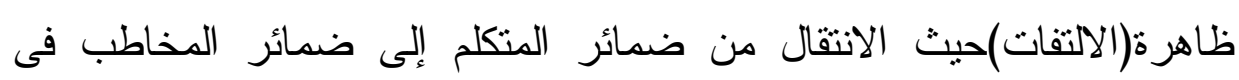

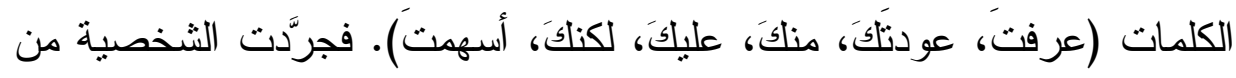
نفسها شخصًا آخر يخاطبها، مستخدمة تلك الظاهرة البلاغية.

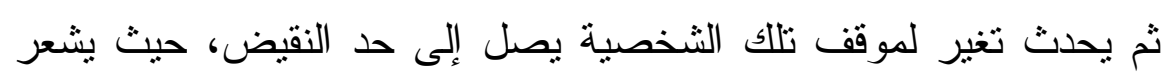

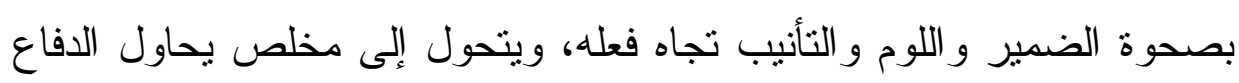
عن الوطن ضد هؤلاء الذين يريدون تدميره، مؤكدًا موقفه الر افض للخيانة

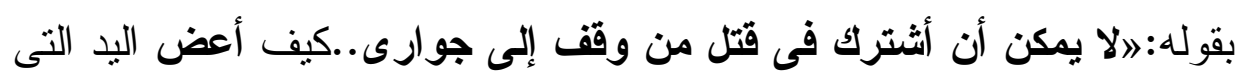

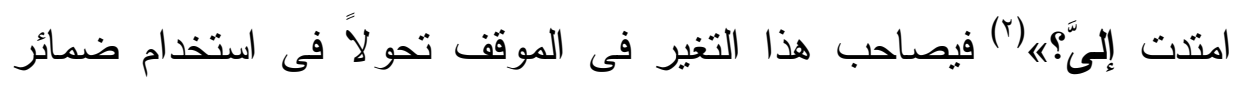
الإحالة، حيث تحل ضمائر المتكلم مع الكلمات:(أنشترك، جوارى، أعضُ، إلى لهَّ)

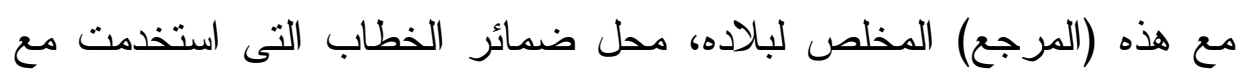

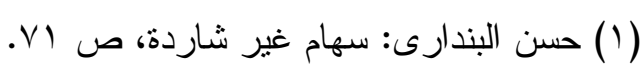

$$
\begin{aligned}
& \text { (Y) المصدر السابق، ص النيارئ } 10 .
\end{aligned}
$$




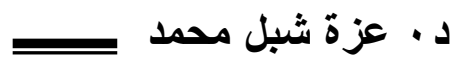

الإحالة المقابلة على (المرجع) الخائن. وقد ساهمت هذه الإحالة فى تعالق الخطاب السياسى بالخطاب الروائى من خلال التأكيد على وجود فكرة العميل

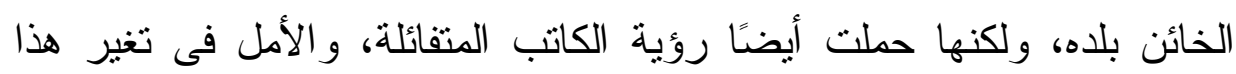
الفساد، بصحوة الضمير التى حدثت للثخصية، فانقلبت إلى الموقف المضاد. أما الصورة الأخرى من الإحالات الضدية، فهى تلك التى تعتمد فى بنائها على وجود مرجعين متضادين فى موقفها منقضية واحدة فى النص، كل منهما

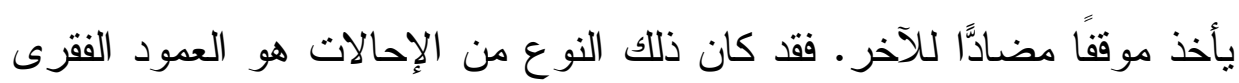

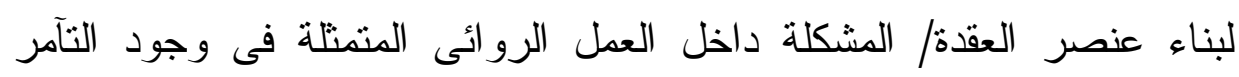
و العمل ضد مصلحة البلاد. فقد كانت قضية التآمر وخيانة الوطن قضيةً محوريةً بالدرجة الأولى فى الخطاب السياسى. يتجلى ذلك فى المقابلة الإحالية بين: صوت الثخصيات الخائنة التى تسعى لتدمير البلاد، ويمثلها الإحالة على لي شخصيات: الزوجة الخائنة (مر اجل الجابرى)، و أخيها العميل (سيف الجابرى)، و عشيقها (شوقى العياشى) رئيس مجلس إدارة شركة التقوى للأوراق المالية، ومهندس الثركة (سعفان الفرجانى)؛ وصوت الثخصيات المخلصة المحبة للوطن، ويمثلها الإحالة على شخصيات: (جمال المنصورى) صاحب المجموعة الهندسية، و أخيه (حازم المنصورى)، وابنه (عماد)، وزوجة سيف الجابرى (أسماء قبلان) السورية المحبة لمصر، وسكرتيرة المجموعة الهندسية(أنوار المو اردى)، ومديرة المنزل (صفية العايدى)، و العقيد المكلف بالحر اسة (مر اد (الجيوشى).

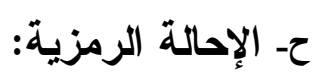

تعد الإحالة التى تعتمد فى بنائها على الرمز من أكثر الإحالات منفتحة الدلالة، على حسب تأويل القارئ لها، فى ضوء المعطيات السياقية داخل العمل

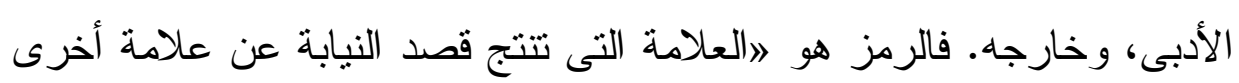




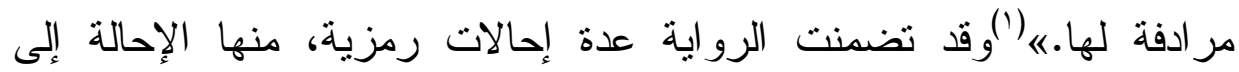

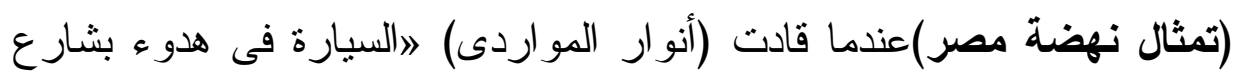

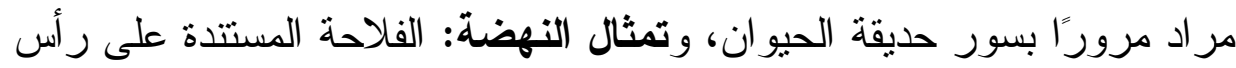

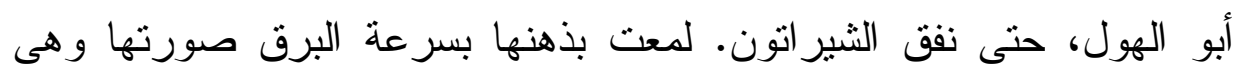

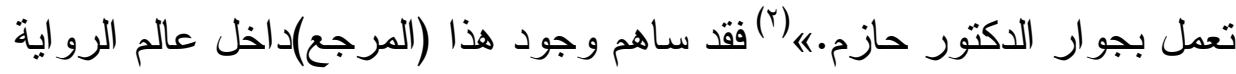

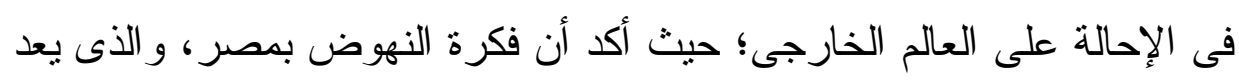
هذا التمثال رمزًا له، تعتمد على تعاون و إخلاص كلا النو عين الرجل الرجل و المر أة.

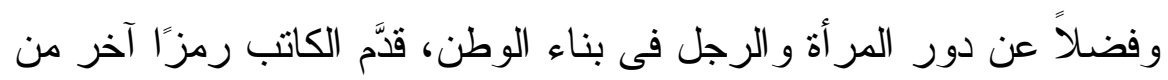

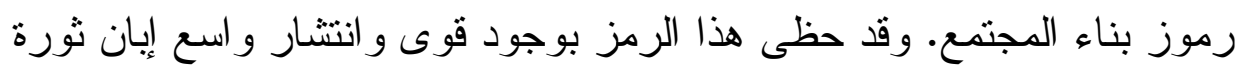

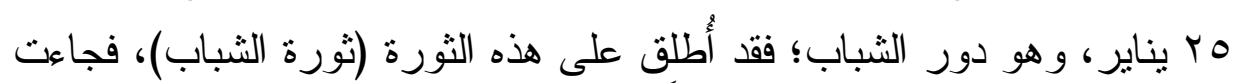

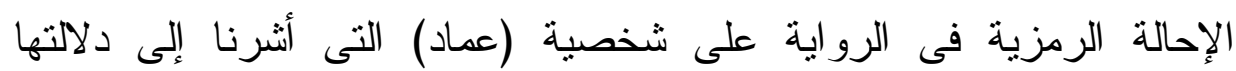
المعجمية الموحية بالاعتماد عليها فى بناء الوطن.

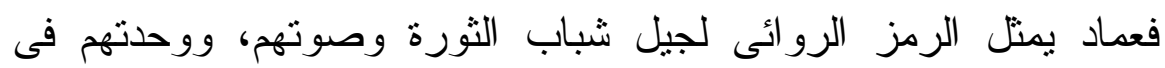

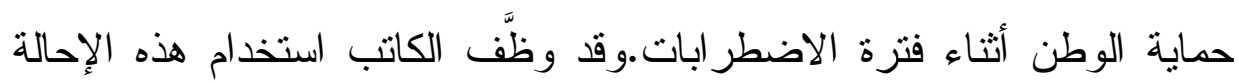

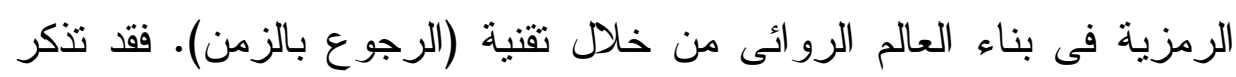

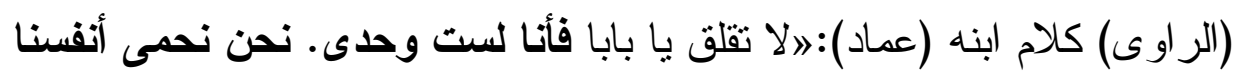
بأنفسنا..عدت إلى تذكر مشهر اعتداء الميلثيات المسلحة على خيام الثبان

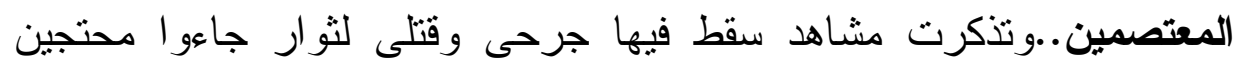

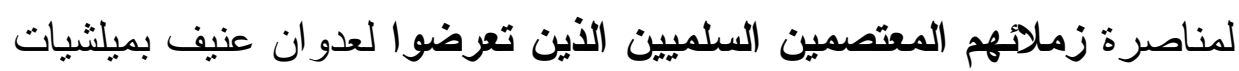
مدربة. ظهر العدوان الوحشى فى وسائل الإعلام المحلية و العربية و العالمية..

(1) محمد السرغينى: محاضرات فى السيميولوجيا، الدار البيضاء، دار النقافة، 9Av (1)، ص 


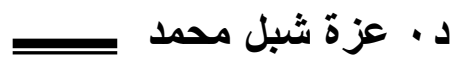

جرى ضرب بعض الثوار وخطفهم، وتسليمهم إلى الثرطة بوصفهم مثيرى

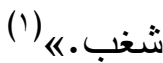

ونظرًا لكون هذه الإحالة ترمز للشباب، فقد كانت الضمائر الشخصية

المستخدمة فى بنائها هى ضمائر الجمع على نحو ما نجد فى الكلمات (نحن،

نحمى، أنفسنا بأنفسنا، تعرضوا، زملائهم، خطفهم، تسليمهم، وصفهم)، كما جاءت أيضًا الإحالة باستخدام الاسم الموصول الدال على الجمع (الذين)، وساهمت الوسائل اللغوية الأخرى فى تأكيد تلك الإحالة الرمزية الجمعية، كالتكر ار (أنفسنا بأنفسنا)، و الوصف (المعتصمين، السلميين، الثوار)، و التقرير و النفى (أنا لست وحدى).

وفى رؤية أكثر شمولية من الكاتب للوضع الخارجى العام للبلاد، قدّم

تصوره بأن تحقق أمن البلاد ليس رهنًا فقط على الأمن الداخلى، و إنما يرتبط أيضًا بالأمن القومى؛ لذا جاءت الإحالة إلى مرجع (أسماء قبانان) السورية يرمز إلى الوحدة الوطنية بين مصر وسوريا، فهى التعثق نز اب مصر ، ودائما توصينى بها. كم سمعتها تقول لى مصر وطنى الأول مثل سوريا وطنى الأول. لا يمكن أن يشارك سورى فى إيذاء مصرى، كما لا يمكن أن يعتدى مصرى على سورى، فهما معًا فى قارب و واحد، وجناحا المحافظة على وحدة العرب.«") فقد أكدت الإحالة بالضمائر الثخصية الأو اصر التى نزبط البلدين

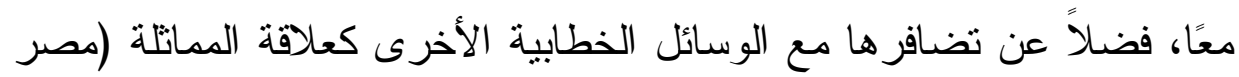

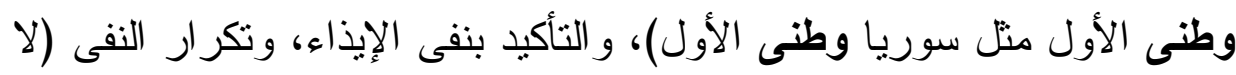
يمكن أن يشارك سورى فى إيذاء مصرى، كما لا يمكن أن يعتدى مصرى على الهى سورى)، واستخدام الجملة الخبرية التقريرية لمعنى الوحدة العربية (فهما معًا 
فى قارب واحد، وجناحا المحافظة على وحدة العرب)، فأصبحت هذه الإحالة رمزًا للوحدة القومية بين مصر وسوريا.

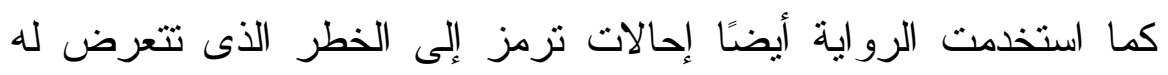

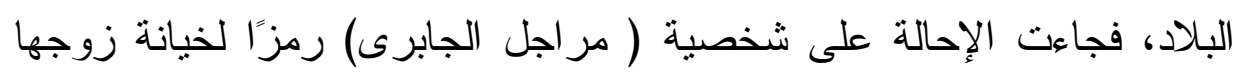

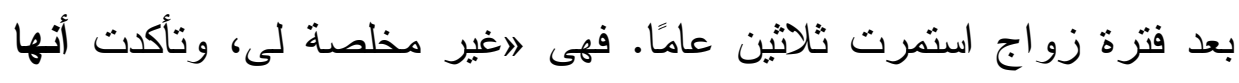

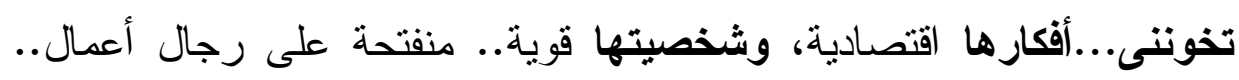
تؤيد المشروع وتوافق على البيع للجانب الفورسيتى.. تستعجل موت جمال

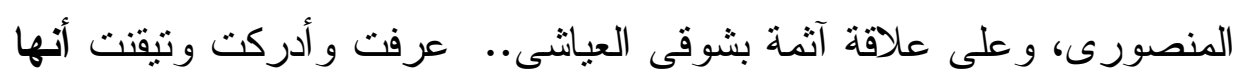
خطر عليك.《) (ل) وقد أسهوت الإحالة بالضمائر الثخصية فى الكلمات (أنها، تخوننى،

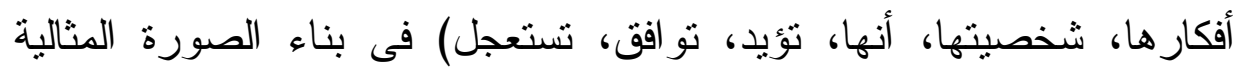

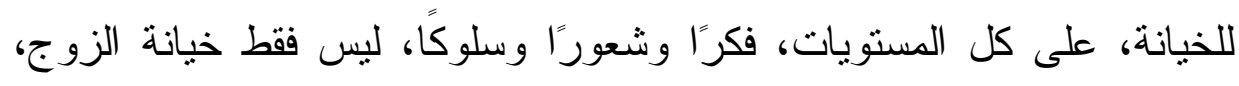
و إنما أيضًا خيانة الوطن الذى تريد بيعه.

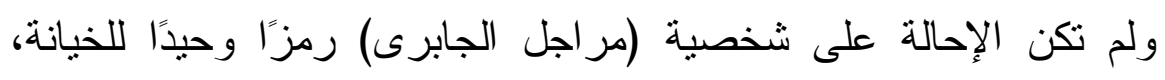

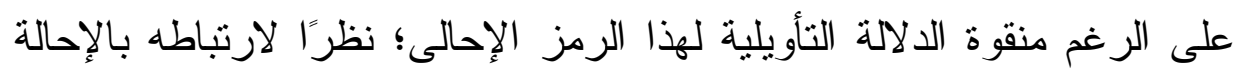

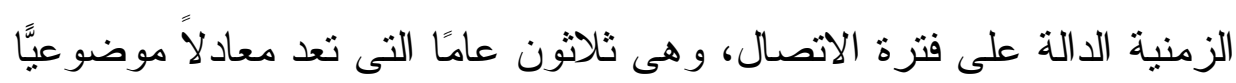

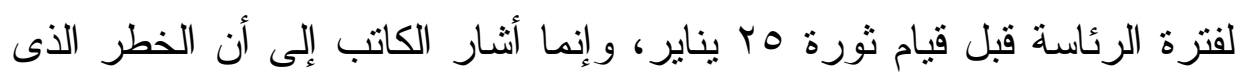

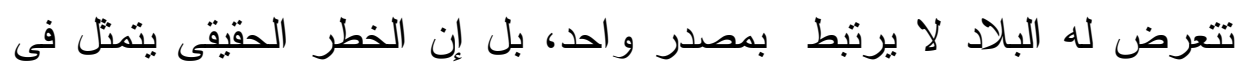

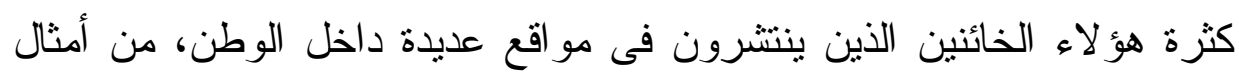

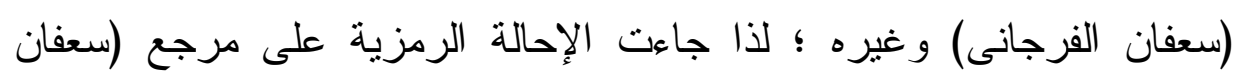

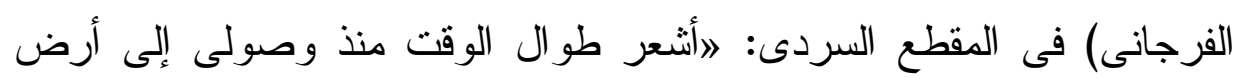

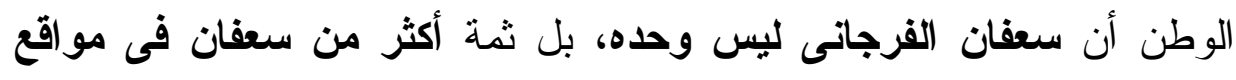


د.

عدة."(')تخذة من تكرار الاسم (سعفان) موازيًا لغويَّا لتكرار عملية الخيانة،

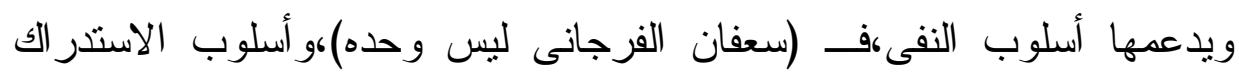
للتأكيد على وجود أكثر من خائن فى أكثر من مكان، (بل ثمة أكثر من سعفان فى مو اقع عدة). شذرات الخطاب السياسى فى البنية الروائية: الإحالة ومقصدية المؤلف فى الخطاب:

إن الإحالة عملية تو اصل تقتضى التفاعل بين أطر اف العملية التو اصلية، فـ»العمل الإحالى الذى يقتضى تعيين شىء محال عليه بواسطة عبارة تسمى عبارة إحالية، ولكن هذه العبارة ليست هى التى تحيل، و إنما الذى يحيل هو المتكلم الذى يستعمل هذه العبارة بقصد الإشارة إلى الموضوع المحال عليه، و هذا يعنى ألا وجود للمرجع إلا متلبسًا بقصدية المتكلم مستعملاً للغة، محولاً

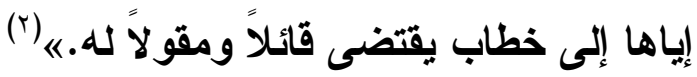
وفى ضوء العلاقة التفاعلية بين الخطاب الأدبى وطرفى عملية التو اصل: المبدع و المتلقى، تؤدى الإحالة عدة وظائف تواصلية تبعًا لمقاصد المبدع المباشرة، أو غير المباشرة التى تستتر وراء القيمة الجمالية و البناء الفنى للعمل الأدبى. وبعد تحليل نظام الإحالة فى رواية (سهام غير شاردة) و أنماطها، يمكننا الكثف عن هذه الوظائف التواصلية. فعلى الرغم من أن الإحالة وسيلة من الإن وسائل الربط النحوى و الدلالى بين الجمل فى الرواية، فإنها تمنل وسيلة بناء أساسية للعناصر الروائية فى الخطاب السردى: الشخصيات، و الأحداث،

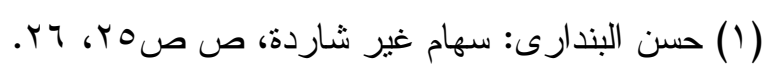

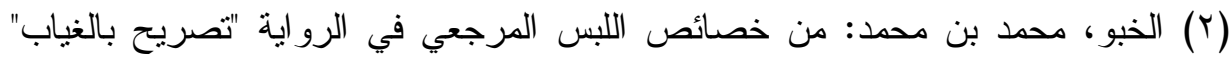

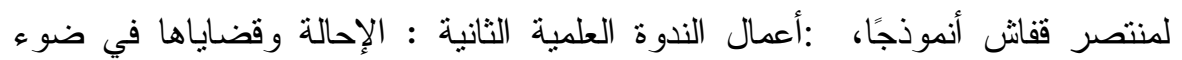
المقاربات اللسانية و التداولية - كلية الآداب و العلوم الإنسانية - جامعة القيروان -

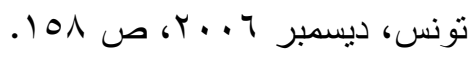




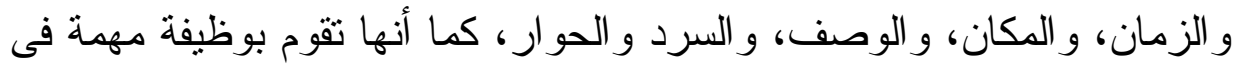

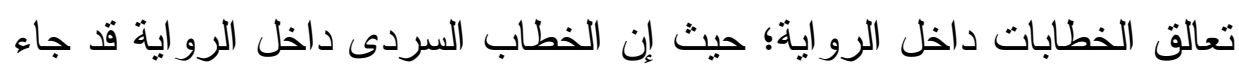
محملاً بخطابات سياسية كثفت عنها أنماط الإحالات النصية الدابل الخلية

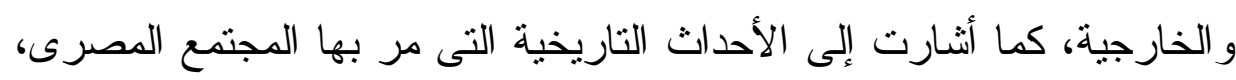
وعرضها المبدع من خلال تفاعل الثخصيات و الأحداث داخل العمل الروائى.

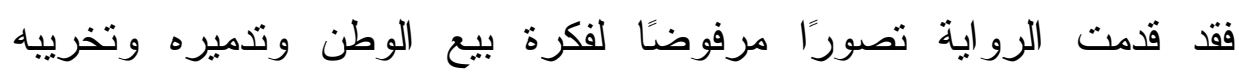
و استعمار ه تحت مظلة التعمير و المشرو عات الاقتصادية الو همية.

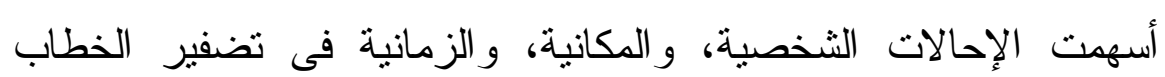
السياسى بالخطاب الرو ائى، من خلال أدو ات الربط السردية، كالأفعال (تذكرت، الزئ،

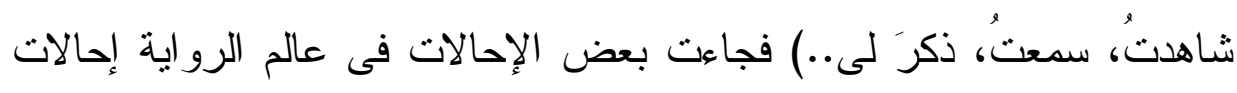

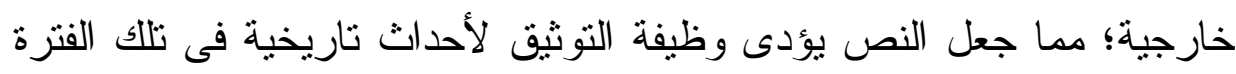

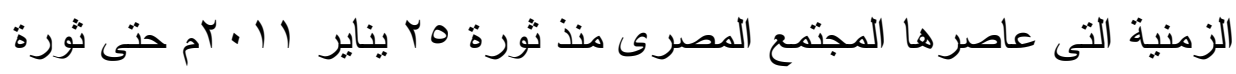

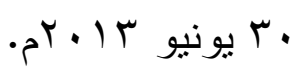

رسمت هذه الإحالات الخارجية صورة الموقف من النظام،و المظاهرات،

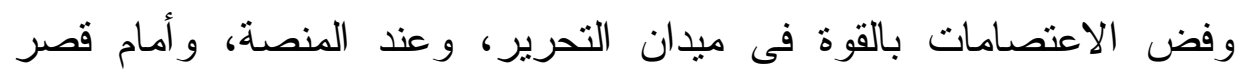

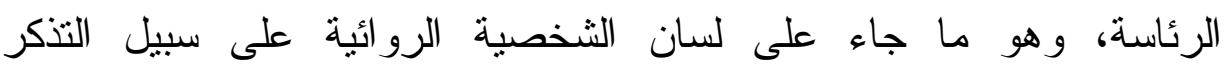

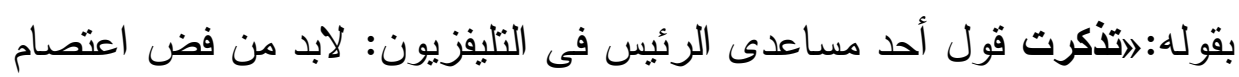

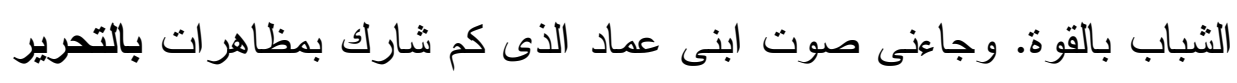

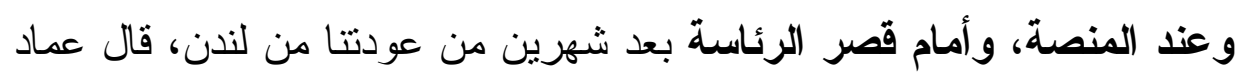

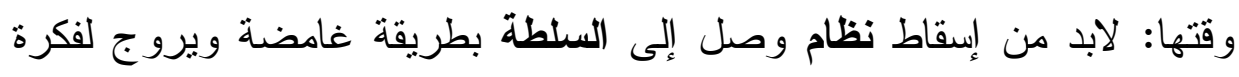

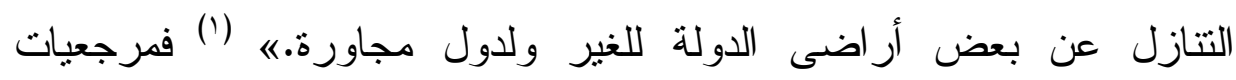

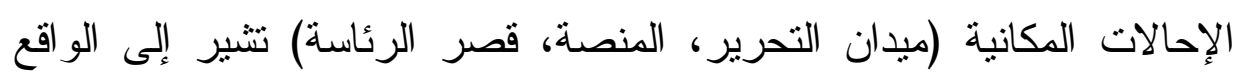




\section{د.}

الخارجى، خاصة أن الكاتب ربط بين هذه الأماكن و الأحداث الفعلية التى حدثت بها فنزة الثورة.

ويدعم ذلك التأويل إثنارة الكاتب إلى حالة الفوضى و التخريب التى عمت

البلاد فى تلك الفترة: لهل يستمر العفو والتسامح رغم تدفق الدولارات على أثخاص يعمدون إلى التحريض على القتل والتدمير؟..قتل أبناء وطنى وتدمير ممتلكاته ومؤسساته الحكومية وغير الحكومية لإثـاعة الفوضى."(')هنا إحالات خارجية على شخصيات أبناء الوطن، وتعرضهم للقتل على أبدى أثخاص مأجورين تتدفق عليهم الأموال من الخارج. وكذلك الإحالات المكانية إلى المؤسسات الحكومية وغير الحكومية التى تعرضت للحرق و التثمير • وليس يخفى عن المتلقى الإحالات المكانية المسكوت عنها فى هذا المقطع السردى كحرق المجمع العلمى، ومجلس الثعب، و أقسام الثرطة، وغير ها من المنشئات بغرض إثثاعة الفوضى و التخريب. ولم تقتصر الإحالات الخارجية المكانية على التوثيق لحرق بعض الأماكن فى مصر، و إنما ارتبطت أيضًا بقضية قتل الثوار فى بعض أماكن الاعتصامات، فتعالقت الإحالة المكانية مع الإحالة إلى مرجع (قتلة الثوار) فنرى الشخصية الروائية تقول:»عندى أقوال وأفكار سأطرحها على النائب العام اتهم بها قتلة الثوار فى شارع مجلس الشعب والشورى، وشارع محمد محمود، وأمام قصر الاتحادية، وميدان عبد المنعم رياض.ب(؟) وقد حاول الكاتب الإشارة إلى بعض الأحداث الحقيقية التى كانت معانشة فى المجتمع المصرى فى تللك الفترة، فقدَّم بعض صور الوقيعة و التشتت التى لـى حدثت بين فئات المجتمع المصرى، من خلال الإحالة الثنصية على مر اجع

$$
\text { (1) المصدر السابق، ص هr. }
$$


خارجية هى (الطلاب، الأساتذة، الثوار، الجيش، الثرطة، القضاء)؛ حيث 》الصدام قد بدأ يقع بين طلاب الجامعة بعضهم البعض..ثمة من يحاول دائمًا

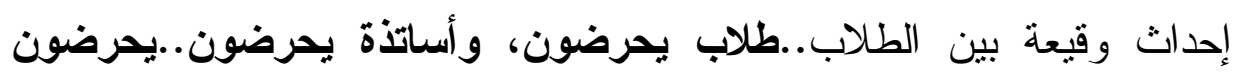

على الثوار، وعلى الكبار، وعلى الأساتذة والجيش والثرطة و القضاء.به (1)

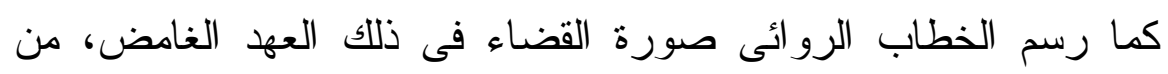

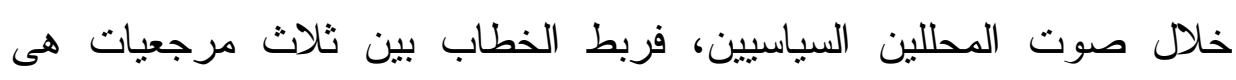

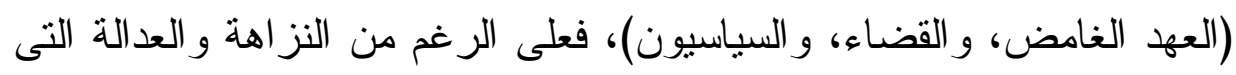

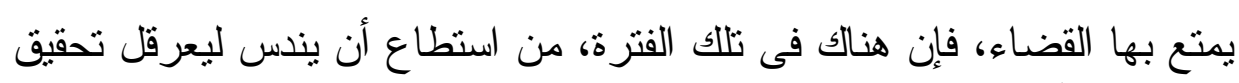

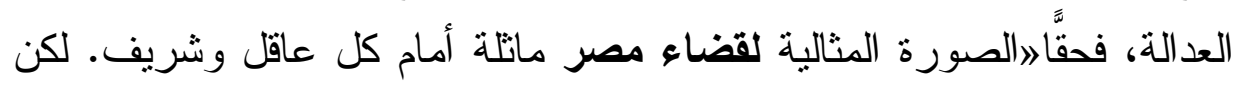

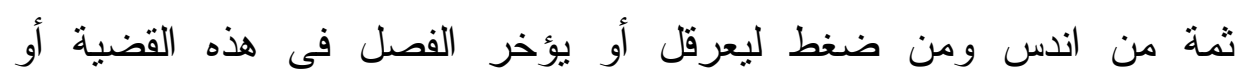

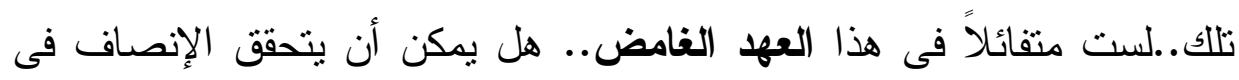

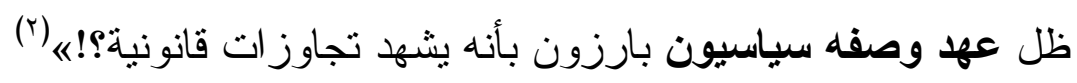

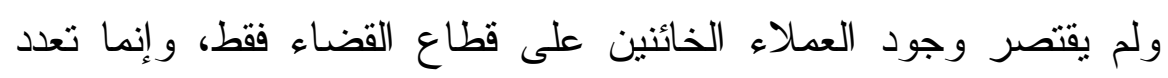
وجودهم فى قطاعات أخرى عديدة بالبلاد. فجاء ارتباط الإحالة الثخصية إلى لى لئل

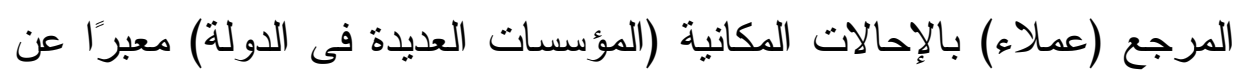

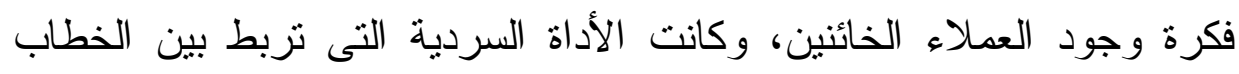

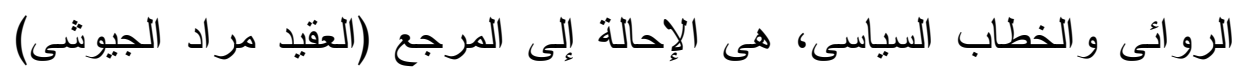

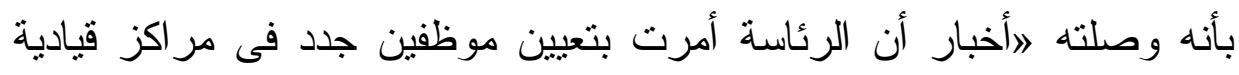
بمؤسسات عديدة فى الدولة، مثل: الكهرباء والمياه والبترول والخارجية والأمن الوطنى")

$$
\begin{aligned}
& \text { (1) المصدر السابق، ص بعـ. (Y) }
\end{aligned}
$$

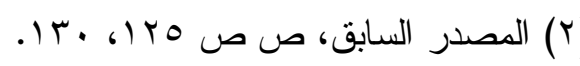

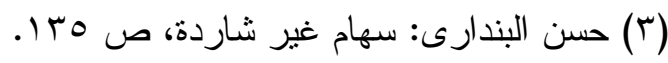

$$
\begin{aligned}
& -\wedge \leq 7-
\end{aligned}
$$




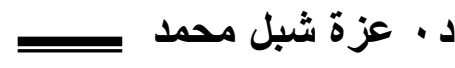

وينتقل بنا الخطاب السياسى إلى مرحلة ما الفوضى والتخريب، وهى مرحلة انتخابات البرلمان، وانتخابات الرئيس فجاءت الإحالة على هذين المرجعين كاثنفةً عن موقف البعض منهما، فـ»انتخاب برلمان وانتخاب رئيس. نظام حكم فرحت' به و أيدتُه وتحمست' له.. وكنت 'أصدق' أن ديمقر اطية حقيقية ستحكم وطنى..لكن ما لبثت الوقائع الصادمة المحكومة بأغر اض أن (أفقدتى حماستى وتأييدى" (1) و استكمالاً للمشهر السياسى العام، لم يكتف الكاتب بالحديث عن الثأن الاخلى للبلاد فقط، وإنما حاول تقديم إيديولوجيته الخاصة بتقسير الوضع الداخلى، وربطه بالمؤامرات التى تدبر ها بعض الدول للإطاحة بأمن واستقرار البلاد، و المسارعة بتطوعها فى فض المنازعات الإقليمية و الدولية لصالح أمريكا. وقد تمنل ذلك من خلال الإحالة على المرجع الرمزى الخارجى لدولة (فورسيتيا) والتى أثنار الكاتب فى مواضع عديدة من الرواية أن أمريكا تدعمهاءو اهذا يفسر سلسلة المؤتمرات و الندوات بفورسيتيا فى السنوات الأخيرة، و المسارعة إلى إبداء التطوع لفض منازعات إقليمية ودولية. وقد ظهر هدف ذلك لعدد من المتابعين وهو أن هذه الدولة بهذا التطوع ستكون عينًا

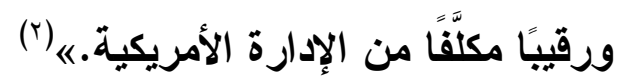
بعد هذا العرض التفصيلى الذى قدَّمه الكاتب عن الوضع الداخلى و الخارجى للبلاد، يصل الخطاب السياسى إلى بيان حالة الثعب المصرى. فتضافرت الإحالات المكانية، و الزمانية، والثخصية فى التعبير عن الوضع

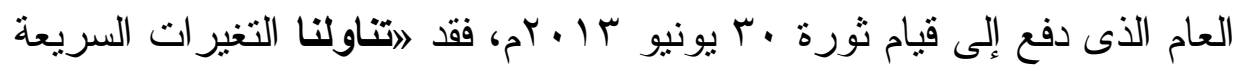
التى جعلت قطاعات و اسعة من الثعب تزداد قلقًا على قلق، ويأسًا على يأس،

$$
\begin{aligned}
& \text { (1) المصدر السابق، ص هץ ا. } \\
& \text { (Y) المصدر السابق، ص } 17 .
\end{aligned}
$$




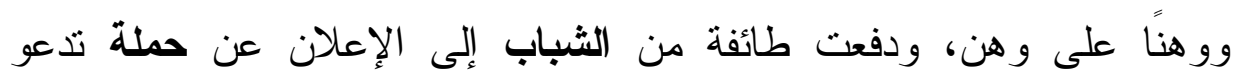

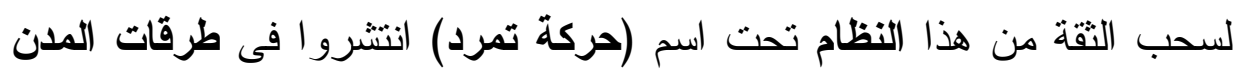

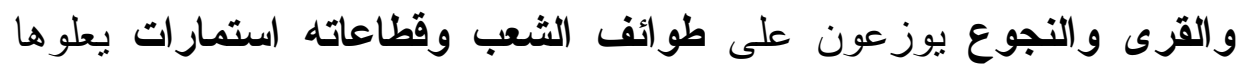
عنوان تمرد لسحب الثقة من النظام وتحت العنوان عنو ان آخر هو سحب النو الثقة

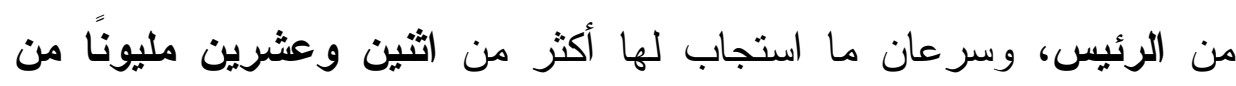

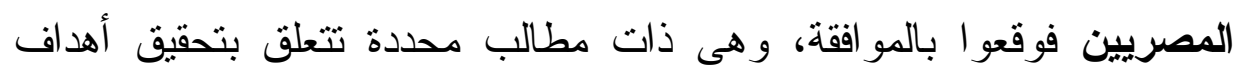

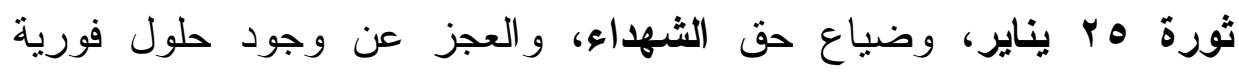

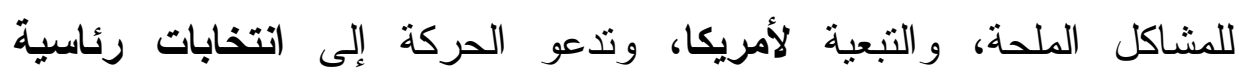

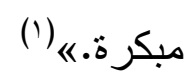

فجاءت الإحالات الثخصية إلى (الثباب) للإعلان عن حملة تدعو إلى الى الثاء

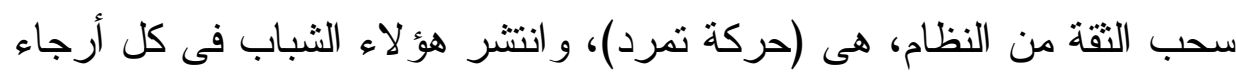

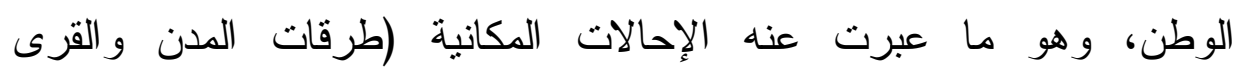
و النجوع)، فاستجاب لها عدد من المصريين، وكانت عالتهالت مطالب هذه المرجعية

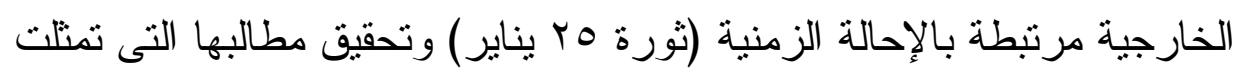
فى إدخال مراجع جديدة إلى عالم الخطاب السياسى، تمثلت فى (الثهداء) و المطالبة بحقهم، و(أمريكا) و إلغاء التبعية لها، و وانتخابات رئاسية مبكرة) و الدعوة إليها. تعددت تلك الثذرات الخطابية المشكّة للخطاب السياسى داخل العالم

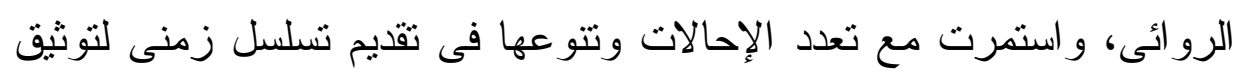

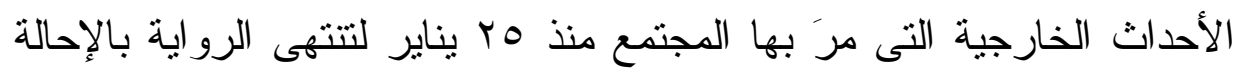

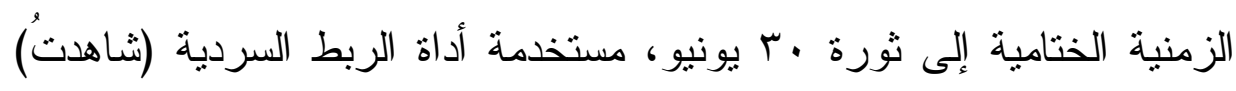

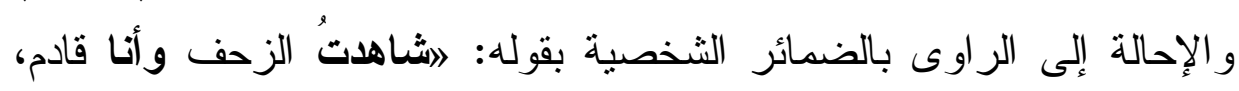




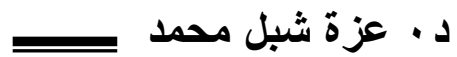

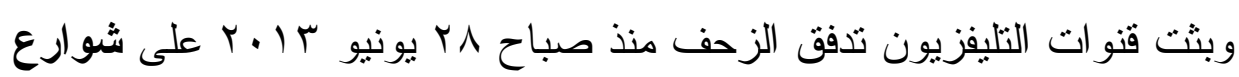
وميادين المدن، والقرى، والنجوع. تجأر أصوات الزاحفين وتتادى منذ صباح اليوم · ب يونيو بسقوط النظام، ورحيل الرئيس، كما تلعو أصواتهم إلى ضرورة استجابة القوات المسلحة لإرادة الشعب فى إرساء خارطة طريق

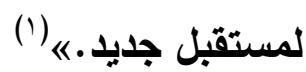

فتضافرت الإحالة الزمنية (صباح يوم ، ب يونيو) مع الإحالات المكانية

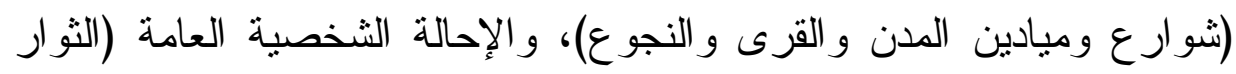

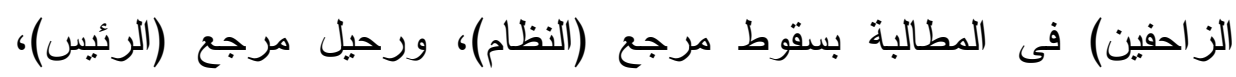
وضرورة استجابة مرجع (القوات المسلحة) لإر ادة (الشعب) فى إدارة البلاد. نتائج الدر اسةة: أسهمت در اسة دور الإحالة فى تعالق الخطاب السياسى بالخطاب السردى فى رواية (سهام غير شاردة) عن مجموعة من النتائج، هى:

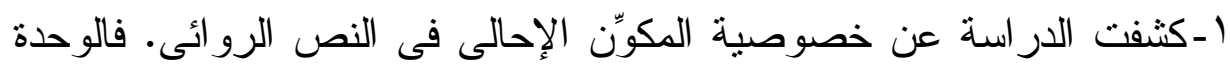
الإحالية السردية تتكون من عنصرين أساسيين، هما بؤرة الإحالة، وهو الإهو

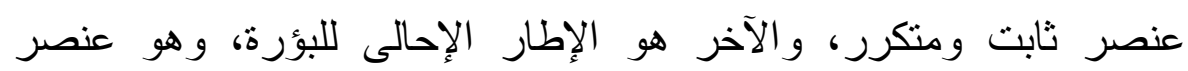

$$
\text { متغير على مدار الرواية. }
$$

r- أوضحت الدراسة طبيعة المرجعية فى النصوص السردية، بكونها مرجعية غير إحالية؛ فليس لها وجود فى العالم الخارجى، و إنما تكتسب تصور ها من البناء التخييلى الذى بنشؤه المبدع. r-تعتمد الإحالة فى بناء مرجعيتها على عملية التمثيل الذهنى لها، التى يمكن تصور ها فى العو الم الفعلية، أو العوالم المحتملة أو العو الم الممكنة، فليس هناك ربط مباثر بين الرموز الإحالية المستخدمة و المرجعية الخارجية.

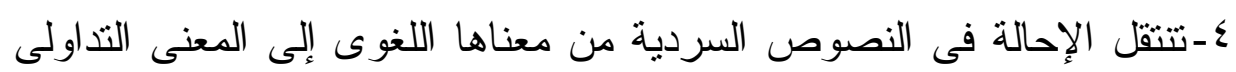

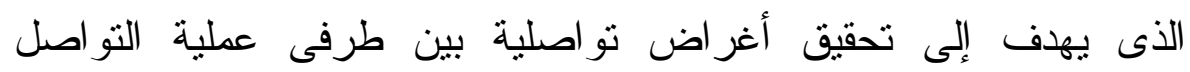


(الكاتب، و القارئ). فالمكون الإحالى لا يؤدى فقط وظائف تركيبية داخل دالئ

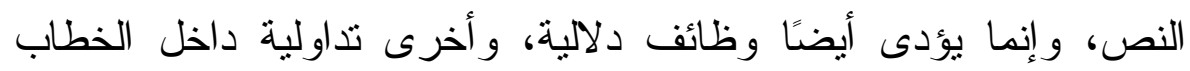

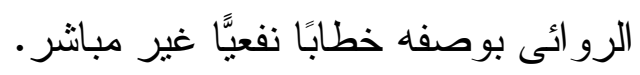

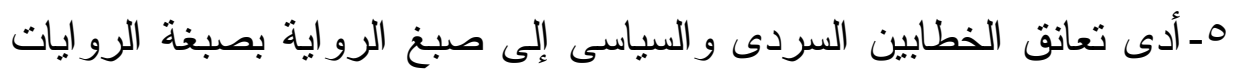

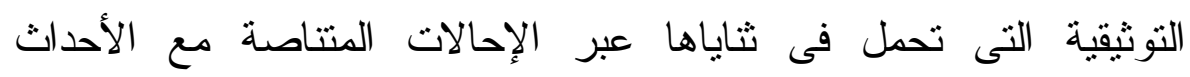

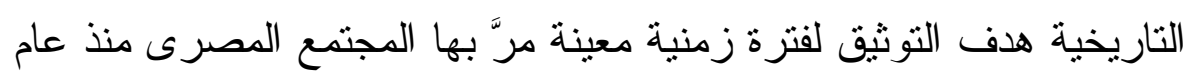

$$
\text { T } 11
$$

7-تعددت أدوات الإحالة النى تسهم فى تحقيق بناء الرواية وتماسكها، وتعالق الخطاب السياسى بالخطاب السردى، فكانت الضمائر الثخصية للمتكلم

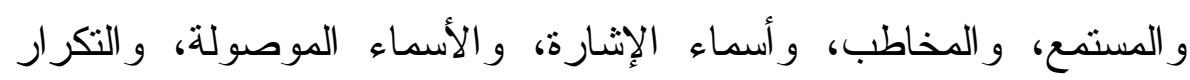

$$
\text { المباشر للمرجع أبرز هذه الأدوات. }
$$

V- أوضحت الدر اسة دور تر اتب الإحالة فى بناء العناصر السردية فى الرواتية:

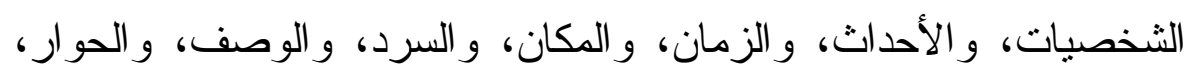

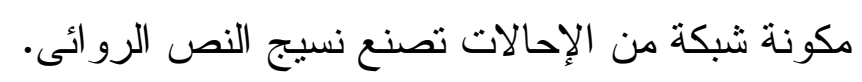

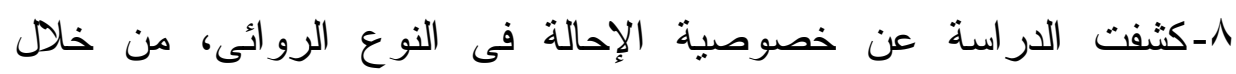

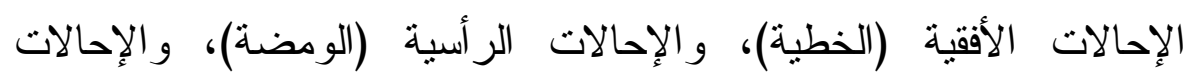
المتصلة، و الإحالات المنفصلة، و الإحالات التكر ارية، و عنقودية الإحالات.

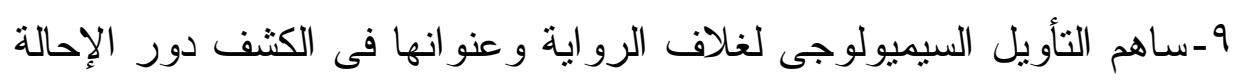
فى بناء الفكرة الأساسية و إيديولوجية الكاتب.

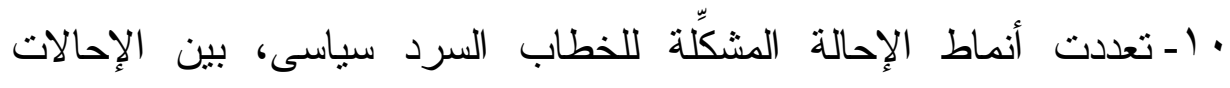

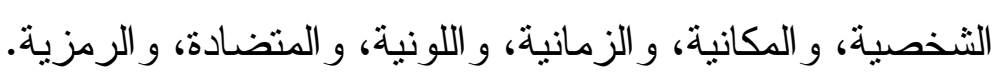

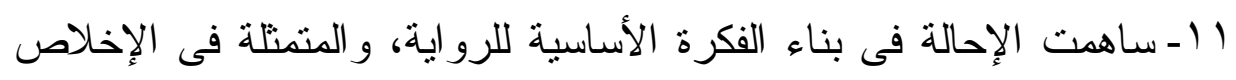
للوطن و التضحية من أجله، ورفض أى أذى قد يلحق به. 
د · · عزة شبل محمد

قائمة المصادر و المراجع:

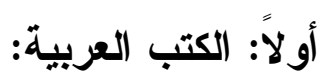

- الأزهر الزناد : نسيج النص (بحث فى ما بكون به الملفوظ نصًّا).

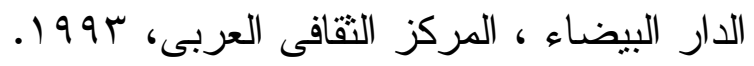

-حافظ إسماعيلى علوى وآخرون: تساؤلات التذاولية وتحليل الخطاب، در اسات وبحوث مختارة، ترجمة وتتسيق، عمان، دار كنوز المعرفة للنشر

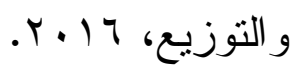

- حسن البندارى: سهام غير شاردة، طب القاهرة، مكتبة الأنجلو، YV . P. -سعيد يقين: التفاعل النصى والتزابط النصى بين نظرية النص و الإعلاميات، جامعة محمد الخامس، منشور ات كلية الآداب و العلوم الإنسانية

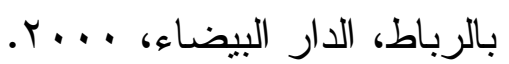

-صابر الحباثة: قضايا فى السيمياء و الدلالة، عمان، دار كنوز المعرفة للنشر

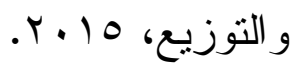

-صبحى إبر اهيم الفقى : علم اللغة النصى بين النظرية و التطبيق (دراسة تطبيقية على السور (المكية) ج r، القاهرة ، دار قباء للطباعة و النشر

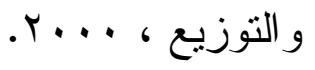

- عزوز على إسماعيل: عتبات النص فى الرواية العربية- در اسة سيميولوجية

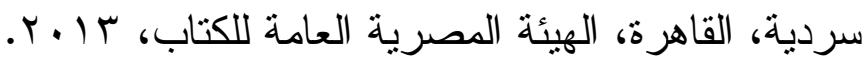
-محمد بازى: صناعة الخطاب، الأنساق العميقة للتأويلية العربية، عمان، دار كنوز المعرفة للنشر و التوزيع، 10 ـ ب. - محمد بن محمد الخبو: من خصائص اللبس المرجعى فى الرواية "تصريح بالغياب" لمنتصر قفاش أنموذجًا،أعمال الندوة العلمية الثانية: الإحالة وقضاياها فى ضوء المقاربات اللسانية والتداولية - كلية الآداب و العلوم الإنسانية جامعة القيروان - تونس، ديسمبر 7 . . T. 
- محمد رجب الوزير و آخرون: رؤى لغوية كاثفة عن الإبداع القصصى عند

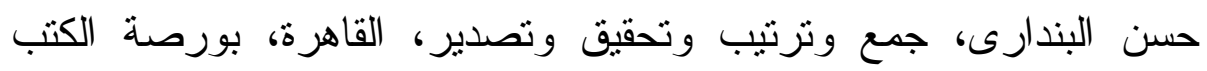

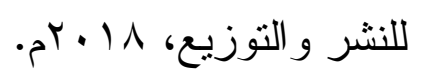

- محمد السرغينى: محاضرات فى السيميولوجيا، الدار البيضاء، دار الثقافة، $.19 \mathrm{NV}$

- محمد العنوز: تفاعل الأدب و التكنولوجيا، نصوص الواقعية الرقمية لمحمد

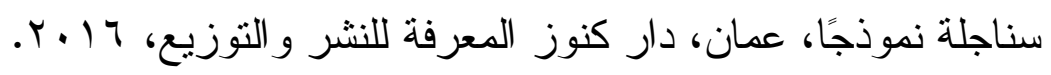

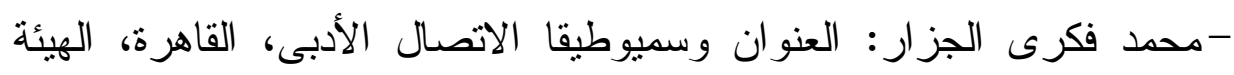

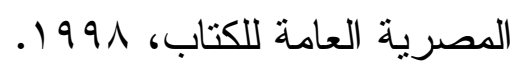

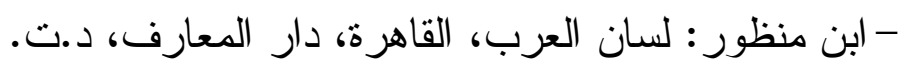

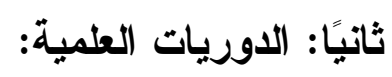
- خليفة عوشاش: المرجع و الإحالة فى النص الرو ائى، مجلة الممارسات اللغوية

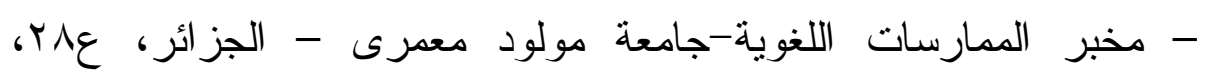
$. r \cdot 1 \leq$

- فايز أحمد محمد الكومى: تحليل البنية النصية من منظور علم لغة النص :

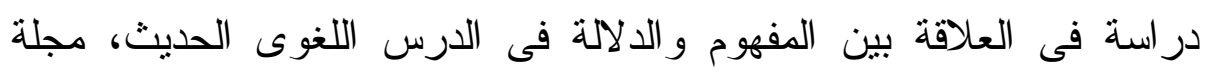

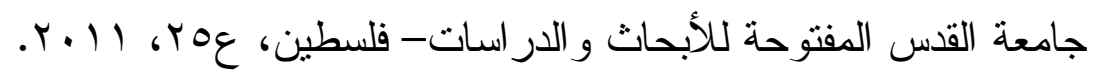

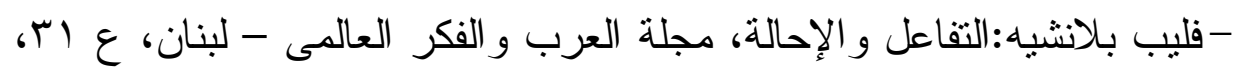

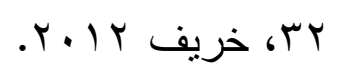
- محمد الأمين مصدق:الإحالة فى ضوء بلى علم اللغة النصى، مجلة اللغة العربية

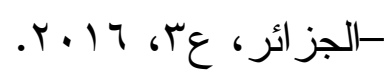


ב د · مزة شبل محمد

-يوسف محمود محمد الحسنى: الربط وأثزه فى البناء النصى، دراسة نحوية

دلالية، مجلة الأكاديمية الأمريكية العربية (أمار اباك)- الولايات المتحدة

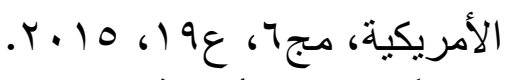

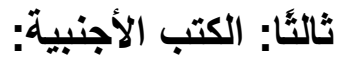

- Halliday \& Hasan : Cohesion in English . London, Longman, $19 \vee 7$.

- Raphael Salkie : Text and discourse analysis. Routledge, London and Newyork, 1990 . 